Foraminifera from the

Pierre Shale (Upper

Cretaceous) at Red Bird,

Wyoming

GEOLOGIGAL SURVEY PROFESSIONAL PAPER 393-C

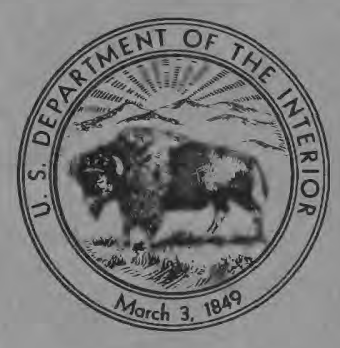




\section{Foraminifera from the}

\section{Pierre Shale (Upper}

\section{Cretaceous) at Red Bird,}

\section{Wyoming}

By JAMES F. MELLO

STRATIGRAPHY, PALEONTOLOGY, AND SEDIMENTATION OF A CLASSIC REFERENCE LOCALITY OF THE PIERRE SHALE

GEOLOGICAL SURVEY PROFESSIONAL PAPER 393-C

Sixty-one foraminiferal taxa are described from the complete section of the Pierre Shale at Red Bird, Wyo.

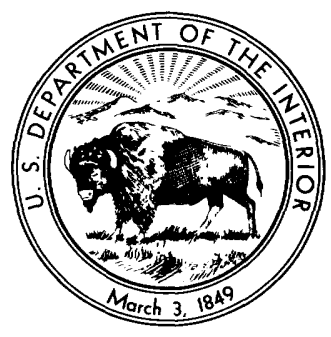




\section{UNITED STATES DEPARTMENT OF THE INTERIOR}

ROGERS C. B. MORTON, Secretary

GEOLOGICAL SURVEY

William T. Pecora, Director

Library of Congress catalog-card No. 70-610218

For sale by the Superintendent of Documents, U.S. Government Printing Office Washington, D.C. 20402 - Price $\$ 1$ (paper cover) 


\section{CONTENTS}

\begin{abstract}
.

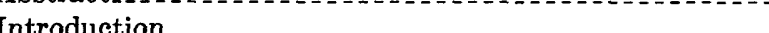

Acknowledgments

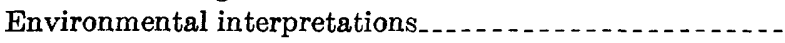

Interpretations based on regional geology . . . . . .

Interpretations based on Foraminifera.......

Interpretations based on macrofossils..........

Comparison of foraminiferal faunas between the stratigraphic units.
\end{abstract}

\begin{tabular}{|c|c|c|}
\hline Page & & Page \\
\hline C1 & Vertical distribution and biostratigraphy & $\mathrm{C7}$ \\
\hline 1 & Problems in the study of Foraminifera of western interior & \\
\hline 1 & United States & 7 \\
\hline 1 & Stratigraphic positions of the samples & 14 \\
\hline 1 & Sample preparation & 15 \\
\hline 4 & Systematic paleontology & 15 \\
\hline 5 & References cited. & 50 \\
\hline 6 & Index & 53 \\
\hline
\end{tabular}

\section{ILLUSTRATIONS}

[Plates 1-7 follow index]

Plate 1. Alabamina, Ammobaculites, Ammobaculoides?, Anomalinoides, Astacolus, Bathysiphon, Bulimina, and ?Buliminella.

2. Caucasina, Cibicides, Dentalina, Dorothia, Eouvigerina, Fissurina, Globigerinelloides, and Glomospira.

3. Frondicularia, Gaudryina, Glomospirella, and Gyroidina.

4. Haplophragmoides, Lagenammina, and Pseudobolivina?.

5. Heterohelix, Lagena, Len'iculina, Marginulina, Oolina, Pseudoclavulina?, Reophax, Saccammina, and Saracenaria.

6. Neobulimina, Silicosigmoilina, Spiroplectammina, and Trochammina.

7. Nodosaria, Stilostomella, Textularia, Trochammina, Verneuilinoides, and incertae sedis.

Figure 1. Graphs showing changes in foraminiferal faunal size and gross composition, bathymetry based on macrofossils, and strandline position during deposition of the Pierre Shale at Red Bird, Wyo....

2. Chart showing ranges and relative abundances of foraminiferal species which have restricted local ranges, are typically represented by numerous specimens, and are morphologically distinctive.......................

3. Chart showing ranges of foraminiferal species in the Pierre Shale at Red Bird, Wyo., and their composite ranges from elsewhere in the Cretaceous interior seaway . .

4. Outline drawings of Spiroplectammina sp. 1 and of a topotype of S. semicomplanata

\section{TABLES}

TABLE 1. Summary of foraminiferal ratios and faunal-sample relationships

2. Sizes and comparisons of macrofossil collections

3. Ranges and relative abundances of foraminiferal species

4. Percentage of samples in each stratigraphic unit in which each species of Foraminifera is found...

5. Stratigraphic positions of the samples. 


\section{.}




\title{
FORAMINIFERA FROM THE PIERRE SHALE (UPPER CRETACEOUS) AT RED BIRD, WYOMING
}

\author{
By James F. MeLLo
}

\begin{abstract}
Foraminifera were recovered from 75 samples taken from the complete section of the Pierre Shale exposed at Red Bird, Wyo. Arenaceous Foraminifera are dominant in most samples, both in number of species and number of specimens, but some samples contained calcareous benthonic and planktonic specimens, and many samples yielded internal molds of presumably calcareous species. Patterns of distribution of identifiable foraminiferal taxa show no convincing relationship with regional depositional history, macrofossil occurrences, or Holocene distributional patterns. Most foraminiferal species are rare and oocur sporadically, and most of the rest are long ranging, either locally or regionally. No biostratigraphic subdivisions are proposed.

Of the 61 identified taxa, 46 are assigned positively or provisionally to previously named species, one species is described as new, and 14 taxa bear informal species nomenclature. The species Haplophragmoides excavata Cushman and Waters is emended to include five morphologic subgroups.
\end{abstract}

\section{INTRODUCTION}

The discovery of a well-exposed complete section of the Pierre Shale at Red Bird, Niobrara County, Wyo., by U.S. Geological Survey geologists and its subsequent intensive investigation (Gill and Cobban, 1966 ; Sohl, 1967) provided a theoretically ideal framework for the study of Foraminifera. Careful stratigraphic work was done, and fine zonation based on mollusks was established. This created an excellent opportunity for relating the Foraminifera from the Pierre Shale to widely recognized fossil zones and regionally important stratigraphic units.

Despite the promise of these initial conditions, the results of this study were less than expected. The Foraminifera are monotonous in general faunal character. Nearly all recovered faunas are arenaceous and not very diverse, and most species are long ranging. All three factors limit the usefulness of these Foraminifera for zonation and environmental interpretation. If the character of foraminiferal faunas at Red Bird reflects the faunal character predominating in the Pierre Shale of other areas, the data and conclusions presented here may be of wider use than presently expected.

\section{ACKNOWLEDGMENTS}

Considerable help received from William A. Cobban, James R. Gill, and Robert E. Burkholder, U.S. Geological Survey, is gratefully acknowledged. Elinor Stromberg, U.S. Geological Survey, made the drawings of Foraminifera. Thanks are also due Cobban and Norman F. Sohl, U.S. Geological Survey, and Dr. John H. Wall, Research Council of Alberta, who reviewed the manuscript.

\section{ENVIRONMENTAL INTERPRETATIONS}

\section{INTERPRETATIONS BASED ON REGIONAL GEOLOGY}

In general lithologic character, the Pierre Shale at Red Bird "*** consists of dark- to light-grayweathering noncalcareous clayey to silty shale that is entirely of marine origin" (Gill and Cobban, 1966, p. A1). During deposition at Red Bird, the nearest strandlines were to the west and northwest. According to Gill and Cobban (1966, p. A37), the strandline was about 185-205 miles west of Red Bird during Gammon time, 135-160 miles to the west during Mitten time, and probably no more than 60 miles away during deposition of the Red Bird Silty Member (see fig. 1). Immediately after deposition of the Red Bird Silty Member, the strandline moved about 110 miles west of Red Bird, during which time the lower third of the lower unnamed member was deposited. While the middle third of the lower unnamed member was being deposited at Red Bird, uplift and erosion took place to the west, accompanied by a probable regression of the strandline nearer to Red Bird. Renewed transgression shifted the strandline to a point 150 miles west of Red Bird during deposition of the upper third of the lower unnamed member, the Kara Bentonitic Member, and the basal part of the upper unnamed member. During deposition of the upper unnamed member, the strandline shifted eastward and southeastward and was as close as 60 miles north of Red Bird during deposition of the upper third of the unit. The strandline was probably never nearer than 40 miles from Red Bird, and it was usually 100 or more miles away. 

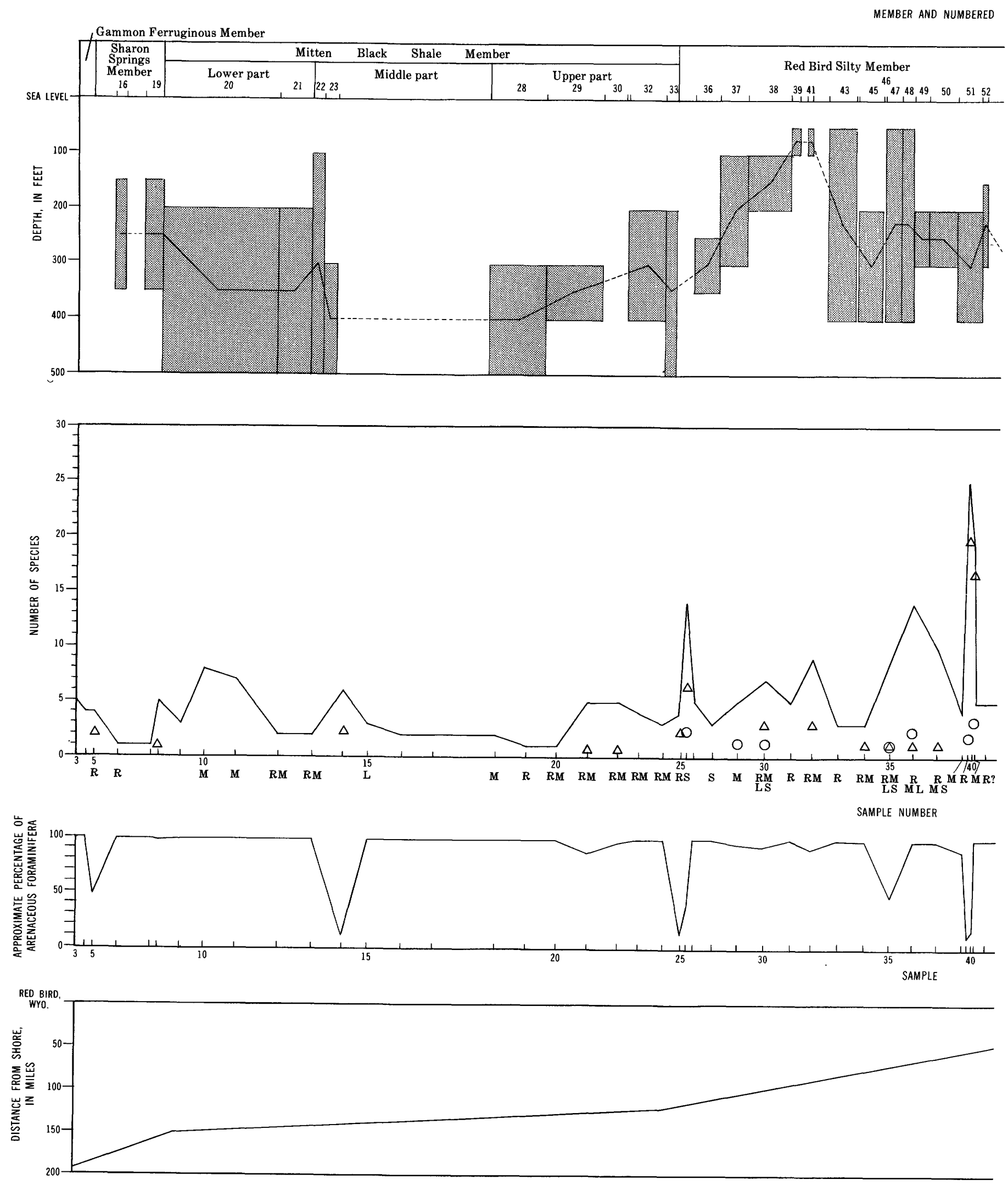

Figdre 1.-Changes in foraminiferal faunal size and gross composition, bathymetry based on 
UNIT OF MEASURED SECTIDN
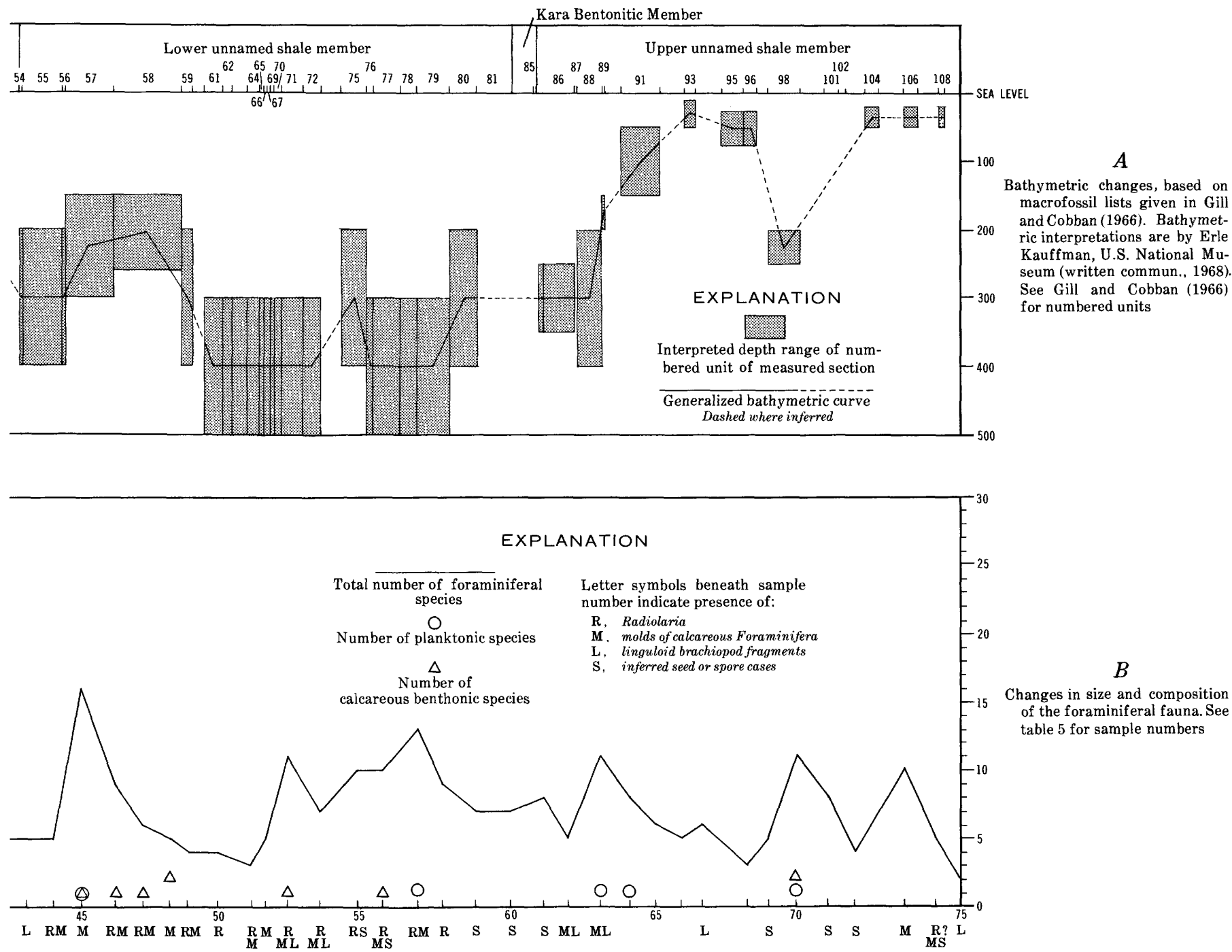

AND FOSSILS

C

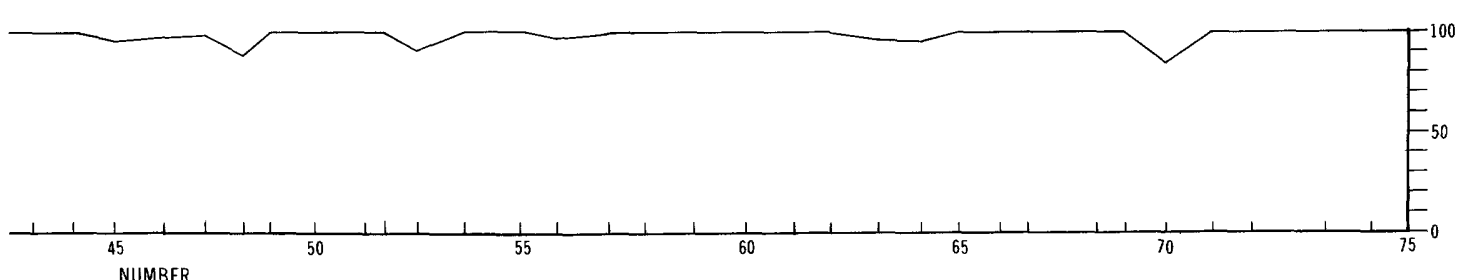

Changes in approximate percentage of arenaceous Foraminifera in the foraminiferal fauna, determined by assuming median absolute values for the relative abundance catagories used in this study

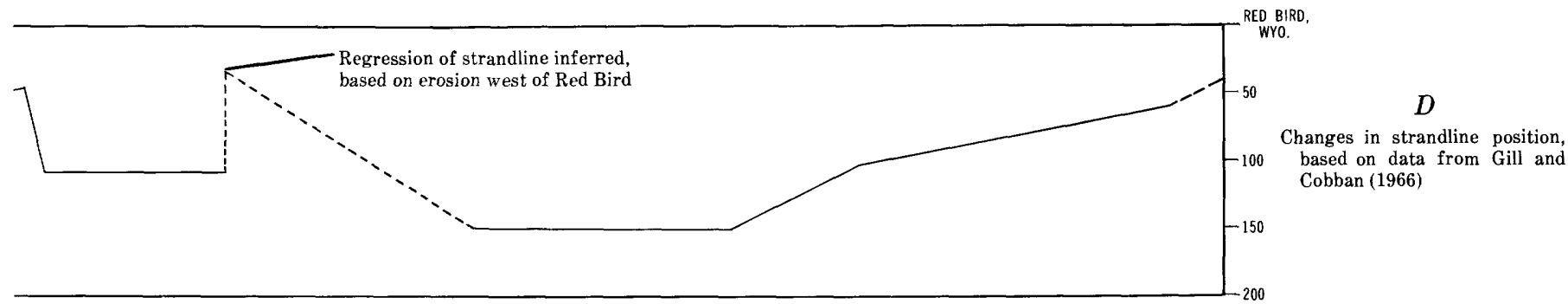

macrofossils, and strandline position during deposition of the Pierre Shale at Red Bird, Wyo. 
Knowledge of the distance of the site of deposition from the shoreline, although helpful, is not sufficient evidence for interpreting the depth of the sea. Gill and Cobban (1966, p. A37-A38) summarized other lines of reasoning, based for the most part on inorganic criteria, which suggest that the Mitten and younger members were deposited at depths less than 200 feet and that the Gammon Ferruginous and Sharon Springs Members were deposited at depths greater than 200 feet.

\section{INTERPRETATIONS BASED ON FORAMINIFERA}

Observation of living Foraminifera in Holocene environments is exceedingly difficult because of their small size. Little is known about the degree of ecologic control exerted by food preferences, temperature, light, turbidity, $\mathrm{pH}, \mathrm{Eh}$, and other factors, and no work has been done on functional morphology. Owing to ignorance of the relationship of the organisms to these basic factors, information on environmental relationships has been almost exclusively descriptive rather than meaningfully interpretive.

Specifically, distribution of Foraminifera has been related to depth more than to any other parameter. Data have been accumulated relating species, genera, and various ratios between taxa and between gross shell structure or living habits to depth in general and to specific Holocene environments in particular. Use of such information on Holocene Foraminifera for the interpretation of Cretaceous paleoenvironments is limited almost exclusively to comparison of planktonicbenthonic and arenaceous-calcareous benthonic ratios, and to generalizations based on characteristics such as faunal diversity. Most fossiliferous samples examined from the Pierre Shale at Red Bird were dominated by

TABLE 1.-Summary of foraminiferal ratios and faunal-sample relationships

\begin{tabular}{|c|c|c|c|c|c|c|c|c|c|}
\hline Lithologic unit & 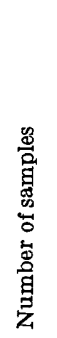 & 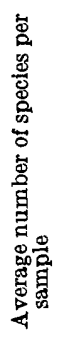 & 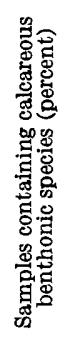 & 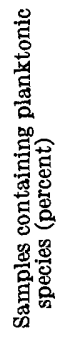 & 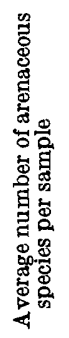 & 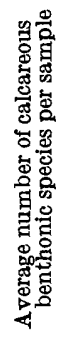 & 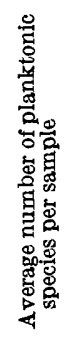 & 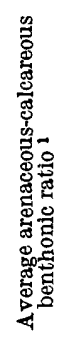 & 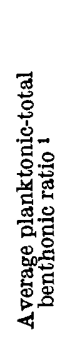 \\
\hline $\begin{array}{l}\text { Upper unnamed shale member- } \\
\text { Lower unnamed shale member- } \\
\text { Red Bird Silty Member. } \\
\text { Mitten Black Shale Member: }\end{array}$ & $\begin{aligned} & 15 \\
- & 18 \\
- & 18\end{aligned}$ & $\begin{array}{l}6.3 \\
7.6 \\
8.2\end{array}$ & $\begin{array}{r}6.7 \\
33.3 \\
61.2\end{array}$ & $\begin{array}{l}20.0 \\
11.1 \\
38.8\end{array}$ & $\begin{array}{l}6.0 \\
7.1 \\
4.9\end{array}$ & $\begin{array}{l}0.1 \\
.4 \\
2.8\end{array}$ & $\begin{array}{r}0.2 \\
.1 \\
.7\end{array}$ & $\begin{array}{r}46.0 \\
18.0 \\
1.8\end{array}$ & $\begin{array}{r}0.03 \\
.01 \\
.09\end{array}$ \\
\hline $\begin{array}{l}\text { Upper part } \\
\text { Middle part. } \\
\text { Lower part } \\
\text { Sharon Springs Member } \\
\text { Gammon Ferruginous Member. }\end{array}$ & $\begin{aligned}- & 7 \\
-\quad & 5 \\
-\quad & 5 \\
-\quad & 3 \\
- & 2\end{aligned}$ & $\begin{array}{l}3.0 \\
3.0 \\
4.6 \\
2.0 \\
4.5\end{array}$ & $\begin{array}{l}28.6 \\
20.0 \\
20.0 \\
33.3 \\
0\end{array}$ & $\begin{array}{c}0 \\
20.0 \\
0 \\
0 \\
0\end{array}$ & $\begin{array}{l}2.7 \\
2.2 \\
4.4 \\
1.3 \\
4.5\end{array}$ & $\begin{array}{l}.3 \\
.4 \\
.2 \\
.7\end{array}$ & $\begin{array}{l}0 \\
0 \\
0 \\
0 \\
0\end{array}$ & $\begin{array}{r}9.3 \\
5.5 \\
22.0 \\
2.0 \\
0\end{array}$ & $\begin{array}{l}0 \\
0 \\
0 \\
0 \\
0\end{array}$ \\
\hline
\end{tabular}

1 Based on number of species, not number of specimens. arenaceous Foraminifera, in terms of both number of specimens and number of species (table 1). Identifiable specimens of calcareous-walled Foraminifera were present in only a few samples.

However, many samples that yielded no intact calcareous-walled specimens did contain partial or complete internal molds of presumably calcareouswalled specimens preserved as pyrite (see fig. $1 B$ ), and most seemed to represent buliminid specimens. Preservation of large-chambered buliminids seems to be preferential, and therefore the composition of the original fauna cannot be known. Because of this uncertainty, the paleoenvironment could not be satisfactorily deduced on the basis of Red Bird foraminiferal evidence. ${ }^{1}$

Table 1 summarizes relationships between foraminiferal faunal elements (excluding internal molds) from the Pierre Shale at Red Bird. The very low representation of planktonic specimens and species and the simple internal structure of the arenaceous species suggest that deposition was not at bathyal or abyssal depths. The fine grain size of the sediment suggests deposition in a relatively low energy setting, and regional geological evidence indicates deposition of most of, if not all, the Pierre at a distance at least 60 miles from shore. Thus, available evidence suggests that deposition occurred at water depths similar to those over Holocene continental shelves.

Although the Red Bird faunas cannot confidently be considered among them, largely or wholly arenaceous faunas were reported a number of times from deposits of the Cretaceous interior seaway. These faunas were reported by Tappan (1962) from the Cretaceous of Alaska; by Eicher (1960, 1965, 1966, 1967) from the Cretaceous of the western interior of the United States; and by Stelck, Wall, Bahan, and Martin (1956), Wall (1967b), Stelck and Wall (1954, 1955), Wall (1960), Wall and Germundson (1963), Mellon and Wall (1956), and Stelck, Wall, and Wetter (1958) from the Cretaceous of Canada. Three general environmental interpretations based on the arenaceous character of these faunas were made: (1) the water was of less than normal salinity and shallow, (2) the water was cold, or (3) the faunas lived at considerable depth. In some of the cited papers, especially Tappan (1962), further discussion of possible paleoenvironmental controls is offered, but it seems fair to say that all interpretations are based directly on analogy with Holocene conditions, and little atten-

1 Use of terms such as "Red Bird foraminiferal fauna" or "Red Bird Foraminifera" is not meant to refer exclusively to the Red Bird Silty Member. Unless otherwise specified, their use will have wider meaning depending on the context. 
tion is paid to lines of evidence, other than the foraminiferal, that might bear on the interpretation of environment. In my opinion, however, sufficient information is now available on Holocene foraminiferal distribution to throw serious doubt on each of these general interpretations.

Does Holocene environmental evidence support a shallow-water reduced-salinity environment for these largely arenaceous Cretaceous faunas? Phleger (1960, p. 149, 150) listed the species found in some lagoons, estuaries, and marshes, most of which have salinities below normal. Calcareous species were present in all lagoons and were more numerous than arenaceous species in four of the five lagoons. Calcareous species were also present in two of three estuary assemblages and in three of four of Phleger's marsh assemblages, although fewer in number than arenaceous species in both environments. Holocene assemblages dominated by arenaceous Foraminifera in environments of lowered salinity are areally restricted. In contrast, such Cretaceous assemblages are known over wide areas for the Thermopolis Shale (Eicher, 1960) and for the Graneros Shale (Eicher, 1965). If lowered salinity is used as an explanation for such assemblages, based on Holocene distributions, it seems logical to require that the total environment containing such assemblages be inferred for pertinent areas of the Cretaceous seaway. A very large and persistent marsh or estuary would serve as the environment of deposition, but when all geologic and paleontologic evidence is considered, both marsh and estuary seem very unlikely.

I cannot positively state that lowered salinity, coupled with a lack of tolerant calcareous species like those that evolved in the Tertiary and inhabit Holocene lagoons, was not the main environmental factor governing faunal composition. The tie, however, between the Cretaceous assemblages and the lowered salinity environments that harbor even grossly similar assemblages today does seem tenuous, and the adoption of a single environmental factor characteristic of those environments to explain the relationship is open to very serious doubt.

Several authors cited cold-water temperature as a possible environmental control promoting largely or exclusively arenaceous foraminiferal assemblages. Leslie (1965), in a study on the ecology of Holocene Foraminifera from Hudson Bay, showed that diverse calcareous near-shore faunas live most of the year in water temperatures as low (about $0^{\circ} \mathrm{C}$ ) as those in which dominantly arenaceous assemblages live in deeper water. Temperature, in conjunction with other environmental factors, undoubtedly has an effect on the foraminiferal population, but the presence of calcareous species in extremely cold water makes untenable the interpretation of the Cretaceous arenaceous foraminiferal assemblages as cold-water assemblages because of the absence of calcareous species.

Finally, several authors inferred a deep-water origin for arenaceous foraminiferal assemblages. Such inferences are on firmer ground at the outset than are those used in the other interpretations because they rely on the observed fact that assemblages dominated by arenaceous specimens do occur in Holocene deep-water environments, without attempting to relate this occurrence to any one environmental parameter. In open ocean areas, the largely arenaceous continental slope and bathyal assemblages are usually associated with large numbers of planktonic specimens. In Hudson Bay (Leslie, 1965), planktonic specimens are scarce and localized, and faunas that consist of 80-90 percent arenaceous specimens are in water 50-200 meters deep. According to Bandy and Arnal (1960, p. 1925), deepwater arenaceous species in Holocene oceans tend to have complicated interior structures. Species with such structures are absent throughout the deposits of the Cretaceous seaway.

In summary, analogies with the Holocene based on very few or very general criteria are not reliable in the interpretation of the living environments of Cretaceous foraminiferal faunas composed largely or completely of arenaceous specimens.

\section{INTERPRETATIONS BASED ON MACROFOSSILS}

Macrofossil collections at Red Bird were made almost exclusively from concretion horizons. Comparison of foraminiferal faunas with these collections is limited in several ways. Fossiliferous concretions are sandwiched between shale layers, which are immediately juxtaposed where concretions are absent, so that the exact time interval represented by the concretions is apparently not represented in the shale. The postdepositional geochemical history of these two distinct lithologies is almost certainly different; therefore, the extent to which original faunas are represented in these lithologies is probably different. Post-mortem transport, which obviously took place before the preservation of macrofossils in some concretions, cannot be documented for foraminiferal assemblages, and the distances of such transport cannot be determined. Despite differences in preservational history, attempts were made to discover parallels in macrofossil and microfossil assemblages which might throw light on paleoenvironments. The number of macrofossil species of all types reported by Gill and Cobban (1966, 
p. A50-A62) from each numbered collecting locality was plotted against the number of foraminiferal species from the same stratigraphic interval. No parallel trends between number of macrofossil species and number of foraminiferal species from samples stratigraphically near the macrofossil collecting sites were observed. There is an increase in the average number of species of macrofossils (table 2) per collecting horizon from the bottom of the Pierre Shale to the top, the highest average being in the upper unnamed shale member. The Foraminifera have no apparent trend but show a distinct separation between the upper and lower parts of the Pierre in terms of average number of species per sample in a unit (table 1 and fig. $1 B$ ).

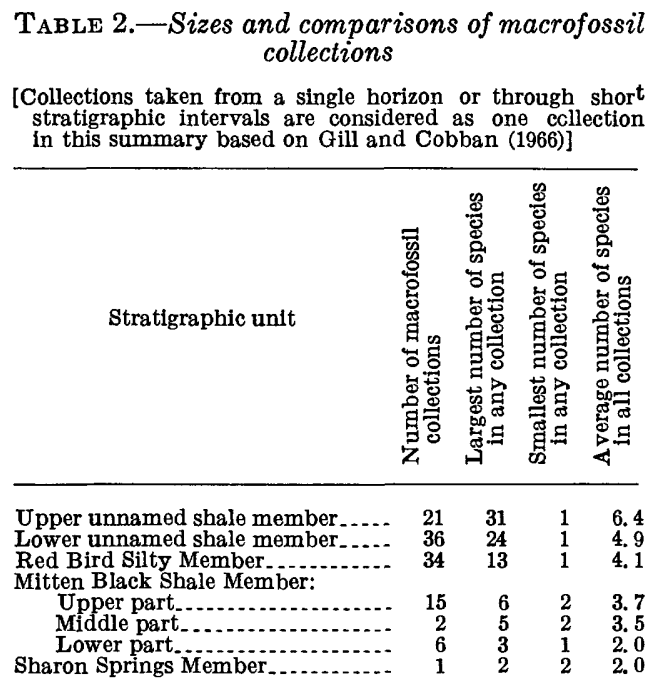

The stratigraphic and assemblage relationships of the macrofossils were considered by Dr. Erle Kauffman, U.S. National Museum, and his conclusions are summarized below. Functional morphology and analogy with the distribution of genetically related forms in the Holocene were used in this analysis. He concluded (written commun., 1967) that the Pierre Shale at Red Bird was probably deposited in normally saline waters at depths similar to those over the modern continental shelves. A diagrammatic representation of probable water depths is shown in figure $1 A$. The Gammon Ferruginous Member yielded no macrofossils. The Sharon Springs Member is interpreted to have been deposited at middle to outer shelf depths, probably in cold waters or on bottoms that were toxic or oxygen deficient, or both. Shallowing during deposition of the upper part of the Mitten Black Shale Member, culminating in shallow-water deposition for the Red Bird Silty Member, was accompanied by warming of the water or transition to more hospitable bottom conditions or both. Moderate deepening is indicated during deposition of the lower unnamed member, and shoaling is indicated during deposition of the upper part of the upper unnamed member, culminating in the shallow-water deposition of the Fox Hills Sandstone.

There is no discernible reflection of these inferred depth changes in the foraminiferal faunas. The upper part of the Mitten Member, the lower part of the lower unnamed member, and the middle or upper part of the upper unnamed member should have been deposited at similar depths, but there is no recurrence of foraminiferal species assemblages for these intervals.

Similarly, the Red Bird Silty Member and the upper part of the upper unnamed member should have been deposited at the same depths, but this is not reflected in the foraminiferal faunas. Parts $B$ and $C$ of figure 1 show that total number of species per sample, the number of arenaceous, calcareous benthonic, and planktonic species per sample, and the approximate percentage of arenaceous, calcareous benthonic, and planktonic specimens per sample. Most of these relationships are averaged for the lithologic units in table 1. Again, there is no convincing correlation between the relationships and the depth pattern inferred from the macrofossils.

Figure $1 B$ shows that the number of species per sample increases at the base of the Red Bird Silty Member. With some reversions to fewer species, this faunal diversity remains generally high to the upper part of the upper unnamed member. Also, the number of calcareous specimens is very low throughout the section except for several samples in the Red Bird Silty Member and single samples in the Gammon Member and in the middle and upper parts of the Mitten Member. The relationship, if any, between these patterns and regional geologic, lithologic, or macrofossil environmental evidence is not apparent.

\section{COMPARISON OF FORAMINIFERAL FAUNAS BETWEEN THE STRATIGRAPHIC UNITS}

Foraminiferal faunas recovered from the upper part of the Mitten Member and units below it contained only one-half to two-thirds as many species in an average sample as were found in the Red Bird Silty Member and younger units. This increase was largely due to an increase of arenaceous species. Only in the Red Bird Silty Member did the average number of calcareous benthonic species in a sample exceed 0.7 and the average number of planktonic species in a sample exceed 0.4. Planktonic species occurred in each of the unnamed members and in the Red Bird Silty 
Member, but below the Red Bird Silty Member they were found only in the middle part of the Mitten Member. The Red Bird Silty Member yielded a greater percentage of samples that contained calcareous benthonic and planktonic species than did any other unit; this is consistent with the greater frequency of occurrence of both these kinds of Foraminifera in an average sample. In summary, the percentages in table 1 show that the upper unnamed member, lower unnamed member, and Red Bird Silty Member are more like each other in most respects than they are like any one of the underlying Pierre units. Likewise, the units from the upper part of the Mitten Member to the Gammon Member seem to resemble each other rather closely in all the averaged parameters.

\section{VERTICAL DISTRIBUTION AND BIOSTRATIGRAPHY}

The distribution and estimated abundances of all species and samples studied are shown in table 3. Table 4 shows the range of each species and the percentage of samples from each unit in which each species occurs. Of the 61 species depicted, 33 occurred in one formation only. Twenty of these 33 occurred in only one sample each, nine occurred in two samples each, and none of the remaining species restricted to a single unit occurred in more than 22 percent of the samples from that unit. Only indeterminate specimens of Haplophragmoides occurred in all units, and only Bathysiphon brosgei and Saccammina complanata range from the Gammon Ferruginous Member to the upper unnamed shale member. Of the remaining 25 species, three stand out as occurring in all units within their ranges and in a high proportion of the samples in these units: Glomospirella inconstans, Dorothia smokyensis, and Haplophragmoides excavata. The ranges of these species and of nine others that have relatively restricted ranges and that occur frequently within their ranges are shown in figure 2. Because of their frequency of occurrence within restricted ranges, these 12 species are theoretically best suited for use in biostratigraphically subdividing the Pierre Shale.

Included among these 12 species are Vermeuilinoides cf. V. perplexus, Trochammina cf. T. wetteri, T. diagonis, Lagenammina diffugiformis, Haplophragmoides excavata s. l., and Textularia sp. 1 which are commonly not well preserved in the samples from the Red Bird area. If this poor preservation is characteristic of these species, their recognition elsewhere will be seriously impaired.

The scarcity of easily identifiable species that are restricted in range and that occur in most samples within their ranges makes it unwise to formally subdivide the Pierre Shale into foraminiferal zones at this time. Figure 3 compares the ranges of the species occurring at Red Bird with their ranges elsewhere in the western interior. The ranges of most species at Red Bird are less than their cumulative ranges in the western interior. More work on Pierre Shale and ageequivalent foraminiferal faunas is needed before much confidence can be placed on foraminiferal biostratigraphic subdivisions applicable within either the western interior region of the United States or within the entire interior seaway.

A broad-scale biostratigraphic study of Cretaceous Foraminifera in Canada was presented by Wall (1967a). Of the zones recognized by him, only that of Trochammina ribstonensis seems to be represented at Red Bird. Two of the five species that Wall listed as conspicuous in this zone are found together at Red Bird: Trochammina ribstonensis and Dorothia smokyensis. These two species are especially common in the lower part of the Mitten Member at Red Bird, and there is a possible occurrence in the upper part of the Mitten.

Dorothia smokyensis is more commonly represented and very abundant in the upper half of its local range, which extends to the upper part of the upper unnamed shale member. Trochammina ribstonensis was also reported from rocks of late Campanian and early Maestrichtian ages in the interior seaway, and its presence suggests that environmental controls, possibly the fairly shallow probably somewhat turbid environment suggested by Wall (1967a, p. 190), are responsible for the restricted range of this species in some areas. The $T$. ribstonensis fauna of the Rocky Mountain foothills of Canada occurs in rocks of late Santonian and early Campanian age, slightly older than the strata containing $T$. ribstonensis and $D$. smokyensis at Red Bird.

\section{PROBLEMS IN THE STUDY OF FORAMINIFERA OF WESTERN INTERIOR UNITED STATES}

Nearly all specimens of Haplophragmoides, the most abundantly represented genus in the Red Bird samples, Trochammina, and species of several other genera were distorted during compaction of the enclosing sediment. Distortion of form is common to many agglutinated Cretaceous species from the western interior and is probably due to an original flexibility of the wall. Study of distorted specimens is difficult because of the varied shapes secondarily imposed on specimens of the same species and because of the concomitant loss of detail, especially apertural detail. 


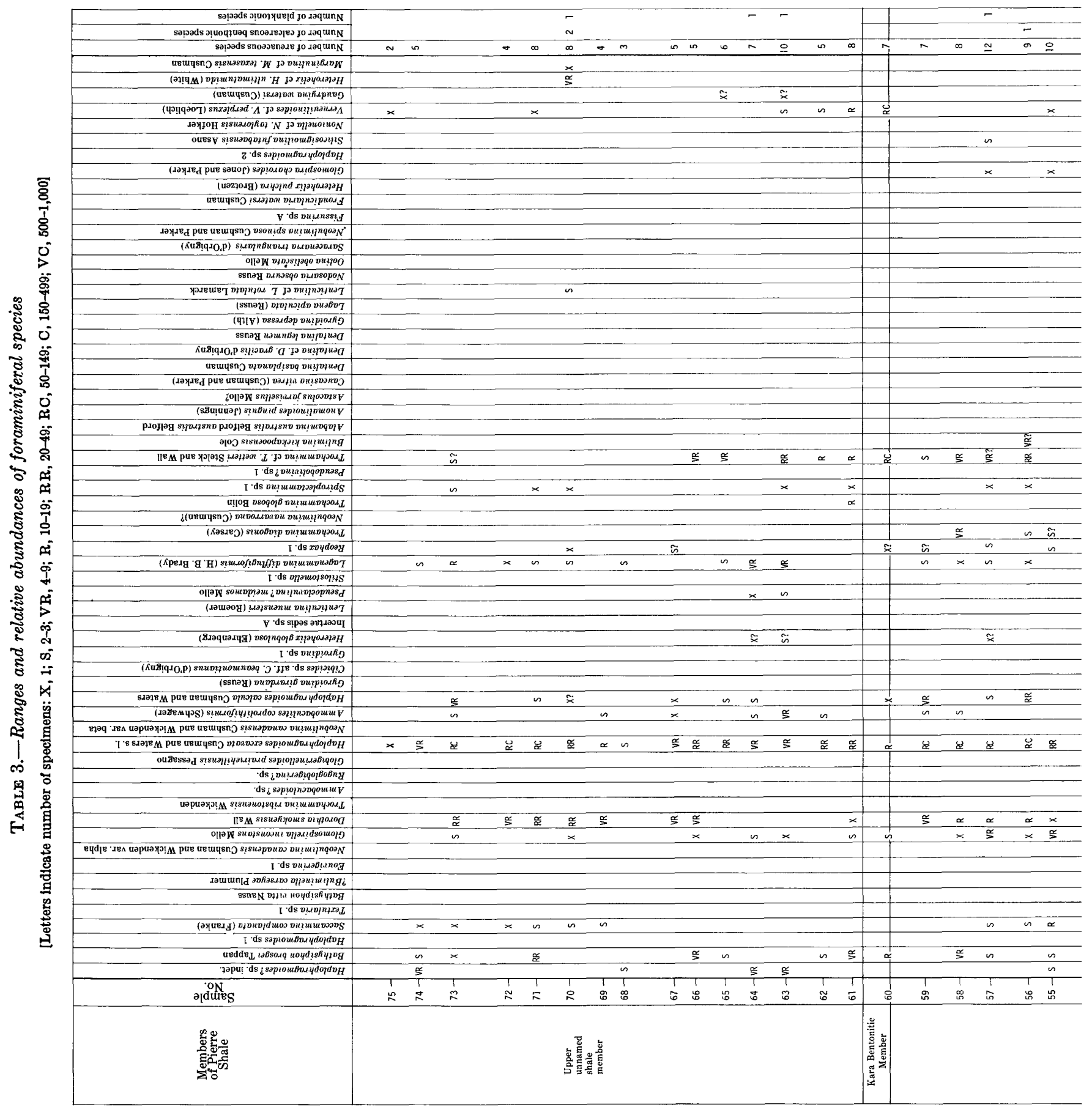




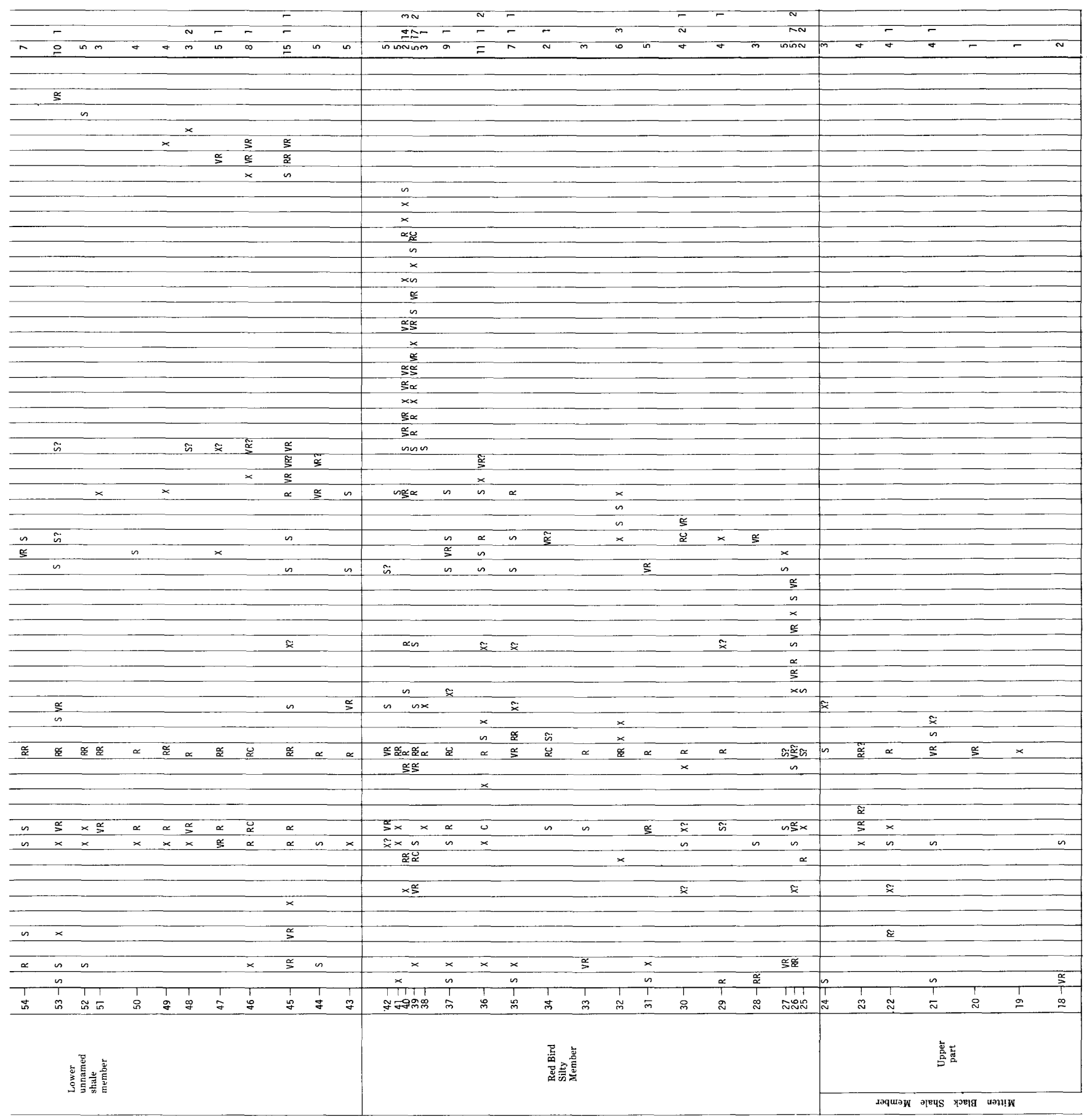




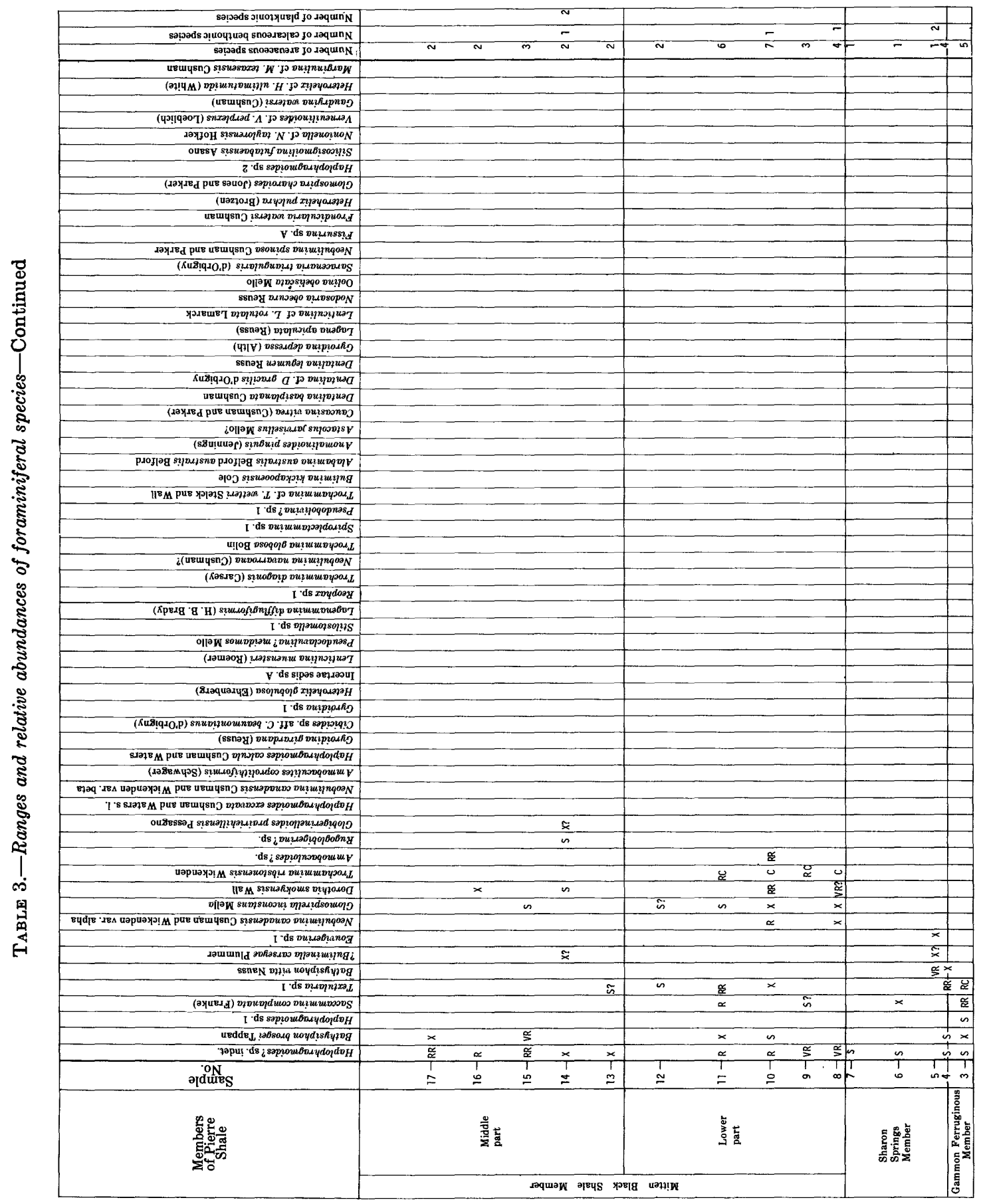



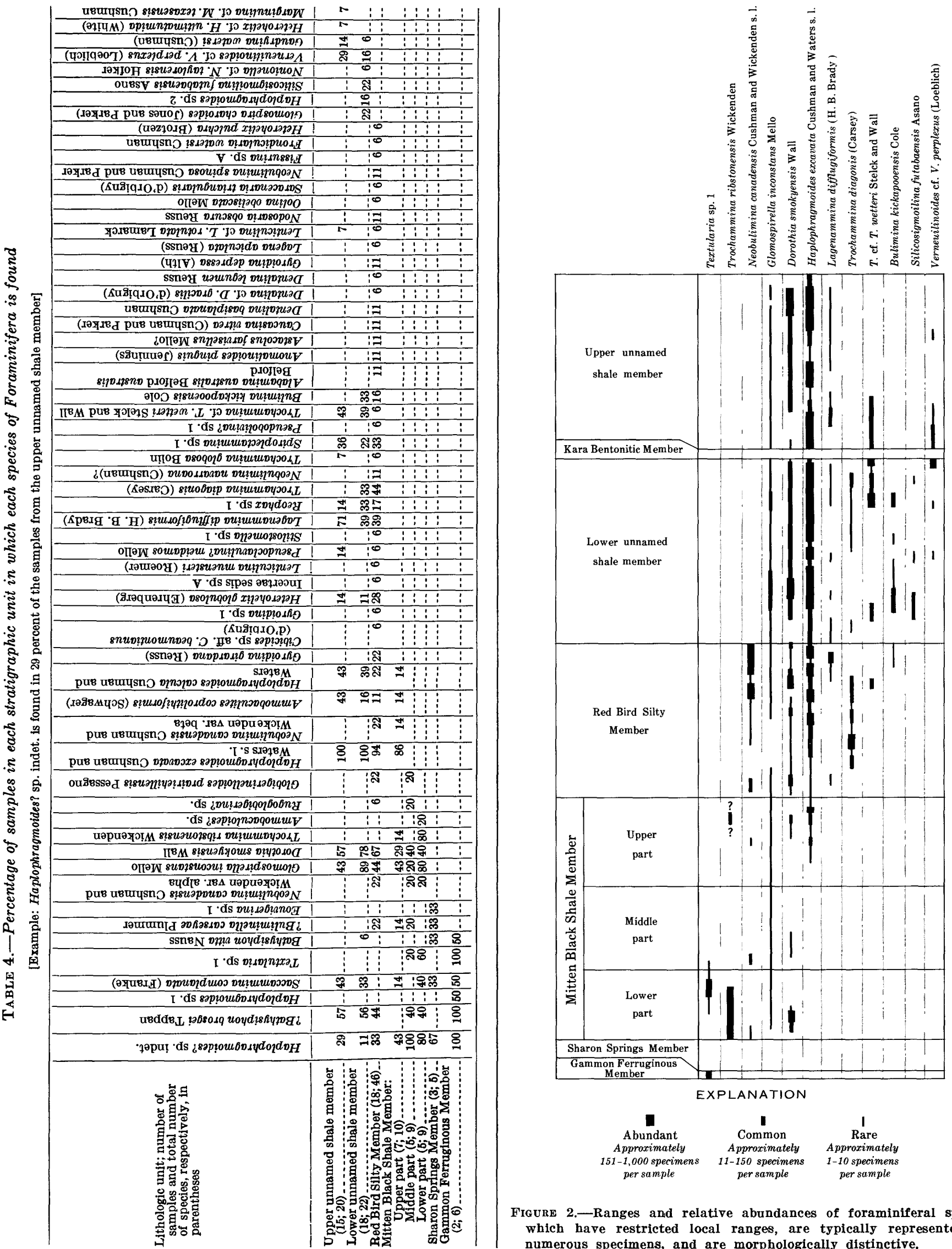

Figure 2.-Ranges and relative abundances of foraminiferal species which have restricted local ranges, are typically represented by numerous specimens, and are morphologically distinctive. 

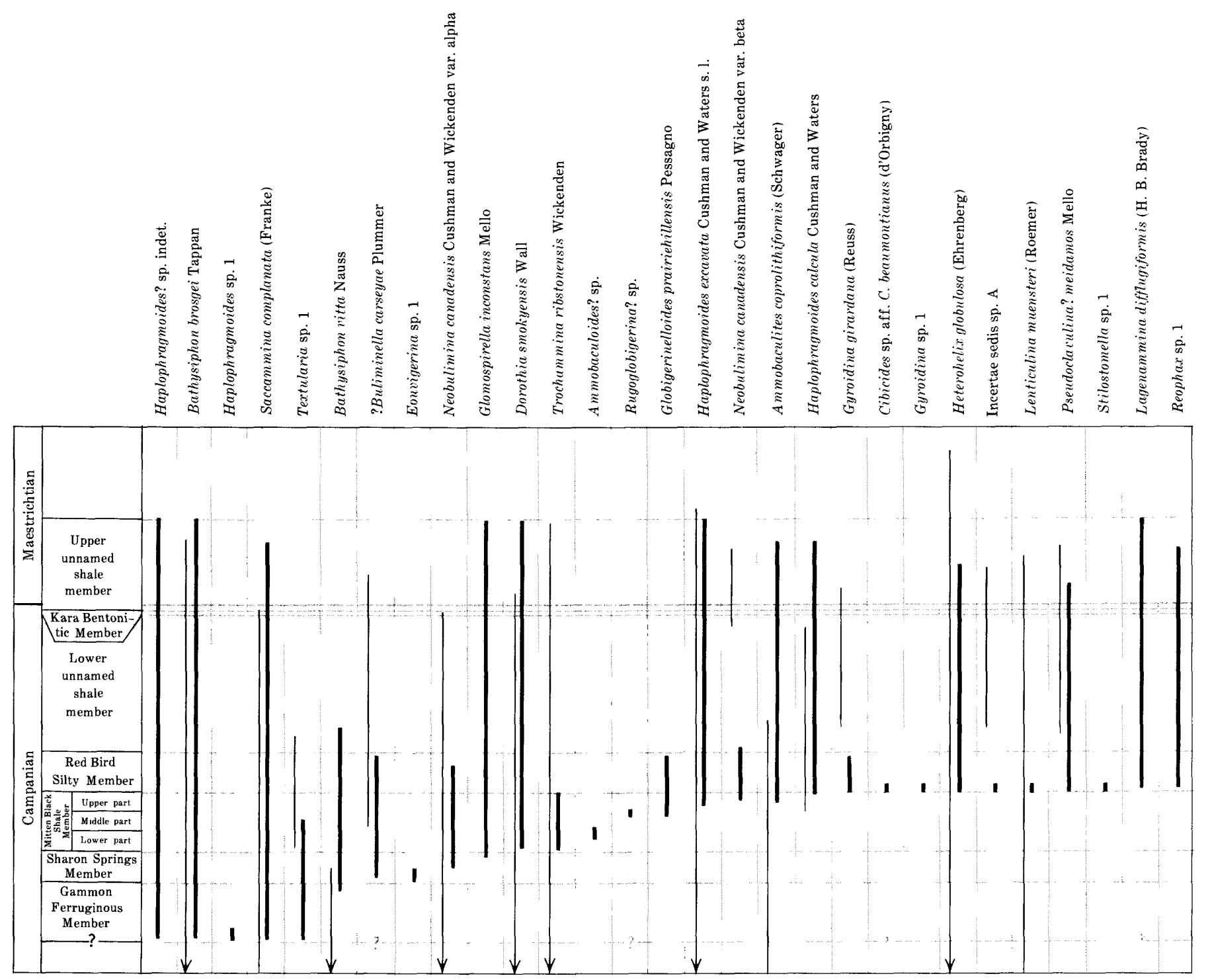

Figure 3.-Ranges of foraminiferal species in the Pierre Shale at Red Bird, Wyo., and their composite ranges from elsewhere in the Cretaceous interior seaway. 


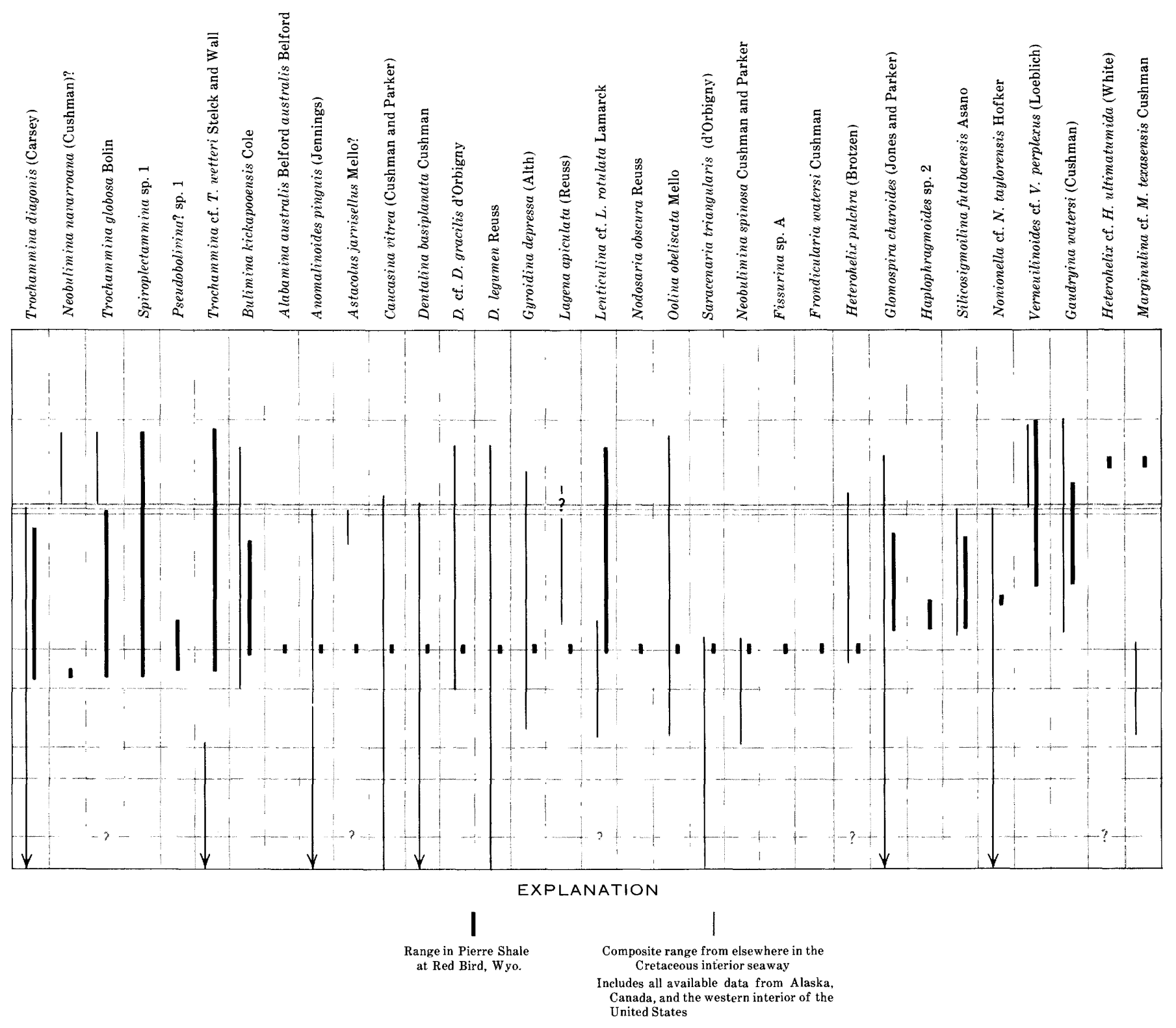


In practice, I found that almost total dependence for discrimination between specimens of different species must often be placed on features that are of low or doubtful diagnostic significance.

The characters most generally used in the study of the agglutinated Red Bird specimens were:

1. Number of chambers or range of numbers of chambers in the final whorl and any other visible whorls of coiled specimens. This number is usually fairly easily determined, but in itself is of little practical use unless the number is unusually large or small.

2. Chamber size and shape. This character is difficult to determine in many specimens that have been badly distorted.

3. Size of agglutinated particles and smoothness of the test wall. These features are little affected by distortion, but suites of otherwise similar specimens have shown large variations in these characters so that they, too, must be considered of limited value.

4. Degree of involution and height of spire in coiled specimens. These features are difficult to assess in many distorted specimens, though they are generally discernible and useful.

5. Color of the wall and specimen size. Both these characters have been found to vary, as would be expected, and are of limited value.

The lack of precision inherent in the above characters, even when it is possible to use some or all collectively, makes identification of many of the agglutinated Red Bird specimens more than normally subjective.

During this study generic determinations were made for all specimens as the first step in taxon identification. Then a search was made among the specimens assigned to each genus, and, using the criteria discussed above, groups of the best preserved specimens having the same characters were set aside for reference purposes. Comparison was then made between each occurrence of that genus in the samples and the groups of reference specimens which were set aside. This process resulted in: (1) the separation of other apparently distinct groups, representatives of which were chosen and set aside for reference purposes, and (2) the combination of previously separated groups where specimens intermediate in character were found. Then all specimens assigned to a particular group were critically compared with each other, doubtful specimens were removed from the group, and descriptions were written for each of the groups (now considered as species). Comparisons were made with the descriptions, figures, and available type specimens of previously described Cretaceous species from the western interior and Gulf Coastal Plain. Typological methodology prevailed in the erection of most western interior and Gulf Coastal Plain foraminiferal species. As a result, sometimes several names were applicable to various distortions of single arenaceous species, and usually no data are given on ranges of morphologic variation. In this study, all available type and comparative specimens of similar species were examined, and variations in the Red Bird specimens are described.

\section{STRATIGRAPHIC POSITIONS OF THE SAMPLES}

Spot samples were taken in the field at approximately 10-foot stratigraphic intervals throughout most of the section, except where exposures were too poor to permit collection of relatively fresh shale, and throughout the Gammon and Sharon Springs Members, where collections were made at 5 -foot intervals. Samples were collected along traverses A and B of Gill and Cobban (1966, p. A5 and pl. 1); the relation to these traverses and to the detailed section description by Gill and Cobban (1966, p. A49-A62) is shown in table 5 .

TABLE 5.-Strategic positions of the samples

[Traverse and unit numbers from Gill and Cobban (1966)]

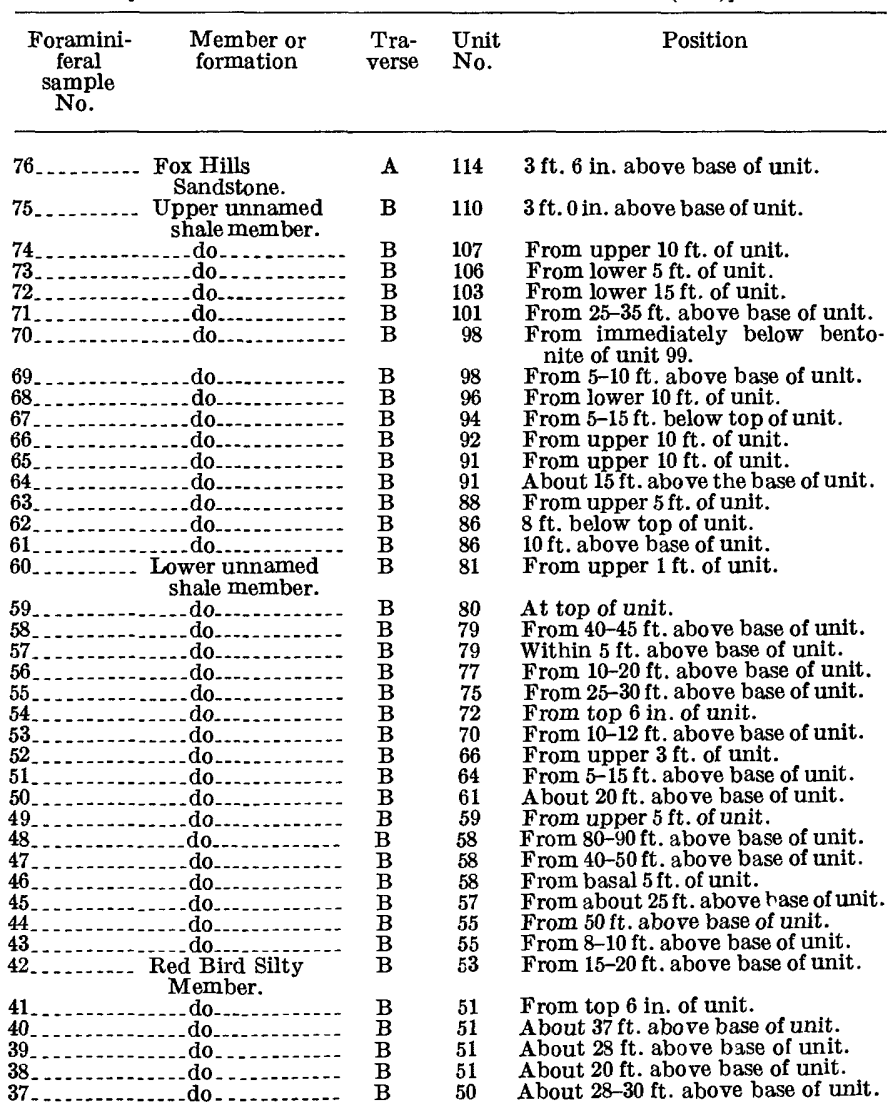


TABLE 5.-Strategic positions of the samples-Continued

\begin{tabular}{|c|c|c|c|c|}
\hline $\begin{array}{l}\text { Foramini- } \\
\text { feral } \\
\text { sample } \\
\text { No. }\end{array}$ & $\begin{array}{l}\text { Member or } \\
\text { formation }\end{array}$ & $\begin{array}{l}\text { Tra- } \\
\text { verse }\end{array}$ & $\begin{array}{l}\text { Unit } \\
\text { No. }\end{array}$ & Position \\
\hline & Red Bird Silty & B & 49 & About 8-10 ft. above base of unit. \\
\hline 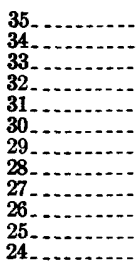 & $\begin{array}{c}\text { do do } \\
\text { do } \\
\text { do } \\
\text { do }\end{array}$ & $\begin{array}{l}\text { B } \\
\text { B } \\
\text { B } \\
\text { B } \\
\text { B } \\
\text { B } \\
\text { B } \\
\text { B } \\
\text { B } \\
\text { B } \\
\text { B }\end{array}$ & $\begin{array}{l}47 \\
45 \\
43 \\
42 \\
39 \\
38 \\
37 \\
36 \\
36 \\
35 \\
34 \\
33\end{array}$ & $\begin{array}{l}\text { About } 20 \mathrm{ft} \text {. above base of unit. } \\
\text { About } 26 \mathrm{ft} . \text { above base of unit. } \\
\text { About } 29 \mathrm{ft} \text {. above base of unit. } \\
\text { About } 13 \mathrm{ft} \text {. above base of unit. } \\
\text { From } 10-15 \mathrm{ft} \text {. above base of unit. } \\
\text { From } 40-50 \mathrm{ft} \text {. above base of unit. } \\
\text { From } 40-48 \mathrm{ft} \text {. above base of unit. } \\
\text { From top } 6 \text { in. of unit. } \\
\text { About } 10 \mathrm{ft} \text {. above base of unit. } \\
\text { From upper } 5 \mathrm{ft} \text {. of unit. } \\
\text { From upper } 2 \mathrm{ft} \text {. of unit. } \\
\text { From } 5-10 \mathrm{ft} \text {. above base of unit. }\end{array}$ \\
\hline & $\begin{array}{l}\text { Dndo veduer. } \\
\text { do do }\end{array}$ & $\begin{array}{l}\text { B } \\
\text { B } \\
\text { B }\end{array}$ & $\begin{array}{l}32 \\
30 \\
29\end{array}$ & $\begin{array}{l}\text { About } 30 \mathrm{ft} \text {. above base of unit. } \\
\text { From upper } 5 \mathrm{ft} \text {. of unit. } \\
\text { From about } 85 \mathrm{ft} \text {. above base of }\end{array}$ \\
\hline & ... do & B & 29 & $\begin{array}{l}\text { unit. } \\
\text { From about } 30 \mathrm{ft} \text {. above base of }\end{array}$ \\
\hline $\begin{array}{l}19 \ldots \\
18-\ldots \\
17-\ldots \\
16-\ldots \\
14-\ldots \\
13-\ldots \\
11-\ldots \\
10 \ldots \\
9\end{array}$ & $\begin{array}{l}\text { do } \\
\text { do } \\
\text { do } \\
\text { do }\end{array}$ & $\begin{array}{l}\mathbf{B} \\
\mathbf{B} \\
\mathbf{A} \\
\mathbf{A} \\
\mathbf{A} \\
\mathbf{A} \\
\mathbf{A} \\
\mathbf{A} \\
\mathbf{A} \\
\mathbf{A} \\
\mathbf{B} \\
\mathbf{B} \\
\mathbf{B}\end{array}$ & $\begin{array}{l}28 \\
28 \\
26 \\
26 \\
25 \\
24 \\
22 \\
21 \\
20 \\
20 \\
20 \\
20 \\
19\end{array}$ & $\begin{array}{l}\text { unit. } \\
\text { About } 75 \mathrm{ft} \text {. above base of unit. } \\
\text { About } 20 \mathrm{ft} \text {. above base of unit. } \\
\text { From } 90-100 \mathrm{ft} \text {. above base of unit. } \\
\text { From } 35-40 \mathrm{ft} \text {. above base of unit. } \\
\text { About } 40 \mathrm{ft} \text {. above base of unit. } \\
\text { About } 20 \mathrm{ft} \text {. above base of unit. } \\
\text { From } 11 \mathrm{ft} \text {. above base of unit. } \\
\text { From } 10-15 \mathrm{ft} \text {. above base of unit. } \\
\text { From } 140-145 \mathrm{ft} \text {. above base of unit. } \\
\text { From } 85-90 \mathrm{ft} \text {. above base of unit. } \\
\text { From } 40-45 \mathrm{ft} \text {. above base of unit. } \\
\text { From } 5 \mathrm{ft} \text {. above base of unit. } \\
\text { From } 20-30 \mathrm{ft} \text {. above base of unit. }\end{array}$ \\
\hline & $\begin{array}{l}\text { Member. } \\
\text { Gammon Ferru- }\end{array}$ & $\begin{array}{l}\text { B } \\
\text { B } \\
\text { B }\end{array}$ & $\begin{array}{r}16 \\
13 \\
8\end{array}$ & $\begin{array}{l}\text { From } 12-15 \mathrm{ft} \text {. above base of unit. } \\
\text { From basal } 6 \text { in. } \\
\text { From upper } 6 \text { in. }\end{array}$ \\
\hline & Niobrara & $\underset{\mathbf{B}}{\mathbf{B}}$ & $\begin{array}{l}8 \\
5\end{array}$ & $\begin{array}{l}\text { From basal } 6 \text { in. } \\
\text { From upper } 6 \text { in. }\end{array}$ \\
\hline & -.do & B & 5 & From basal 6 in. \\
\hline
\end{tabular}

Preliminary examination of samples showed that the foraminiferal faunas were small in number of specimens and low in variety of species, the same species recurring through many feet of section. Consequently, samples were selected for examination at approximately 50 -foot intervals, intervening samples being examined whenever changes in the fauna seemed to warrant it. Seventy-three samples from the Pierre Shale, one from the lower part of the Fox Hills Sandstone, and two from the Niobrara Formation were examined.

Remeasurement of the section at Red Bird, which was carried out by Gill and Cobban after the collection of samples for Foraminifera, resulted in modifications in many unit thicknesses and in the number of units recognized. These modifications were included in the stratigraphic parts of the paper by Gill and Cobban (1966). Because of these changes, many of the samples could not be related to the precise levels from which they were collected. In such cases, the positions of the samples are indicated by reference to unit numbers and parts of the units from which they came.

\section{SAMPLE PREPARATION}

One hundred grams of each sample was boiled in a solution of washing soda and water until satisfactory breakdown was achieved and then washed through a 200-mesh sieve. For many samples, breakdown was incomplete. As a result, the weights of the washed residues do not reflect original amounts of sand-size grains, and these values are not included here. After they were dried, most samples were sieved on 60-, 100-, 150-, and 200-mesh sieves. Approximately equal volumes of sediment were examined from all sieves. Estimates were made of the total number of specimens of each species in each sample, and each estimate was further generalized into one of the following categories:

$\begin{array}{ll}\text { Exclusive } & \text { Specimens and symbol } \\ \text { Scarce }-1 \mathrm{X} \text { - } & \mathbf{1}\end{array}$

\section{SYSTEMATIC PALEONTOLOGY}

Genus alabamma Toulmin, 1941

Alabamina australis Belford australis Belford

Plate 1, figures 1-3

Alabamina australis Belford australis Belford, 1960, Australia Bur. Mineral Resources, Geology and Geophysics Bull. 57, p. 84 , pl. 23 , figs. $13-20$, text fig. 4 , figs. $1-4$ on text fig. 5.

? Eponides sp., North and Caldwell, 1964, Saskatchewan Research Council, Geology Div. Rept. 5, p. 24, pl. 4, figs. 7a-c.

Description.-Test low trochospiral, partially evolute on spiral side, completely involute on umbilical side, with a very shallow and small umbilicus, spiral side slightly convex to slightly concave, umbilical side moderately convex, equatorial periphery smooth or slightly indented at suture lines, axial periphery rather broadly rounded and lacks an imperforate band. Chambers somewhat inflated, closely appressed, five or six, generally six, in the final whorl, increasing fairly regularly and moderately in size as added; in spiral side view, chambers obliquely arranged with respect to the axis of coiling, degree of obliquity often variable from one chamber to the next, resulting in wedge-shaped to trapezium-shaped chambers; in umbilical side view, chambers shaped like abruptly tapering wedges. Sutures on spiral side slightly to markedly oblique, slightly convex forward, slightly or not at all depressed, becoming slightly limbate toward the axis of coiling; sutures on umbilical side radial or slightly oblique, straight, slightly depressed; spiral suture not smooth, the sum of each chamber's 
straight or slightly curved increment. Wall has unclear microstructure, probably granular, rather thin, white, somewhat translucent, smoothly finished, unornamented, polished, very finely perforate. Aperture an interiomarginal opening bordered above by a slight thickening of the septal face and extends on some specimens from the umbilicus nearly to the periphery; peripheral part slightly arched and abuts against the peripheral side of a slightly to moderately pronounced indentation of the septal face; the part of the aperture extending from the arched subperipheral part nearly to the umbilicus is a low slit which is closed in some specimens; the umbilical part of the aperture is represented by a short wedge-shaped slit which widens toward the umbilical tip of the chamber and which is not closed on the final chamber.

Dimensions.-Specimens of average size range from $0.2-0.35 \mathrm{~mm}$ in maximum diameter.

Remarks.-Only a few of the Red Bird specimens preserve the apertural area, so it is impossible to document better the apertural features noted above. In order to clarify the nature of the surficial indentation of the peripheral margin of the apertural face, the umbilical walls of several chambers were dissolved away. Internally there is a downward-plunging structure shaped like a funnel compressed in the plane of coiling and extending along the top of the underlving chamber to about midway between the septae. This structure lies to the peripheral side of the end of the aperture. The indented surface of the apertural face to which the large end of the structure is attached is closed off a short distance from the level of the rest of the apertural face; in other words, the indented surface of the apertural face does not open into this internal structure, if, indeed, it is hollow inside. According to Brotzen (1948, p. 97-103), who gives considerably more information on this structure in Alabamina, the base of the structure is open against the top of the underlying chamber.

The Red Bird specimens bear resemblance to two previously described species of Alabamina. A. dorsoplana (Brotzen) is similar in having a flat or slightly convex spiral side and quite convex umbilical side, but it differs importantly in having a much more protrudent peripheral extension of the final chamber ("tectum" in Brotzen's terminology), a higher aperture, and a more sharply angled periphery. A. australis australis Belford is similar in having a broadly rounded periphery, flat spiral surface, evolute spiral side, and aperture extending to the umbilicus. A point of difference is that Belford's specimens generally have five rather than six chambers in the final whorl. Belford (1960, p. 84) described the internal "tooth- plate" as solid in his subspecies, in contrast to the hollow nature of this structure as reported by Brotzen (1948). The extremely small size of this structure in the Red Bird specimens makes it impossible to determine whether it is hollow or solid.

No comparative specimens of $A$. australis australis were seen, but the excellent agreement of the Red Bird specimens with the descriptions and figures of this subspecies in almost every particular indicates that they are the same.

North and Caldwell (1964, p. 24, pl. 4, figs. 7a-c) described and illustrated a form they referred to as Eponides sp., which may be conspecific with $A$. australis australis, but there are sufficient points of difference in their description to make this synonymization tentative.

Occurrence and range.-A. australis australis has been reported only once previously, from Santonian beds of Australia (Belford, 1960, p. 84).

Genus AMMOBACULITES Cushman, 1910

Ammobaculites coprolithiformis (Schwager)

Plate 1, figure 11

Haplophragmium coprolithiforme Schwager, 1868, Benecke's Geogn.-paleont. Beiträge, v. 1, p. 654, pl. 34, fig. 3.

Ammobaculites coprolithiforme (Schwager). Cushman, 1927, Royal Soc. Canada Trans., 3d ser., v. 21, sec. 4, p. 130, pl. 1, figs. $6,7$.

Ammobaculites coprolithiformis (Schwager) Cushman and Deaderick, 1942, Cushman Lab. Foram. Research Contr., v. 18 , p. 51 , pl. 9 , fig. 9 .

Cushman and Deaderick, 1944, Jour. Paleontology, v. 18, no. 4 , p. 328 , pl. 50, fig. 2.

Description.-Test has a small initial coil of four to six chambers, later becomes uniserial, straight or very slightly arched, uniserial part consists of as many as six chambers, tapering gradually to the initial coil, has a short, fairly broad, terminal or slightly eccentric apertural extension. Chambers somewhat inflated, generally slightly higher than wide, as wide as high in some specimens, slightly overlapping, increasing very gradually and rather regularly in size as added, collapsed in many specimens. Sutures perpendicular or very nearly so to the axis of elongation, generally slightly to moderately depressed but considerably depressed in some specimens, indistinct where slightly depressed because of granularity of the wall. Wall rather thick, composed mostly of grains of intermediate to large size set close together in white to light-brown noncalcareous cement, surface smooth to moderately rough textured, nearly all grains are quartz; some specimens show considerable differences in grain size from one chamber to the next. Aperture 
a small subrounded opening at the end of the slightly produced apertural neck, neck missing on some specimens, presumably because of breakage, and aperture not discernible in many specimens.

Dimensions.-Specimens of average size are about $0.5 \mathrm{~mm}$ long and about $0.2 \mathrm{~mm}$ wide.

Remarks.-When preserved the apertural neck is short. In most specimens it tapers slightly from its broad base to its rather broad end. In other specimens the apertural neck is much narrower throughout and is composed of much finer grains. The Red Bird specimens assigned to Ammobaculites coprolithiformis are closely similar to specimens from the Marlbrook Marl and Brownstown Marl of Arkansas illustrated by Cushman and Deaderick (1942, pl. 9, fig. 9; 1944, pl. 50, fig. 2). Considerable latitude has been taken by Cushman and by other American workers in the Cretaceous in assigning specimens to this species. No detailed study of the variation shown by suites of specimens has been made. Unfortunately, the Red Bird specimens are too poorly preserved and too scarce to support such a study.

Among other species of Ammobaculites that have previously been reported from the Montana Group and equivalent rocks in North America exclusive of the gulf coast, $A$. fragmentarius Cushman most closely resembles the Red Bird specimens but differs in generally having more chambers per specimen and in being more tapered. A. texanus Cushman and $A$. stephensoni Cushman have much more pronounced initial coils than the Red Bird specimens, which have a single coil of four to six small chambers which externally resemble a partially compressed large proloculus. This latter characteristic and the frequent absence of the earliest part of the test make confusion between $A$. coprolithiformis and Reophax possible.

Occurrence and range.-Ammobaculites coprolithiformis has been reported from rocks of early to middle Campanian age from southwest Wyoming by Gauger (in Jones, 1953, p. 55) and, with question, from south-central Alaska by Bergquist (1961, p. 2005).

\section{Genus AMMOBACULOIDES Plummer, 1932}

\section{Ammobaculoides? sp.}

Plate 1, figure 4

Remarks.-A small group of poorly preserved specimens are questionably placed in Ammobaculoides. Most specimens consist only of the initial planispirally coiled stage, $0.15-0.18 \mathrm{~mm}$ in diameter, composed of five to seven chambers. Three specimens develop the linear stage (as many as five chambers) which appears to be loosely biserial throughout. The test is collapsed or distorted on all specimens and is composed of quartz grains, large in proportion to test size, embedded in a small amount of noncalcareous cement. This coarse grain size and the deformed condition of the specimens make it very difficult to observe sutures and chambers. The aperture was not observed.

\section{Genus ANOMALINOIDES Brotzen, 1942 \\ Anomalinoides pinguis (Jennings) \\ Plate 1, figure 5}

Anomalina pinguis Jennings, 1936, Bull. Am. Paleontology, v. 23 , no. 78 , p. 37 , pl. 5, fig. 1 .

Anomalinoides pinguis (Jennings). Brotzen, 1948, Sveriges geol. undersökning, Årsbok 42, no. 2, ser. C, no. 493, p. 86.

Tappan, 1962, U.S. Geol. Survey Prof. Paper 236-C, p. 199, pl. 58 , figs. $2-5$.

Bergquist, 1966, U.S. Geol. Survey Prof. Paper 302-D, p. $119,182,215,216$.

Description.-Test very low trochospiral, umbilical side convex, spiral side slightly convex in some specimens, especially smaller ones, planar to slightly concave in larger specimens, axial periphery rather abruptly rounded, has no keel, equatorial periphery smooth or has slightly to moderately pronounced indentations at the sutures, especially for the final three or four sutures, spiral side slightly evolute and has a central boss of clear shell material. Chambers wedge shaped, closely appressed, slightly to moderately inflated, eight to 10 in final whorl, increase regularly and gradually in size as added, except in some larger specimens where the final few chambers increase more abruptly in size over the preceding chambers. Sutures sometimes straight but usually slightly curved, commonly slightly oblique but occasionally radial, flush with the surface and strongly limbate in the early part of the final whorl of most specimens, less limbate and slightly depressed in the later part, coming together in a shallow depression on the umbilical side, joining the central boss of shell material on the spiral side. Wall granular in microstructure, with abundant coarse perforations many of which have been covered or filled in the earlier chambers of the final whorl. Aperture an interiomarginal opening extending from the umbilical side margin of the axial periphery to the edge of the boss of shell material on the spiral side and thence beneath the final three or four chambers, slightly arched and highest over the axial periphery 
of the test, much lower and more slitlike on the spiral side, with a thin slightly protrudent lip above.

Dimensions. - Greatest diameter of whorl about 0.38 $\mathrm{mm}$; maximum thickness parallel to coiling axis about $0.16 \mathrm{~mm}$.

Remarks.-In the very brief original description of Anomalina pinguis, Jennings (1936, p. 37) reported eight to nine chambers in the final whorl, whereas the Red Bird specimens have eight to 10 , and the aperture is described as embracing the margin of the test, no mention being made of a slit extending to the spiral side. In other respects, Jennings' description fits the Red Bird specimens very well, and the type figure is exactly similar to the spiral side view of these specimens. The poorly preserved plesiotype assigned to this species by Cushman (1944, p. 16) is about twice as large as the largest Red Bird specimen but is exactly similar in preserved morphologic characteristics. Anomalinoides pinguis is clearly distinct from other species of Anomalina and Anomalinoides reported from western interior, Canadian, or Alaskan deposits of Campanian or Maestrichtian ages.

Occurrence and range.-Anomalinoides pinguis has been reported from the Santonian and Campanian of northern Alaska by Tappan (1962) and Bergquist (1966). There have been no reports of this species from equivalent or younger Cretaceous rocks of the western interior of Canada. The species has been reported from the Corsicana Marl and Pecan Gap Chalk of the gulf coast Cretaceous by Cushman (1946, p. 156), from the Navesink and Mount Laurel Formations of New Jersey by Jennings (1936, p. 37), and from the Redbank Sand and the New Egypt Formation of Olsson (1959) in New Jersey by Olsson (1960, p. 51-52).

\section{Genus astacords de Montfort, 1808 \\ Astacolus jarvisellus Mello? \\ Plate 1, figure 6}

Marginulina jarvisi Cushman, 1938, Cushman Lab. Foram. Research Contr., v. 14, pt. 2, p. 35, pl. 5, figs. 17, 18.

Astacolus jarvisi (Cushman) [not Astacolus jarvisi Brotzen, 1936]. Trujillo, 1960, Jour. Paleontology, v. 34, no. 2, p. 317 , pl. 46 , fig. 2.

Astacolus jarvisellus Mello, 1969, U.S. Geol. Survey Prof. Paper 611 , p. 57, pl. 6, figs. $4 a, b$.

Remarks.-Two incomplete specimens have been assigned with question to this species. Characteristic features are the abrupt but unkeeled dorsal margin, the rather sharply rounded ventral margin which becomes progressively broader toward the apertural end, the partially coiled initial part involving the first four or five chambers, the extension of all but the last few chambers to the proloculus on the ventral side, and the smooth, unornamented wall having flush or slightly depressed and very slightly curved sutures. These specimens closely resemble the holotype of A. jarvisellus and specimens of this species from the Pierre Shale of north-central South Dakota (Mello, 1969 , p. 57), but the absence of the apertural area in both of the Red Bird specimens makes positive identification impossible.

Occurrence and range.-Mello (1969, p. 57) reported Astacolus jarvisellus from the lower part of the Mobridge Member of the Pierre Shale of late Campanian age. Cushman (1946, p. 63) reported this species from the Kemp Clay of Maestrichtian age in the gulf coast deposits.

\section{Genus BATHYSIPHON M. Sars, 1872}

Bathysiphon brosgei Tappan

Plate 1, figures 7-9

Bathysiphon brosgei Tappan, 1957, U.S. Natl. Mus. Bull. 215, p. 202, pl. 65, figs. 1-5.

Tappan, 1962, U.S. Geol. Survey Prof. Paper 236-C, p. 128, pl. 29, figs. 1-5.

Bergquist, 1966, U.S. Geol. Survey Prof. Paper 302-D, p. 104.

Mello, 1969, U.S. Geol. Survey Prof. Paper 611, p. 40, pl. 4, fig. 1.

Remarks.-The test is an open tube, broken at both ends in all the Red Bird specimens, that has considerable variation in width, wall thickness, and wall composition. Almost all specimens are compressed; the width of compressed specimens varies from 1.20 to $0.06 \mathrm{~mm}$. The walls vary in thickness from 0.18 to $0.01 \mathrm{~mm}$, but this thickness does not seem to be a direct function of specimen size, based on width, though the narrower specimens generally have thinner walls than the wider specimens. Many specimens have irregularly spaced constrictions in the test perpendicular or nearly so to the axis of elongation, and most specimens have a channellike longitudinal central depression due to secondary compression of the test. The texture of the walls varies from smoothly finished and almost glassy, with a very few discernible grains immersed in the matrix, to very rough, with numerous quartz grains cemented together by a minor amount of matrix. Some specimens seem to be transitional between these two end members, having walls composed mainly of matrix but studded with numerous large protrudent quartz grains. Another more common intermediate wall structure is composed of numerous moderate-sized grains set in a moderate amount of matrix and having a 
somewhat roughened surface texture. Although specimens of this species are not very common in the Red Bird samples, those available do show transitions between the wall compositions cited above. Paratypes of Bathysiphon brosgei in the U.S. National Museum collections, to which the Red Bird specimens were compared, show a variation in wall texture similar to that described for the Red Bird specimens except that none of the paratypes is so coarse grained as the coarsest grained Red Bird specimens.

The few specimens assigned to Bathysiphon vitta Nauss from the Red Bird samples are separated from specimens assigned to $B$. brosge $i$ Tappan on the basis of the black coating present at least to some degree on specimens of $B$. vitta. If this coating is secondary, as seems likely, then there seems to be no morphologic basis for distinguishing these specimens from $B$. brosgei. The separation is maintained here, however, pending more definitive evidence from larger assemblages. Tappan (1962, p. 128) separated specimens which she referred to $B$. vitta from those she assigned to $B$. brosge $i$ because $B$. brosge $i$ is more slender and has a somewhat more roughened surface. Her first criterion is faulty because the widest specimens of $B$. vitta must have had narrower early stages. Her second criterion may be valid, although, as it is a matter only of degree, it must be carefully evaluated. In summary, it seems to me that the criteria originally used to set $B$. brosge $i$ apart from $B$. vitta are open to question and that the reality of $B$. brosge $i$ as a species distinguishable from $B$. vitta deserves further study. Samples and relative abundances.-

Fine-grained wall : 10-S, 11-X, 26-RR, 27-VR, 33-VR, 44-S, 54-R, 55-S, 58-VR, 61-VR

Medium-grained wall : $31-\mathrm{X}, 36-\mathrm{X}, 45-\mathrm{VR}, 46-\mathrm{X}$, 52-S, 53-S, 57-S, 71-RR, 74-S

Coarse-grained wall : $39-\mathrm{X}, 60-\mathrm{R}, 62-\mathrm{S}, 65-\mathrm{S}, 66-\mathrm{VR}$, $73-\mathrm{X}$

Wall-type indeterminate: $3-\mathrm{X}, 4-\mathrm{S}, 15-\mathrm{VR}, 17-\mathrm{X}$, $35-\mathrm{X}, 37-\mathrm{X}$

Occurrence and range.-Bathysiphon brosgei has been reported from rocks of early Albian to late Campanian ages in northern Alaska by Tappan (1962, p. 128). It was also reported from northern Alaska by Tappan (1957, p. 202) and Bergquist (1966, p. 104) and from the late Campanian and early Maestrichtian parts of the Pierre Shale of South Dakota by Mello $(1969$, p. 40$)$. The very brief descriptions and poor figures given by LeRoy and Schieltz (1958, p. 2453, fig. 8) for $B$. arenacea Cushman, $B$. aff. carapitanus Hedberg, and $B$. eocenica Cushman and Harris from the Sharon Springs Member of the Pierre Shale in
Colorado may well represent variations of $B$. brosgei as here recognized.

\section{Bathysiphon vitta Nauss}

Plate 1, figure 10

Bathysiphon vitta Nauss, 1947, Jour. Paleontology, v. 21, no. 4, p. 334 , pl. 48 , fig. 4 .

North and Caldwell, 1964, Saskatchewan Research Council, Geology Div. Rept. 5, p. 10, pl. 1, figs. 1a-c.

Wall, 1967b, Research Council Alberta Bull. 20, p. 38, pl. 7, figs. 4-7.

Remarks.-Six specimens from three samples are placed in this species. The specimens are compressed tubes having thick walls composed of minute grains set in a grayish-white matrix. There are few clearly distinct grains, but many smaller objects are thought to be grains, although they may be small rugosities composed of matrix. Two of the specimens are markedly wrinkled, probably a result of the distortion that caused their compression, and the illustrated specimen has an indistinct constriction near the middle. The most striking characteristic of these specimens is a dark surface coating. All specimens placed in this species have at least a trace of this coating, and one specimen is completely coated except at the ends and along cracks. Close examination of these coated surfaces shows that the coating is composed of many very fine blebs of brownish-black material, perhaps hydrotroilite. Along the cracks and at the broken ends of the specimens, this coating can be seen to be entirely surficial, the fine blebs being only on the outer surface of the test. In view of the surficial and probably secondary nature of this coating, its presence is probably not a valid morphologic criterion for separation of this species from Bathysiphon brosgei Tappan. However, because of the extreme morphologic simplicity of this genus and the variability in morphologic characters displayed by its species, I hesitate to synonymize $B$. vitta on the chance that the black coating was originally deposited by the organism. When large suites of specimens become available, the constancy of this black coating should be carefully evaluated. It should be noted that North and Caldwell (1964, p. 10) assigned many uncoated specimens to this species and did not regard this character as of diagnostic value.

Dimensions of largest specimen.-Length (incomplete), $0.73 \mathrm{~mm}$; width, (partially crushed), $0.41 \mathrm{~mm}$.

Occurrence and range.-Bathysiphon vitta was originally reported by Nauss $(1947$, p. 334) from the late Santonian and early Campanian Lea Park Shale of east-central Alberta, Canada. It has since been re- 
ported from the same formation in south-central Saskatchewan (North and Caldwell, 1964, p. 10) and from Albian beds in northern Alaska (Tappan, 1962, p. 128).

\section{Genus BULIMINA d’0rbigny, 1826}

Bulimina kickapooensis Cole

Plate 1, figure 14

Bulimina kickapooensis Cole, 1938, Florida Dept. Conserv., Geol. Dept. Bull. 16, p. 45, pl. 3, fig. 5.

Bulimina kickapoocnsis Cole var. pingua Cushman and Parker, 1940, Cushman Lab. Foram. Research Contr., v. 16, pt. 2, p. 44, pl. 8, figs. 13, 14.

Bulimina kickapooensis Cole. Mello, 1969, U.S. Geol. Survey Prof. Paper 611, p. 75, pl. 8, figs. 14, 15.

Remarks.-This species is represented by fewer than 10 whole specimens preserving original shell material, all of which are small and microspheric, and by about 30 specimens which are either crushed, incomplete, or preserved as internal molds. Many of the second group can only be referred to this species with question. Bulimina kickapooensis is much more abundantly represented in the Pierre Shale of north-central South Dakota, as described by Mello (1969, p. 75). The better preserved Red Bird specimens are easily accommodated within the ranges of variation shown by the South Dakota specimens.

Occurrence and range.-Cushman (1946, p. 123) reported Bulimina kickapooensis from beds of Austin, Taylor, and Navarro ages. In the western interior and Canada, it has been reported from the Hilliard Shale of southwest Wyoming of inferred middle and upper Campanian age (Gauger, in Jones, 1953, p. 79, pl. 9, fig. 16) ; from the Gregory Member of the Pierre Shale in North Dakota of middle Campanian age (Mello, in Gill and Cobban, 1965, p. A13) ; from the Virgin Creek, Mobridge, and Elk Butte Members of the Pierre Shale in South Dakota of late Campanian and early Maestrichtian age (Mello, 1969, p. 75) ; and from the Bearpaw Formation in southwestern Saskatchewan and southern Alberta of middle to late Campanian age (Loranger and Gleddie, 1953, fig. 3, p. 166).

\section{Genus BULIMINELIA Cushman, 1911 \\ ?Buliminella carseyae Plummer \\ Plate 1, figures 12,13}

Buliminella carseyae Plummer, 1931, Texas Univ. Bull. 3101, p. 179 , pl. 8 , fig. 7 .

Description.-Test trochospiral, elongate, composed of as many as four whorls of three to $4 \frac{1 / 2}{2}$ chambers per whorl, most tests abruptly increasing in size after the first or second whorl; earliest part has $31 / 2-41 / 2$ chambers per whorl, final one to $1 \frac{1}{2}$ whorls generally greatly enlarged and composed of three to $31 / 2$ chambers. Chambers of the final whorl inflated, overlapping much of the preceding whorl, each chamber embracing about half the preceding chamber, all chambers increasing regularly and moderately abruptly in size except for a very abrupt increase in size and degree of inflation in one whorl in most specimens. Sutures distinct except in earliest part, slightly depressed, intercameral sutures gently sinuous, spiral suture somewhat interrupted at chamber junctions but has a readily discernible spiral pattern. Walls smooth, generally glassy, unornamented, finely perforate, rather thick and opaque, although the final few chambers of some specimens are translucent and much thinner, apparently granular in microstructure. Aperture a curved, slot-shaped to oval opening extending from the base of the final chamber to one-half to two-thirds the height of the very low apertural face; generally set deeply in the apertural face and overhung at the top by the upper one-half to one-third of the apertural face, has a slightly thickened periphery on most specimens. Toothplate simple, a thick and apparently solid structure which extends from the inner or axial side of the aperture to the inner side of, but not into, the aperture of the penultimate chamber, has no surficial expression.

Dimensions.-Maximum length, about $0.6 \mathrm{~mm}$. Ratio of maximum length to maximum breadth ranges from 1.44: 1 for small specimens to $1.13: 1$ for large specimens.

Remarks.-The Red Bird specimens are slightly to moderately broader than topotypes of Buliminella carseyae Plummer (Cushman colln. 40331), and the intercameral sutures of the final whorl are more nearly vertical than in the topotypes. Also, the final whorl in some of the Red Bird specimens is composed of three chambers, whereas none of the topotypes has a final whorl of less than $31 / 4$ chambers. Similarities which suggest that the Red Bird specimens are conspecific with $B$. carseyae are general test shape, the quantum increase in chamber size within a single whorl, and the possession of $31 / 2-41 / 2$ chambers in the early whorls. To a lesser degree, the Red Bird specimens resemble the type specimens of Bulimina reussi Morrow navarroensis Cushman and Parker, but they differ in being considerably larger and more abruptly enlarging than the types.

The granular nature of the test wall was noted for all three specimens that were crushed and examined under the polarizing microscope. Loeblich and Tappan (in Loeblich, Tappan, and others, 1964, p. C543, C545) stated that the walls of Büliminella and Praebulimina 
are radially built. The Red Bird specimens may have been recrystallized, but it is also possible that this character is not of the high diagnostic value inferred for it.

The toothplate of the Red Bird species is much more like that diagrammed for Praebulimina sp. by Loeblich and Tappan (in Loeblich, Tappan, and others, 1964, p. C544, fig. 428-4) than that diagrammed for Buliminella elegantissima d'Orbigny (Loeblich, Tappan, and others, 1964, p. C542, fig. $426-4 a, b)$. Toothplates could not be observed in the topotypes owing to chamber fillings.

Tentative assignment is made to Buliminella carseyae based on the resemblances noted above between the few well-preserved Red Bird specimens and the topotypes examined.

Occurrence and range.-Applin (1933, p. 219) listed Buliminella carseyae from the Pierre Shale of Campanian and early Maestrichtian ages in South Dakota. Loranger and Gleddie (1953, fig. 3, p. 166) listed this species from the Bearpaw Formation of probably early Maestrichtian age in southwestern Saskatchewan and southern Alberta. Searight (1938, p. 135) listed this species from his (1937) Sully Member of the Pierre Shale of middle Campanian age in South Dakota. According to Cushman (1946, p. 120), B. carseyae is found in beds of Austin, Taylor, and Navarro ages in the Gulf Coastal Plain.

\section{Genus CAUCASINA Khalilov, 1951}

Caucasina vitrea (Cushman and Parker)

Plate 2, figure 1

Buliminella vitrea Cushman and Parker, 1936, Cushman Lab. Foram. Research Contr., v. 12, p. 7, pl. 2, fig. 4.

Caucasina vitrea (Cushman and Parker). Tappan, 1962, U.S. Geol. Survey Prof. Paper 236-C, p. 188, pl. 49, figs. 23-25. Mello, 1965, in Gill and Cobban, U.S. Geol. Survey Prof. Paper 392-A, p. A13 [list].

Aeolostreptis vitrea (Cushman and Parker). Bergquist, 1966, U.S. Geol. Survey Prof. Paper 302-D, p. 145, 160, 176 [lists].

Description.-Test in early part composed of two to $21 / 2$ whorls consisting of six to eight low chambers per whorl arranged in a very low trochoid spire; above this early part the chambers increase more abruptly in size, and especially in height, as added, and the number per whorl abruptly decreases to three within about $11 / 2$ whorls; the final part is composed of one to two, and usually less than $11 / 2$, whorls of three chambers each in a bulimine arrangement. Chambers in initial low trochoid part very small in comparison with later chambers, increasing gradu- ally and regularly in size as added, the two to $2 \frac{1}{2}$ whorls which they compose forming a bun-shaped base to the test; chambers abruptly become higher but increase little in width in the transitional and bulimine whorls, finally from $11 / 2$ to two times as high as wide in bulimine stage, closely appressed throughout, becoming slightly to moderately inflated in bulimine stage. Sutures slightly to moderately depressed inbulimine and transitional whorls, flush or very slightly depressed in earlier part, gently curved, oblique in low trochoid stage. Wall granular in microstructure, rather finely perforate, perforations fairly widely spaced. Aperture ovate to narrow and elongate, set in a triangular depression formed partly by the junction of the three final chambers and partly by an indentation of the apertural face of the final chamber, bordered on one side by a slightly protrudent, thin lip and on the other side by the central area of the triangular depression which is apparently filled with extraneous material in all specimens. Attempts at dissection of the final chamber to determine whether or not an internal toothplate is present yielded no information.

Dimensions.-Typical specimens are approximately $0.25 \mathrm{~mm}$ long and $0.13 \mathrm{~mm}$ in greatest width.

Remarks.-The Red Bird specimens are very closely similar to the holotype and especially the paratypes of Caucasina vitrea, and there is no doubt that they belong in this species.

The Red Bird specimens are quite well preserved, but all appear to have a secondary filling of some kind in the central part of the triangular depression in which the aperture is set. Three specimens were partially dissected in the hope of discovering whether or not a toothplate was present, but the presence of extraneous matter within the final chambers, coupled with the problems in seeing such a tiny object if it were present, made the observations equivocal. The plane of coiling of the low trochoid part of the test is slightly to moderately oblique to the axis of elongation of the later part of the test in some specimens, but in most specimens it is perpendicular to this axis.

Occurrence and range.-This distinctive species has been reported from the Gregory Member of the Pierre Shale in North Dakota (Mello, in Gill and Cobban, 1965, p. A13) and from the Schrader Bluff Formation of northern Alaska (Tappan, 1962, p. 188; Bergquist 1966$, p. $145,160,176)$. The range of this species is from Santonian to Maestrichtian in the gulf coast (Cushman, 1946, p. 119). It occurs in Campanian age strata in the western interior and Alaska. At Red Bird 
the species occurs as a scarce form in two samples from the Red Bird Silty Member.

Genus CIBICIDES de Montfort, 1808

Cibicides sp. aff. C. beaumontianus (d'Orbigny)

Plate 2, figure 3

Truncatulina beaumontiana d'Orbigny, 1840, Soc. géol. France Mém., 1st ser., v. 4, p. 35, pl. 3, figs. 17-19.

Cibicides beaumontianus (d'Orbigny). Brotzen, 1936, Sveriges geol. undersökning, ser. C, no. 396, p. 188.

Description.-Test trochoid, composed of as many as $21 / 2$ whorls, spiral side planar to moderately concave, partially evolute, umbilical side subhemispherical, has a shallow, dimplelike umbilicus, involute, equatorial periphery slightly to moderately lobulate, axial periphery abruptly rounded to subacute. Chambers five to seven in final whorl, slightly to moderately inflated, slightly overlapping, increasing regularly and rather abruptly in size as added, especially parallel to axis of coiling; sutures moderately oblique to nearly radial on spiral side, slightly to moderately convex toward the apertural end, becoming slightly limbate toward the spiral suture, on umbilical side radial at the umbilicus, straight or slightly convex toward the apertural end. Wall coarsely perforate, smooth to somewhat roughened in texture, apparently granular in microstructure. Aperture a low-arched interiomarginal opening originating on the umbilical side from one-fourth to one-half the distance from the periphery to the umbilicus and continuing over the periphery and beneath the final chamber on the spiral side, bordered above by a somewhat thickened and somewhat protrudent rim, spiral side parts of the apertures, composed of as many as four of the preceding chambers, remain open and are separated only at the sutures.

Dimensions.-Maximum diameter of available specimens, $0.39 \mathrm{~mm}$; maximum thickness parallel to the axis of coiling, $0.22 \mathrm{~mm}$.

Remarks.-All Red Bird specimens differ from typical Cibicides beaumontianus in having a rounded rather than an acute axial periphery, in having five to seven chambers in the final whorl instead of seven to nine, and in failing to attain large size. In other respects, such as general test shape, chamber shape and rate of enlargement, nature of sutures and aperture, and size of perforations, the Red Bird specimens are very similar to typical $C$. beaumontianus. More specimens are needed before a decision can be made whether they represent a distinct species or simply a variant form of $C$. beaumontianus.
Occurrence and range-Cibicides beaumontianus has not previously been recorded from rocks of Campanian or Maestrichtian age in the western interior, Canada, or Alaska. In the Gulf Coastal Plain deposits, it occurs in rocks of Navarro and Taylor ages (Cushman, 1946, p. 160).

\section{Genus Dewtalina Risso, 1826}

Dentalina basiplanata Cushman

Plate 2, figure 8

Dentalina basiplanata Cushman, 1938, Cushman Lab. Foram. Research Contr., v. 14, pt. 2, p. 38, pl. 6, figs. 6-8.

Description.-Test uniserial, slightly arched, composed of as many as eight chambers, slightly compressed in early part (first three or four chambers) except for the globular proloculus, unornamented. Chambers slightly compressed in the plane of curvature in the early part, later globular, increasing slowly in size as added, closely appressed in the early part, becoming progressively less closely appressed as added; final chamber may be reduced in size. Sutures moderately oblique to the axis of elongation in early part, becoming more nearly perpendicular toward the apertural end, moderately limbate toward the concave side, becoming slightly limbate toward the convex side. Wall has radial microstructure. Aperture radial, at the end of a slightly produced neck, toward the concave side of the test.

Dimensions.-For complete specimens the maximum length is $1.01 \mathrm{~mm}$; maximum breadth, $0.17 \mathrm{~mm}$; and maximum thickness, $0.15 \mathrm{~mm}$. For incomplete specimens, maximum breadth is $0.26 \mathrm{~mm}$, and maximum thickness is $0.25 \mathrm{~mm}$.

Remarks.-The illustrated specimen is apparently aberrant because the final chamber is reduced in size and has two irregular apertures. The normal radial and produced aperture is preserved on other specimens. The more complete Red Bird specimens correspond very closely to the type specimens of Dentalina basiplanata. Assignment of the shorter partial specimens is less certain. Species of the genus Dentalina are often quite variable in their morphology, and in view of the fact that there have been no attempts at detailed quantification of variability for most species, variants of $D$. basiplanata may have been recorded in Canada, Alaska, and the western interior under different specific names.

Occurrence and range.-Dentalina basiplanata has been reported from the Frontier Formation of inferred early Campanian age in northeastern Utah (Peterson, in Jones, 1953, p. 35, 36, pl. 1, figs. 22, 23), 
from the Lea Park Formation of early Campanian age in south-central Saskatchewan (North and Caldwell, 1964, p. 18, pl. 3, fig. 7), and from the Schrader Bluff Formation of Santonian and Campanian ages in northern Alaska (Tappan, 1962, p. 174, 175, pl. 45, fig. 17; Bergquist, 1966, pl. 14). Cushman (1946, p. 68, pl. 24, figs. 1-6) reported it from beds of Navarro and Taylor ages in the Gulf Coastal Plain.

\section{Dentalina cf. D. gracilis d'Orbigny}

Plate 2, figure 9

Dentalina gracilis d’Orbigny, 1840, Soc. géol. France Mém., 1st ser., v. 4 , p. 14, pl. 1, fig. 5 .

Remarks.-Four partial specimens are tentatively assigned to this species on the basis of slender and gently curved test shape, slightly oblique and slightly depressed sutures, and slightly elongate chamber shape. They are similar in these respects to a plesiotype of Dentalina gracilis illustrated by Cushman (1946, pl. 23, fig. 4).

Occurrence and range.-Dentalina gracilis has been reported from the Gregory Member of the Pierre Shale of middle Campanian age in North Dakota (Mello, in Gill and Cobban, 1965, p. A12, A13), from the Campanian part of the Frontier Formation in northeastern Utah by Peterson (in Jones, 1953, p. 34, pl. 1, figs. 20, 21), from the Campanian part of the Hilliard Formation in southwestern Wyoming by Gauger (in Jones, 1953, p. 70, pl. 8, figs. 3-6), from the middle Campanian part of the Matanuska Formation in south-central Alaska (Bergquist, 1961, p. 2004), and from the late Campanian and early Maestrichtian part of the Pierre Shale in South Dakota by Mello $(1969$, p. 59, pl. 6, figs. 10a, b). The species is reported from beds of Austin, Taylor, and Navarro ages in the Gulf Coastal Plain deposits (Cushman, 1946, p. 65, $66)$.

\section{Dentalina legumen Reuss}

Plate 2, Figure 7

Dentalina legumen Reuss, 1851, Haidinger's Naturw. Abh., v. 4, p. 10, pl. 1, fig. 14 .

Remarks.-A single well-preserved megalospheric specimen of this species, consisting of four chambers plus the bulbous proloculus, was found. The radiate aperture is atop a fairly short extension of the upper surface of the last chamber and is marginal in position. The apertural side of the test is straight, and the opposite side is slightly concave because of the very slight increase in size of the chambers as added. The sutures are moderately oblique and very slightly depressed.
Occurrence and range.-Dentalina legumen has been reported from the early Campanian part of the Lea Park Formation in south-central Saskatchewan by North and Caldwell $(1964$, p. 19, pl. 3, fig. 8), with question from the Gregory Member of the Pierre Shale of middle Campanian age in North Dakota by Mello (in Gill and Cobban, 1965, p. A12, A13), and from the late Campanian and early Maestrichtian part of the Pierre Shale in South Dakota by Mello (1969, p. 60, pl. 6, fig. 11). Cushman (1946, p. 65, pl. 23, figs. 1,2) reported this species from beds of Austin, Taylor, and Navarro ages in the Gulf Coastal Plain deposits.

\section{Genus DOROTHIA Plummer, 1931}

\section{Dorothia smokyensis Wall}

Plate 2, figures 10, 11

Dorothia smokyensis Wall, 1960. Research Council Alberta Bull. 6, p. 23-24, pl. 4, figs. 22-28.

?Spiroplectammina bentonensis Carman, 1929, Jour. Paleontology, v. 3, p. 311, pl. 34, figs. 8, 9.

Gaudryina bentonensis (Carman). Mello, 1969, U.S. Geol. Survey Prof. Paper 611, p. 48, pl. 4, figs. 11a, b.

Description.-Test elongate, straight or slightly arched, multiserial in earliest part, almost immediately becoming triserial, followed by a biserial stage in which the chambers show a progressive tendency toward uniseriality; true uniserial condition achieved in a small number of Red Bird specimens; early triserial part may constitute as little as one-seventh the length of the test in large specimens, composed of two or three whorls, tapering toward the initial end, generally triangular in end view but has broadly rounded angles, appearing oval in some specimens, sides parallel or nearly so above triserial part; early part of biserial part composed of two or three pairs of rather closely appressed chambers, slightly twisted, composing as little as one-third the length of most large specimens, later part of biserial part more loosely biserial, composed of as many as eight chambers, which become progressively less closely appressed as added, eventually achieving a semiuniserial condition in which the chambers are arranged like alternating wedges. Specimens attaining a true uniserial condition have as many as five uniserial chambers, and in these specimens the loose biserial part, and sometimes the whole biserial part, is considerably reduced although still present. Chambers in triserial part inflated, closely appressed, increasing rather abruptly in size as added, thus imparting a subconical appearance to this part of the test; chambers inflated and somewhat 
less closely appressed in older part of biserial part, increasing very little in size as added; chambers inflated and even less closely appressed in younger part of biserial part, increasing gradually in size as added, and progressively approach uniseriality; in uniserial part chambers inflated, subglobular, moderately overlapping; transition from older closely appressed biserial part to loosely appressed biserial part takes place rather abruptly. Sutures in triserial part slightly if at all depressed, often indistinct, slightly to moderately depressed in early biserial part and deeply depressed between the more loosely arranged chambers of the later biserial part and in the uniserial part. Wall a mosaic of fine- and moderate-sized grains set in a moderate amount of cement, rather smoothly finished, moderately coarse grained and roughly finished in a few specimens; nearly all grains are quartz, but many appear to be dark because of the absorption of light by the dark chamber fillings; wall commonly collapsed when chambers not filled. Aperture in uniserial part a terminal, slightly depressed, rounded opening, in loosely appressed biserial part subterminal to terminal, in a number of specimens surrounded by several moderately protrudent quartz grains; aperture in the early biserial stage observed on only one specimen where it is an irregular interiomarginal arched opening along the axis of the test; nature of aperture in triserial part unknown because of absence of specimens consisting solely of this part.

Dimensions.-Typical Red Bird specimens are approximately $0.75 \mathrm{~mm}$ long and $0.18 \mathrm{~mm}$ in greatest width; the largest specimens are about $1.63 \mathrm{~mm}$ long and $0.26 \mathrm{~mm}$ in greatest width.

Remarks.-Most of the Red Bird specimens are indistinguishable from Dorothia smokyensis as described by Wall $(1960$, p. 23$)$. Comparative specimens kindly sent to me by Wall show the loose biserial chamber arrangement and subterminal to terminal aperture characteristic of most Red Bird specimens. Wall reports at least four chambers per whorl in the early part of his species, which subsequently decrease to three. This character is impossible to see on most Red Bird specimens because of the extremely small size of the chambers and the rugosity of the wall, but perhaps also in part because of the absence of multiserial chambers in megalospheric (?) individuals. However, the multiserial arrangement is clearly present in some specimens.

Some of the Red Bird specimens differ from the type description of $D$. smokyensis in possessing a substantial uniserial part. This may represent an evolutionary advance, or gerontic development. Subspecies should be recognized if future work shows consistent stratigraphic or geographic separation of the Red Bird and Canadian forms.

The Red Bird specimens were initially assigned to Spiroplectammina bentonensis Carman before the early part of the test was recognized to be multiserial. Because of compression, the type specimens of $S$. bentonensis are very poorly preserved, and it was impossible to observe whether a multiserial part is present. They do show an early triserial chamber arrangement, followed by a closely appressed biserial part, and a later more loosely appressed biserial part as described for the Red Bird specimens. The aperture is indistinguishable on the types, but on the holotype the terminal part of the final chamber is truncated, as would be expected if the aperture were terminal or subterminal. This truncate appearance of the final chamber is well displayed by Cushman's (1946, pl. 7, fig. 15a) figure of the holotype. The tendency toward uniseriality is well displayed by a plesiotype illustrated by Cushman (1946, pl. 7, fig. 16) from the Bonham Marl of Texas. It seems likely that $S$. bentonensis and D. smokyensis are conspecific, and a tentative synonymization of these names is made here. The poor condition of the types of $S$. bentonensis, however, precludes the positive establishment of conspecificity.

Occurrence and range.-Because of the commonly distorted or crushed nature of specimens, it seems likely that this species has been reported under names other than those recognized in this paper. Dorothia smokyensis was originally described from the Kaskapau and Puskwaskau Shales of Alberta by Wall (1960, p. 24). It has since been reported by Wall and Germundson (1963, p. 339-343) from beds of the Alberta Group ranging in age from early Coniacian to early Campanian and by Bergquist (1966, p. 216) from beds of Santonian and Campanian ages in northern Alaska. Wall (1967b, p. 81) reported it from beds of Turonian to Campanian ages in the Rocky Mountain foothills, and he (Wall, 1967a, p. 190) reported it from beds of Campanian age in the northern Rocky Mountain foothills. Questioned identifications of the species, as Gaudryina bentonensis were made by Mello (in Gill and Cobban, 1965, p. A13) from the Gregory Member of the Pierre Shale in North Dakota and by Bergquist (1961, p. 2005) from the Matanuska Formation of south-central Alaska. Mello (1969, p. 48) reported it from the upper part of the Pierre Shale in South Dakota. Spiroplectammina bentonensis was originally reported by Carman from the Benton Shale near Centennial, Wyo. 
Genus EOUVIGERINA Cushman, 1926

Eouvigerina sp. 1

Plate 2, figure 2

Remarks.-A single specimen, composed of five inflated subglobular chambers in the biserial part and an undetermined number of chambers in the early part, is given this designation. The walls are hispid as in Eouvigerina hispida Cushman, but the holotype and paratypes of this species are more slender and show a greater tendency toward uniseriality. Two arched carinae placed high on the sides of the final chamber tend to converge toward the axis of elongation of the test, as in Eouvigerina aspera inflata Marie from the Pierre Shale in north-central South Dakota (Mello, p. 1969, p. 74), but the absence of these carinae on the earlier chambers seems to set the specimen apart from $E$. aspera inflata, although it may represent an earlier evolutionary stage of this species. The aperture was presumably located at the end of an apertural neck, which has been broken off flush with the upper surface of the last chamber.

\section{Genus FISSURINA Reuss, 1850}

\section{Fissurina sp. A}

Plate 2, figure 6

Fissurina sp. A Perlmutter and Todd, 1965, U.S. Geol. Survey Prof. Paper 483-I, p. I16, pl. 3, figs. 6a, b.

Fissurina sp. A. Mello, 1969, U.S. Geol. Survey Prof. Paper 611 , p. 67 , pl. 1 , figs. 6,7 ; pl. 7 , figs. 14a, b.

Remarks.-A single perfectly preserved specimen of this species was found. The species has been described from the Pierre Shale of South Dakota by Mello (1969) and from the Monmouth Group of New York by Perlmutter and Todd (1965, p. I16, pl. 3, fig. 6a, b). Characteristic features are the somewhat compressed, saclike test shape, the presence of four curved submarginal thickened areas, a small basal knob, and the wide slot-shaped aperture. This aperture narrows toward the interior into an entosolenian tube which extends about one-half the length of the test and ends in a somewhat flaring, saddle-shaped opening.

Occurrence and range.-The only previous references to this species are those cited in the synonymy, from the Monmouth Group undifferentiated in Long Island, N.Y., and from the late Campanian and early Maestrichtian part of the Pierre Shale in South Dakota. The species remains unnamed for lack of sufficient specimens on which to base the erection of a new species.

\section{Genus Frondrcularia Defrance, 1826}

Frondicularia watersi Cushman

Plate 3, figure 7

Frondicularia watersi Cushman, 1936, Cushman Lab. Foram. Research Contr., v. 12, p. 14, pl. 3, figs. 14, 15.

Description.-Test much compressed, consisting of six chambers and a megalospheric proloculus, about $21 / 2$ times as long as broad; lateral peripheries truncate, thickened but not keeled except on apertural neck; greatest breadth just above the base, tapering gradually toward the apertural end; test has a stout basal spine beneath the proloculus and a rather thick, fairly long apertural neck. Chambers chevron shaped, very slightly inflated, increase gradually in size as added, except for the arms of the chevron, which increase abruptly in length as added; first two chambers nearly completely embrace the proloculus, later chambers extend successively slightly less far back, but all reach back at least as far as the middle of the proloculus. Sutures thick, convex outward to sigmoidal, flush with the surface. Wall very finely perforate, moderately thick, semitransparent, unornamented, smooth except for random, very small flakes or chips of quartz (?) or calcite (?) adhering to the surface. Aperture not observed, located at the tip of the apertural neck, which is broken off in this specimen.

Remarks.-A single well-preserved specimen of Frondicularia watersi was found. In test shape, chamber shape and arrangement, and presence of a basal spine, apertural neck, and truncate peripheries, it corresponds very well to the type specimens of this species. It differs in being megalospheric-and thus lacks the early flabelline chamber arrangement of the microspheric type specimens-and in being less strongly compressed than the types.

Occurrence and range.-Frondicularia watersi has not previously been reported from Canada, Alaska, or the western interior. Cushman (1946, p. 91) reported it from beds of lower Navarro and Taylor ages in the Gulf Coastal Plain deposits and considered it to be characteristic of beds of Taylor age.

\section{Genus GAUDRYINA d'Orbigny, 1839 \\ Gaudryina watersi (Cushman) \\ Plate 3, figure 3}

Plectina watersi Cushman, 1933, Cushman Lab. Foram. Research Contr., v. 9, pt. 3, p. 57, pl. 7, figs. 1a-d.

Gaudryina watersi (Cushman). Mello, 1969, U.S. Geol. Survey Prof. Paper 611, p. 47, pl. 4, figs. 9a-c.

Remarks.-A small group of rather badly distorted specimens is placed in this species. Most specimens 
consist only of an untwisted triserial part composed of as many as five whorls, but a few specimens develop the biserial stage. The wall is composed of numerous very fine grains and a scattering of larger grains set in considerable cement. Despite the poor preservation, these specimens compare sufficiently well to the type specimens of Plectina watersi to allow fairly confident assignment to this species.

Occurrence and range.-Gaudryina watersi has been reported from the late Campanian and early Maestrichtian part of the Pierre Shale in South Dakota (Mello, 1969, p. 47). It has been reported by Cushman (1946, p. 47) from beds of Navarro age in the Gulf Coastal Plain.

\section{Genus GLOBIGERINeLLOIDES Cushman and ten Dam, 1948}

Globigerinelloides prairiehillensis Pessagno

Plate 2, figure 5

Globigerinelloides prairiehillensis Pessagno, 1967, Palaeontographica Americana, v. 5, no. 37, p. 277, pl. 60, figs. 2,3 ; pl. 83 , fig. 1 ; pl. 90 , figs. $1-2,4$; pl. 97 , figs. 3,4 .

Description.-Test planispiral, slightly to moderately evolute, biumbilicate, equatorial periphery lobulate, axial periphery broadly rounded. Chambers globular, not closely appressed, increasing regularly and gradually in size as added, six or seven in the final whorl; final chambers in some specimens not quite symmetrical with regard to equatorial periphery. Sutures moderately to considerably depressed, straight and radial in side view. Wall has radial microstructure, thin, translucent, covered with fine papillae; in many specimens the papillae are finer on the last one or few chambers. Aperture interiomarginal, a moderately high-arched opening which may extend from one-half to nearly the full chamber height toward the umbilici, has a thin, short, forward-projecting lip above in the equatorial plane which progressively widens toward the umbilici into two slender flanges. These flanges may continue for a short distance below the base of the chamber as umbilically and posteriorly directed tonguelike projections. These extensions are imbricated with those of earlier chambers part way around the umbilicus on well-preserved specimens, but no relict apertures could be seen beneath them on any specimen.

Dimensions.-Maximum diameter in the plane of coiling, $0.33 \mathrm{~mm}$; maximum width of final chamber parallel to axis of coiling, $0.22 \mathrm{~mm}$. Ratio of maximum diameter in plane of coiling to maximum diameter of final chamber parallel to axis of coiling is $2: 1$ in small- to medium-sized specimens but decreases in larger specimens.

Remarks.-In discussing Biglobigerinella biforaminata (Hofker) (Mello, 1969, p. 96), I stated

Nothing of a factual nature can be added here with respect to the controversy over the reality and the taxonomy of the genus Biglobigerinella. For the present the generic concept of Biglobigerinella is useful, even if polyphyletic, in that it encompasses forms with obvious morphologic similarities. If future work establishes the polyphyletic nature of the genus, then more subtle morphologic distinctions will have to used to place the species of Biglobigerinella in other genera.

Pessagno (1967, p. 274-279) has given further evidence of the polyphyletic nature of Biglobigerinella. However, the more subtle morphologic distinctions necessary for assignment of specimens have not been sufficiently developed by Pessagno for some species that he describes. The specimens I described as Biglobigerinella biforaminata (Hofker) (Mello, 1969, p. 95). fit Pessagno's description of Globigerinelloides multispina (Lalicker), but they do not correspond closely to the type specimens of $G$. multispina (Lalicker) which are much more robust, much more involute, and more coarsely spinose. Pessagno has not adequately documented the enlargement of the definition of $G$. multispina which he advocated in his synonymy and discussion. The need for such documentation is especially acute because of the close morphologic similarity between $G$. multispina and other species of Globigerinelloides.

Pessagno proposed a phylogenetic lineage beginning with $G$. asperus (Ehrenberg) to $G$. prairiehillensis Pessagno to $G$. multispina (Lalicker). This lineage is characterized by an increase in rate of chamber enlargement, overall test size, and degree of involution of the test and by a decrease in apertural height. In addition, G. multispina develops bipartite apertures and paired chambers in larger specimens. The Red Bird specimens correspond to the type description and type specimens of $G$. prairiehillensis, except that they are about 10 percent smaller than the types, and they typically have medium- to high-arched apertures. The low-arched aperture described for the species is present in only a few specimens. The stage in phylogenetic development represented by the Red Bird specimens is matched in the ontogeny of the specimens I described from South Dakota, and given the discriminatory criteria presented by Pessagno, it is impossible to separate the Red Bird specimens from mediumsized South Dakota specimens. Because none of the Red Bird specimens develops the double aperture described as characteristic of $G$. multispina, they are 
here placed in G. prairiehillensis. The members of this lineage must be more intensively studied in order to seek out, if possible, morphologic criteria that are independent of the phylogenetic development of the lineage, yet characteristic of the species recognized within the lineage.

Occurrence and range.-Globigerinelloides prairiehillensis was originally reported from rocks of late Santonian to early Maestrichtian age in the Gulf Coastal Plain (Pessagno, 1967, p. 278). Specimens referred to Globigerina aspera or Globigerinella aspera and possibly conspecific with Globigerinelloides prairiehillensis have been cited eight times from rocks equivalent in age to the Pierre Shale in Canada and the western interior. Of these citations, five are in lists only; two (Loetterle, 1937, pl. 7, figs. 4a, b; Nauss, 1947, pl. 48, figs. 9a, b) do not seem to belong in this species; and one (North and Caldwell, 1964, pl. 4, figs. 8a, b) may be Globigerinelloides prairiehillensis.

Although the specimen illustrated by Nauss (1947, pl. 48, figs. 9a, b) does not seem to belong in Globigerinelloides prairiehillensis, specimens from the Lea Park Formation probably conspecific with Nauss' concept of Globigerinella aspera are considered by John Wall (written commun., 1968) to be indistinguishable from Red Bird specimens here placed in Globigerinelloides prairiehillensis.

\section{Genus GLOMOSPIRA Rzehak, 1888}

\section{Glomospira charoides (Jones and Parker)}

Plate 2, figure 4

Trochammina squamata var. charoides Jones and Parker, 1860, Geol. Soc. London Quart. Jour., v. 16, p. 304.

Glomospira charoides (Jones and Parker). White, 1928, Jour. Paleontology, v. 2, no. 3, p. 187, pl. 27, fig. 7.

Mello, 1969, U.S. Geol. Survey Prof. Paper 611, p. 42, pl. 4, figs. $4 a, b$.

Glomospira corona Cushman and Jarvis. Tappan, 1962, U.S. Geol. Survey Prof. Paper 236-C, p. 130, pl. 29, figs. 13-16.

North and Caldwell, 1964, Saskatchewan Research Council, Geology Div. Rept. 5, p. 12, pl. 1, figs. 6a, b.

Remarks.-Five specimens, none of which is perfectly preserved, are placed in this species. The test is composed of a proloculus and a tubular, undivided second chamber. The visible part of the test consists of a bell-shaped structure formed by spirals of the second chamber, the interior of the bell being filled, possibly by earlier coils and the proloculus. The aperture is the open end of the tube at the lower margin of the bell. The wall is noncalcareous and apparently composed entirely of cement. The Red Bird specimens compare very well to specimens assigned to this species from the Pierre Shale of north-central South Dakota by Mello (1969, p. 42), except that the Red Bird specimens are somewhat more translucent.

This species has apparently been variously reported as Glomospira charoides, $G$. charoides subsp. corona or var. corona, and $G$. corona. In the original description of variety corona, Cushman and Jarvis (1928, p. 89) state, "Variety differing from the typical in having the irregularly coiled later portion in a sort of irregular crown at the end of the test instead of coiling about the whole test as in the typical form." Tappan (1962, p. 130, pl. 29, figs. 13-16) elevates variety corona to specific rank, but she does not illustrate the irregularly coiled stage nor give any additional morphologic criteria to discriminate $G$. corona from the "typical" $G$. charoides. Admittedly, the original description of Trochammina squamata var. charoides is very inadequate, and it may be that the North American species is to be distinguished from the initially described European species, but this should not be done without adequate documentation. For the lack of such documentation, $G$. corona is suppressed as a distinct species. North and Caldwell $(1964$, p. 12) report that some of the specimens that they cite as G. corona have a distinctive tubular cap and others do not. This would suggest that variety corona as originally defined is an advanced growth stage of $G$. charoides rather than a separate species or subspecies.

Occurrence and range.-It has not been possible to examine the specimens cited in faunal lists as Glomospira charoides var. corona by Applin (1933), Searight (1938), and Wickenden (1945), but these citations are included in this discussion. Applin's (1933, p. 219) citation is from the Pierre Shale of South Dakota; Searight's (1938, p. 135) is from his (1937) Sully Member of the Pierre Shale of middle Campanian age in South Dakota and northern Nebraska; and Wickenden's $(1945$, p. 50) is from the Riding Mountain Formation of middle Campanian age in Manitoba and Saskatchewan. Mello (1969, p. 42) cited $G$. charoides from the late Campanian and possibly early Maestrichtian parts of the Pierre Shale in South Dakota, and North and Caldwell (1964, p. 12) cited $G$. corona from the late Santonian or early Campanian part of the Lea Park Formation in south-central Saskatchewan. Tappan's (1962, p. 130) citation of $G$. corona is from beds of Albian age in northern Alaska. 
Genus GLOMOSPIRELLA Plummer, 1945

Glomospirella inconstans Mello, $n$. sp.

Plate 3, figures 1, 2

Ammodiscus cretaceus (Reuss). Mello, in Gill and Cobban, 1965, U.S. Geol. Survey Prof. Paper 392-A, p. A12, A13 [list].

Mello, 1969, U.S. Geol. Survey Prof. Paper 611, p. 41, pl. 4, fig. 3.

Description.-Test moderately biconcave to planar, composed of a central proloculus and undivided tubular second chamber, earliest part of second chamber generally irregularly coiled about the proloculus but quickly becomes planispiral, size of the irregularly coiled part variable and apparently absent in a few specimens; in the planispiral part each whorl overlaps from one-fourth to one-half the height of the preceding whorl, two to nine whorls composing the planispiral part. Second chamber increases regularly and gradually in size with growth, has occasional constrictions of probable diagenetic origin, collapsed in many specimens. Wall noncalcareous, smooth to slightly roughened, thin and translucent in most small specimens, becomes thicker, opaque, and white in most larger specimens; some smaller specimens are thick walled, and some larger specimens remain thin walled; composed predominantly of cement in which numerous grains barely discernible at $\times 200$ are embedded; translucent specimens appear to lack the grains. Spiral suture slightly depressed on undistorted specimens, more light absorbent than adjacent chamber walls and thus easily discernible. Aperture the open end of the second chamber.

Dimensions.-Average-sized specimens are approximately $0.25 \mathrm{~mm}$ in diameter. Thickness of the test measured parallel to the axis of coiling is usually $0.04 \mathrm{~mm}$ or less in flattened specimens but may be twice that in unflattened specimens of average size. The largest undistorted Red Bird specimen is $0.13 \mathrm{~mm}$ thick and $0.52 \mathrm{~mm}$ in maximum diameter. Specimens more than twice as large have been seen in other samples.

Remarks.-The irregularly coiled earliest part of the second chamber is the character on which these specimens are assigned to Glomospirella. Because this irregular coiling involves so little of the earliest and smallest part of the second chamber, it can only be observed in the best preserved smaller specimens. In most larger specimens the central part of the test is apparently covered by secondary wall growth, and the irregular coiling is obscured or completely covered. Observation of this irregular coiling on all the smaller, filled specimens and the regular size progression from smaller to larger specimens that is shown by the Red Bird specimens indicates that both small and large specimens belong in this species. A very few specimens that are otherwise the same as those showing the early irregular coiling are apparently planispiral throughout. The extremely small size of the irregularly coiled part might be easily overlooked, even if not obscured by shell overgrowth or preservation.

The presence of the irregularly coiled early part of the second chamber in the Red Bird specimens prompted a reexamination of specimens from the Pierre Shale of north-central South Dakota assigned to Ammodiscus cretaceus (Reuss) by Mello (1969, p. 41). Two of these South Dakota specimens clearly show the irregular early coiling, and in many other specimens there is strong indication of its existence. The scarcity of specimens positively having this feature is due to the scarcity in the South Dakota samples of small specimens having uncollapsed walls. Also, the irregularly coiled part is smaller and much more difficult to see in these specimens. Complete gradations in size from specimens almost as small as some of those at Red Bird to those considerably larger than any of the Red Bird specimens have been found in the South Dakota samples.

Specimens assigned to $A$. cretaceus from the Gregory Member of North Dakota (Mello, in Gill and Cobban, 1965, p. A12, A13) were reexamined and also clearly showed the early irregular coiling and other characteristics of $G$. inconstans $\mathrm{n}$. sp. It seems very likely that this species has routinely been identified as $A$. cretaceus, but a synonymy of references cannot be constructed at this time because $I$ have not yet had the opportunity to examine comparative specimens. Two small crushed paratypes of G. umbilicata (Cushman and Waters), the type species of Glomospirella, are very similar to $G$. inconstans, but most of the type specimens are irregularly coiled throughout, are much larger, and have much thicker chambers than do the Red Bird specimens.

There is some possibility that $G$. inconstans may be confused with Psamminopelta bowsheri Tappan, and especially with $P$. subcircularis Tappan, described from the middle Cretaceous of northern Alaska (Tappan, 1962 , p. 157, 158). In P. subcircularis, the plan of coiling is planispiral in the later part of the test, and the junctures where the semicircular chambers meet are difficult to see.

A very similar and perhaps ancestral species to $G$. inconstans is Ammodiscus kiowensis Loeblich and Tappan reported from the Kiowa Shale Member of the 
Purgatoire Formation of Kansas (Loeblich and Tappan, 1950 , p. 5, pl. 1, fig. 3). This species, which should also be placed in Glomospirella, appears to differ importantly from the $G$. inconstans n. sp. in retaining irregular coiling for more of its growth. The irregular coiling persists throughout in the holotype, which is at least twice the diameter of the irregularly coiled part of $G$. inconstans n. sp. Forms transitional between these two species should be looked for in middle Cretaceous deposits.

\section{Genus GYROIDINA d'Orbigny, 1826}

Gyroidina depressa (Alth)

Plate 3, figure 5

Rotalina depressa Alth, 1950, Haidinger's Naturw. Abh., v. 3, p. 266 , pl. 13, fig. 21 .

Gyroidina depressa (Alth). Cushman and Church, 1929, California Acad. Sci. Proc., 4th ser., v. 18, no. 16, p. 515, pl. 41, figs. 4-6.

Mello, 1969, U.S. Geol. Survey Prof. Paper 611, p. 85, pl. 10, figs. $2 a-c$.

Remarks.-About a dozen specimens were found which are referable to this species as described by Mello (1969, p. 85) from the Pierre Shale of South Dakota. The Red Bird specimens seem to differ only in usually having eight chambers, instead of nine to 11, in the final whorl, although some specimens have as many as 10. A discussion of the range of variation observed for this species, into which the Red Bird specimens fit, is given by Mello (1969, p. 85).

Gyroidina depressa has been reported a number of times from the Cretaceous interior seaway. I have refrained from synonymizing those references which appear in lists only and for which comparative material has not been seen, partly because I believe forms referred to this species may be more finely divisible. This point is discussed more fully under Gyroidina girardana.

Occurrence and range.-Gyroidina depressa has been reported from the Pierre Shale undifferentiated of South Dakota by Applin (1933, p. 219), from the late Campanian and early Maestrichtian part of the Pierre Shale of South Dakota by Mello $(1969$, p. 85), from the middle Campanian Sully Member of the Pierre Shale in South Dakota and northern Nebraska by Searight $(1938$, p. 135), from the middle Campanian "chalk zone" of the Pierre Shale in South Dakota by Loetterle $(1937$, p. 42), from the middle Campanian Gregory Member of the Pierre Shale of North Dakota by Mello (in Gill and Cobban, 1966, p. A12, A13), from the inferred middle Campanian Hilliard Shale of southwestern Wyoming by Gauger (in Jones, 1953, p. 80, pl. 9, figs. 21-26), and with question from the Upper Cretaceous of Manitoba and Saskatchewan by Wickenden (1945, p. 42).

\section{Gyroidina girardana (Reuss)}

Plate 3, figure 6

Rotalina girardana Reuss, 1851, Deutsche geol. Gesell. Zeitschr., v. 3, p. 73, pl. 5, fig. 34 .

Gyroidina girardana (Reuss). Cushman, 1931, Jour. Paleontology, v. 5, p. 311, pl. 36, figs. 1a-c.

Mello, 1969, U.S. Geol. Survey Prof. Paper 611, p. 88, pl. 10, figs. 3a-c.

Remarks.-A few specimens, characterized by the planoconvex test, seven to eight chambers in the final whorl, and marked increase in depth of the chambers on the umbilical side as added, are placed in Gryoidina girardana. Comparison of these specimens was made with specimens of this species from the Pierre Shale in north-central South Dakota, and a fuller discussion of morphology, range, and similar species was given in an earlier report (Mello, 1969, p. 88). None of the Red Bird specimens reaches the size of the largest South Dakota specimens, but in other respects agreement is good.

Morphotypes from the western interior, Canadian, and Alaskan beds that have been placed in Gyroidina girardana, G. depressa, G. nitida, G. globosa, G. globosa orbicella, and possibly in species of Gavelinella, by various authors may be part of a rapidly evolving lineage. Slight morphologic differences have been found among at least the first four species listed above from samples of the Montana Group and older rocks of the western interior that I have examined. These differences seem to be stratigraphically separable and hold promise for more accurate and reliable foraminiferal biostratigraphy than is now possible for these rocks in the absence of planktonic species.

Occurrence and range.-The only previous record of this species in rocks of the Montana Group and equivalents of the Cretaceous interior seaway north of the Gulf Coastal Plain was by Mello (1969, p. 88) from the late Campanian and possibly early Maestrichtian part of the Pierre Shale in South Dakota. Cushman $(1946$, p. 140, 141) reported it from beds of Austin, Taylor, and Navarro ages in the Gulf Coastal Plain.

\section{Gyrotidina sp. 1}

Plate 3, figure 4

Description.-Test low trochospiral, involute and moderately convex on umbilical side, partially evolute and slightly convex on spiral side, consisting of one to 
11/2 whorls, with a large proloculus and six to eight chambers per whorl, axial periphery rounded, equatorial periphery smooth to slightly lobulate, has a shallow, dimplelike umbilicus without extensions into it from the chambers. Chambers closely appressed, slightly inflated, increasing regularly and moderately in size as added. Sutures moderately oblique on spiral side, slightly convex forward, on umbilical side radial at the umbilicus, straight or slightly convex forward, apparently slightly to moderately limbate, especially near the umbilicus and spiral suture, spiral suture indistinct, apparently limbate. Wall granular in microstructure, frosted in appearance, slightly roughened, rather thick, apparently secondarily thickened, especially over the central area on the spiral side, rather finely perforate, nearly opaque when dry, yellowish white. Aperture a low-arched interiomarginal slit, bordered above by a slight thickening of the chamber wall, extending from about the equatorial periphery toward the umbilicus for about three-quarters of the length of the base of the apertural face; end toward the umbilical side gradually tapers, spiral side ends in a small reentrant of the septal face.

Dimensions.-This species attains a maximum diameter of $0.28 \mathrm{~mm}$ measured in the plane of coiling and a maximum thickness of $0.15 \mathrm{~mm}$ measured parallel to the axis of coiling.

Remarks.-The morphology of the specimens described above does not seem to coincide in all particulars with any previously described species. However, because of the limited number of specimens and because the relationships between and the variability within the species of Gyroidina so far reported from the Cretaceous interior seaway are badly in need of more precise definition, no new name is applied to these specimens here. The most characteristic features of the specimens are the rather broadly rounded axial periphery, low and smoothly convex sniral side, not very deeply convex umbilical side, curved and oblique spiral side sutures, and frosted appearance of the wall.

Genus HapLophragmoIdes Cushman, 1910

Haplophragmoides calcula Cushman and Waters

Plate 4, figure 7

Haplophragmoides calcula Cushman and Waters, 1927, Cushman Lab. Foram. Research Contr., v. 2, pt. 4, p. 83, fig. 5 .

Remarks.-A few specimens distributed at least from the Red Bird Silty Member to the upper unnamed shale member of the Pierre Shale at Red Bird compare favorably with the type specimens of Haplophragmoides calcula. The species, as described by Cushman and Waters $(1927$, p. 83$)$, is characterized by close coiling, strong compression, and a very coarsely arenaceous and roughly finished wall. The very rough wall texture makes internal structure indiscernible on most specimens, but several paratypes appear to have six or seven chambers in the final whorl, and the Red Bird specimens apparently have five to seven chambers. The most striking characteristics of this species are the extremely coarse grain size and rough wall texture. Angular translucent grains of quartz protrude strongly from the surface, and when the chambers are filled, these grains frequently appear dark and give the test a mottled appearance.

There does seem to be some gradation toward finer wall texture among some groups of Red Bird specimens, and $H$. calcula may be known by other names in less arenaceous environments. Cushman (1946, p. 20) raises the possibility that this species represents the young stages of Ammobaculites. However, there are no equally coarse-grained species of Ammobaculites in the Red Bird samples.

Occurrence and range.-Haplophragmoides calcula is reported from the inferred middle and late Campanian part of the Hilliard Shale in southwestern Wyoming by Gauger (in Jones, 1953, p. 53, pl. 4, figs. 7-9, 13). Cushman (1946, p. 20) reported it from beds of Austin, Taylor, and Navarro ages in the Gulf Coastal Plain.

Haplophragmoides excavata Cushman and Waters, emended

Haplophragmoides excavata Cushman and Waters, 1927, Cushman Lab. Foram. Research Contr., v. 2, pt. 4, p. 82, pl. 10, figs. 3a, b.

Haplophragmoides glabra Cushman and Waters, 1927, Cushman Lab. Foram. Research Contr., v. 2, pt. 4, p. 83, pl. 10 , figs. 6a, b.

Haplophragmoides kirki Wickenden, 1932, Royal Soc. Canada Trans., 3d ser., v. 26 , sec. 4 , p. 85 , pl. 1 , figs. $1 \mathrm{a}-\mathrm{c}$.

North and Caldwell, 1964, Saskatchewan Research Council, Geology Div. Rept. 5, p. 13, pl. 1, fig. 8.

? Peterson, in Jones, 1953, Utah Geol. and Mineralog. Survey Bull. 47, p. 31, pl. 1, figs. 5a, b.

Haplophragmoides bonanzaensis Stelck and Wall. Tappan, 1962, U.S. Geol. Survey Prof. Paper 236-C, p. 133, pl. 30, figs. 16, 18 [not figs. 17, 19].

Mello, 1969, U.S. Geol. Survey Prof. Paper 611, p. 43, pl. 4, figs. $6 a, b$.

Description.-Test planispiral, usually completely involute, but last three or four chambers of some larger specimens slightly evolute, best preserved specimens moderately robust, have slightly to moderately lobulate equatorial periphery and rather broadly rounded axial periphery, though in many specimens the axial periphery is narrowly rounded owing to inferred secondary compression. Considerable variation in these general characters of the test have been ob- 
served and are interpreted as being due to distortion of these tests during compaction. Umbilici shallow, narrow to moderately wide, present on most wellpreserved specimens. Final whorl consists of as few as $41 / 2$ and as many as 10 chambers, but most specimens have six to nine chambers; in undistorted specimens, chambers wedge shaped in side view, slightly inflated, increase regularly and gradually to fairly abruptly in size as added; in undistorted specimens, sutures straight, flush to slightly depressed, radial to slightly oblique, usually inconspicuous and often obscured by granularity of the wall, sometimes limbate. Wall varies from very thin in some small specimens to quite thick in coarser grained specimens, very variable in size of grains embedded in the wall, fine-grained specimens smoothly finished, with surface luster, coarse-grained specimens rough-textured, numerous specimens show a wide range of grain sizes; all discrete grains are quartz, have white cement, may be yellow or rust stained; wall almost always white but may be light or dark gray or brown when filled owing to the absorption and reflection of light by the material filling the test; walls of filled specimens contain a high percentage of seemingly dark colored grains which are really grains of clear quartz. Aperture a very low, equatorial, interiomarginal slit extending a short distance to either side of the periphery, commonly not preserved or poorly preserved.

Remarks.-A very large degree of variability is expressed by the specimens grouped together here into Haplophragmoides excavata emended. This grouping was done only after an exhaustive observational comparison of all specimens of Haplophragmoides from the Red Bird samples. The populations of specimens show considerable variation in grain size, degree of test compression, chamber shape and number, and degree of involution.

Such variation is probably typical of the genus and has, I suspect, resulted in overproduction of names, as it has in the case of $H$. excavata. It may be that the variations are a direct response to as yet undiscovered environmental controls, or perhans they are simply reflective of a genetic flexibility which might suggest that test architecture was of less than vital importance to the living animal. In any event, it seems better to group the variants, which I believe are really more or less extreme variations on the same mornhologic theme, under one name than to continue to focus on their differences in order to retain the established names. Five general morphologic end members, called formas, have been recognized and serve to qualify the morphology of specimens placed in them. These formas are considered to be interrelated elements of a single species and are not of themselves valid taxonomic entities. The comparisons on which discussions of these formas are based were made with type and comparative specimens in the Cushman and U.S. National Museum collections. Numerous other described Cretaceous species, principally from Canada, are not considered because of the lack of comparative specimens, though it seems likely that several of these may be synonymous with $H$. excavata as here emended.

\section{Haplophragmoides excavata undifferentiated}

Remarks.-Most of the Red Bird specimens have been placed in one of the five recognized formas but, principally because of poor preservation, a small group of specimens could only be given the more general species designation. The samples from which these specimens came are listed below.

Samples and relative abundances.-21-VR, 22-R, 24-S, 25-S ?, 26-VR ?, 27-S ?, 31-R, 32-RR, 37-VR.

Occurrence and range.-Of the four references that follow, two cite Haplophragmoides excavata in lists, and two describe and illustrate $H$. excavata too inadequately for confident placement in any of the formas recognized here. The specimens are cited here under H. excavata undifferentiated in order to record their existence. $H$. excavata was reported with question from the middle Campanian part of the Lea Park Shale of Alberta (Nauss, 1947, p. 331), from the middle Campanian part of the Pierre Shale of South Dakota and northern Nebraska (Searight, 1938, p. 135), and from the late Santonian, Campanian, and early Maestrichtian of northeastern Utah and southwestern Wyoming (Peterson, in Jones, 1953, p. 30, pl. 1, figs. 3, 4; Gauger, in Jones, 1953, p. 54, pl. 4, fig. 10).

Haplophragmoides excavata Cushman and Waters forma kirki Plate 4, figure 2

Discussion.-The description and figures given by Wickenden $(1932$, p. 85 , pl. 1, figs. 19-c) for Haplophragmoides kirki Wickenden, the only paratype in the Cushman collection (No. 19000), show that this species is small and involute, has the last whorl composed of four or five chambers, and has a rounded periphery, robust shape, and a low interiomarginal apertural slit.

Many specimens from the Red Bird samples fit the type description and compare favorably to the paratype, and many are filled like the paratype. These small robust specimens have four, or more commonly five, chambers, involute coiling, a broad perinhery, and a low equatorial aperture grading into other forms in 
the samples. There is a gradation in terms of mode of preservation from filled, perfectly preserved, and darkcolored specimens through incompletely filled and partially compressed specimens to white, flattened specimens which are otherwise similar to the filled specimens. Another gradation, indicated by numerous intermediate specimens, is toward greater size and increasing number of chambers in the final whorl. In some samples this dual trend leads to specimens that have robust test shape and fine-grained walls like the smaller specimens but have six or seven chambers in the final whorl; such specimens are included in forma alpha. In other samples, the average grain size increases as test size increases, and these specimens are included in forma beta. Another trend is toward specimens that are slightly compressed, have six to eight chambers, and generally fine-grained walls; such specimens are included in forma glabra. Finally, specimens that increase in chamber number as they increase in size and that are considerably compressed are considered to be transitional to forma excavata. Specimens of forma kirki attain a maximum diameter of $0.26 \mathrm{~mm}$ and a thickness, measured parallel to the axis of coiling in undistorted specimens, of $0.15 \mathrm{~mm}$. Most specimens, however, are less than three-quarters of this size.

Samples and relative abundances.-35-VR, 44-S, 45VR, 46-R, 47-VR, 48-VR，49-VR，51-VR，61-VR, 64-S, 69-S, 71-RR.

Occurrence and range.-North and Caldwell (1964, p. 13, pl. 1, fig. 8) reported Haplophragmoides kirki, bearing six chambers in the final whorl, from the late Santonian and early Campanian part of the Lea Park Shale in south-central Saskatchewan. Forma kirki was also reported, as $H$. bonanzaensis, by Mello (1969, p. 43) and at least in part by Tappan (1962, p. 133, pl. 30, fig. 16, 18, figured hypotypes P6005 and P6004 and unfigured hypotypes P6012 and P6006). Mello's report is from the late Campanian and early Maestrichtian part of the Pierre Shale in South Dakota, and Tappan's is from the Turonian Seabee Formation and from the middle Campanian part of the Schrader Bluff Formation in northern Alaska.

Other reports of $H$. kirki are from the inferred early Campanian part of the Frontier Formation in northeastern Utah (Peterson, in Jones, 1953, p. 31, pl. 1, figs. $6 \mathrm{a}, \mathrm{b})$, from the early Campanian part of the Lea Park Shale of Alberta (Nauss, 1947, p. 331), and from the middle to late Campanian and early Maestrichtian Bearpaw Formation of Alberta (Loranger and Gleddie, 1953, p. 166, fig. 3 and pl. 3, figs. 6, 7, 49, 50; Wickenden, 1932, p. 85, pl. 1, figs. 1a-c).
Haplophragmoides excavata Cushman and Waters forma alpha

Plate 4, figure 1

Discussion.-The group of specimens placed here is characterized by smoothly finished, fine-grained wall texture, intermediate to rather large size, involute planispiral coiling, six to eight chambers in the final whorl, commonly visible sutures, and robust test shape. Most specimens, and especially the larger specimens, are at least partially distorted. Distortion is more commonly found in forma alpha than in forma beta, presumably because the smaller grains are not so tightly interlocked and thus do not form so rigid a test wall in forma alpha. This group is artificial in the sense that all stages of transition between it and forma kirki and forma beta are to be found. The transition to forma beta involves an increase in average grain size and the resultant coarsening of the wall texture. Forma alpha and forma beta do not occur equally in samples where they occur together. Such samples contain many more of one forma or the other, but in some of these samples the transition between the two formas in clearly indicated.

Forma alpha attains a maximum diameter, measured in the plane of coiling, of about $0.91 \mathrm{~mm}$ and a maximum thickness, measured parallel to the axis of coiling on slightly distorted specimens, of about 0.37 $\mathrm{mm}$. Forma alpha is similar to the holotype and paratypes of Haplophragmoides flagleri Cushman and Hedberg var. trinitatensis Cushman and Renz, from the Upper Cretaceous of Trinidad, in test size and shape and chamber number and shape. However, the wall texture of var. trinitatensis, is smoother and more fine grained than that of forma alpha, and the umbilici, though not deep, are still somewhat deeper than those on most specimens of forma alpha.

Samples and relative abundances.-20-S?, 37-R, 38-VR, 45-VR, 46-RR, 49-R, 50-S, 51-VR 55-VR, 56-RR, 57-RR, 58-RR, 59-RR, 61-VR, 62-R, 63-S, 64-S, 65-R, 66-R, 67-S, 69-S, 70-VR, 71-RR, 72-R, 73-RR, 74-S.

Haplophragmoides excavata Cushman and Waters forma beta Plate 4, figure 4

Discussion.-The characteristics of forma beta are moderate to rather coarse grain size and resultant rough wall texture, rather robust test shape in undistorted specimens, and six to 10 chambers in the final whorl, though nearly all snecimens have seven to nine. Many specimens assigned here show a wide range in grain size, coarser grains frequently being most abundant in the umbilical regions. In specimens in which the 
chambers are not inflated, the number of chambers is difficult to determine because the coarse wall texture obscures the sutures. Specimens considered to be transitional to forma alpha show all stages in grain-size increase and coarsening wall texture from the smoothtextured and fine-grained forma alpha to typical forma beta. Relationship between forma beta and forma excavata also seems to be clearly indicated. Forma excavata is a secondarily, probably diagenetically compressed form having chamber walls depressed below the sutures, and specimens showing various stages in this compression from robust undistorted forma beta to forma excavata are available.

Large specimens of forma beta reach a maximum diameter, measured in the plane of coiling, of 0.90 $\mathrm{mm}$ and a maximum thickness, measured parallel to the axis of coiling on undistorted specimens, of 0.40 mm.

Samples and relative abundances.-19-X, 20-S?, 23-RR ?, 29-VR, 30-VR, 33-R, 34-RR, 36-VR, 37-RR, 38-VR, 39-R, 40-R, 41-RR, 42-VR, 43-R, 44-VR, 45-VR, 46-RR, 47-R, 48-VR, 49-R, 50-VR, 51-R, 52-R，53-R，55-R，57-RR，58-RR，59-RR，60-VR, 61-R, 62-R, 63-S, 64-X?, 65-VR?, 66-R, 67-S, 68-S, 69-VR, 70-R, 71-VR?, 72-RR, 73-RR, 74-S, 75-X.

\section{Haplophragmoides excavata Cushman and Waters forma excavata}

\section{Plate 4, figure 3}

Discussion.-The holotype of Haplophragmoides excavata Cushman and Waters is apparently lost, and comparison of the Red Bird specimens was made with a plesiotype (Cushman colln. 26811) illustrated by Cushman (1946, pl. 2, fig. 15) and with other specimens of this species in the Cushman collection. The Red Bird specimens placed in what is here recognized as forma excavata are composed of seven to 10 chambers in the final whorl, the last part of which is slightly evolute on some larger specimens, have moderately to coarsely granular walls, and are characterized by their lenticular shape and the presence of at least a few depressed or excavated chambers between elevated sutures. All degrees of compression between the rather robust specimens assigned to forma beta and the lenticular and excavated specimens assigned to forma excavata are to be found in the Red Bird faunas. Forma excavata is considered to consist of secondarily compressed specimens of forma beta, at least some of the chambers of which have been depressed more deeply than the presumably more rigid intercameral walls. The scarcity of specimens of fine-grained forma excavata related to forma alpha may be due to a less rigid structure of the intercameral walls in these finegrained specimens. Compressed specimens of forma alpha do exist but, at least in the specimens available, the chambers are only very rarely excavated. The specimens from the Cushman collection which were used for comparison also show varying degrees of compression and excavation and are comparable to the Red Bird specimens in this variability, although the walls of most of the Red Bird specimens contain coarser grains than the walls of most of the comparative specimens.

Large specimens of forma excavata attain a maximum diameter, measured in the plane of coiling, of about $0.75 \mathrm{~mm}$. Maximum thickness parallel to the axis of coiling is in part a function of degree of secondary compression but is about $0.25 \mathrm{~mm}$ for large specimens.

Samples and relative abundances.-29-VR, 30-VR, 34-RR, 36-VR, 39-R, 44-VR, 47-R, 49-R, 50-VR, 51-VR，52-R，53-R，54-RR，55-R，56-RK，57-RR, 58-R, 59-R，60-VR，61-VR，65-R，69-VR，70-R, 71-R, 72-R, 73-R.

Occurrence and range.-The reported occurrences of Haplophragmoides excavata in rocks of the Montana Group and age equivalents in the Cretaceous interior seaway are given under the discussion of $H$. excavata undifferentiated.

Haplophragmoides excavata Cushman and Waters forma glabra

Plate 4, figure 5

Discussion.-Fifteen specimens from the Red Bird samples are closely comparable with the holotype of Haplophragmoides glabra Cushman and Waters and are here placed in forma glabra. They are moderately compressed and have an abruptly rounded axial periphery, six to eight chambers in the final whorl, smoothly finished walls containing fine- to medium-sized quartz grains, wedge-shaped chambers, and sutures which are radial or slightly oblique to the umbilicus and straight or slightly convex toward the apertural end. In terms of grain size, surface texture, and number of chambers, most of these specimens appear to be moderately compressed specimens of forma alpha, though a few, of coarser grain size, are more like forma beta. Several of the specimens placed in forma glabra have one or a few chambers slightly depressed, including the illustrated specimen (pl. 4, fig. 5), as in forma excavata. On the basis of these similarities, $H$. glabra is considered to be synomymous with $H$. excavata emended and is here designated as forma glabra. It is worth noting that a number of the specimens of $H$. glabra in the Cushman collection show transitions to forma alpha, forma beta, and esnecially to forma excavata, better than do the few Red Bird specimens. Of nine samples from which 
Cushman (1946, p. 20) reported $H$. glabra, six also contain $H$. excavata (Cushman, 1946, p. 21).

Well-developed and relatively large specimens of forma glabra attain a maximum diameter of $0.37 \mathrm{~mm}$ and a maximum thickness of $0.18 \mathrm{~mm}$.

Samples and relative abundances.-37-VR, 45-VR, 64-X, 66-VR, 69-S.

Occurrence and range.-Haplophragmoides glabra has been listed with question from the inferred middle Campanian part of the Bearpaw Formation of Alberta (Loranger and Gleddie, 1953, p. 166). Cushman (1946, p. 20) reported it from beds of Navarro age in the Gulf Coastal Plain.

Haplophragmoides sp. 1

Plate 4, figure 8

Remarks.-Two specimens (one is poorly preserved and the other is well preserved except for a crushed final chamber) are placed under this designation. Distinguishing characteristics are the small, much compressed, almost completely evolute, planispiral or extremely low trochospiral test composed of two whorls, the inner of which contains nine chambers and the outer 12 chambers; the noncalcareous, apparently very finely arenaceous, smoothly finished walls; the gradual increase in size of the slightly inflated, closely appressed chambers; the well-defined, slightly depressed, slightly oblique, and slightly curved sutures; the subacute axial periphery; and the slightly lobulate equatorial periphery. The aperture could not be observed in either of the specimens. No previously described species of Haplophragmoides or Trochammina from the western interior seems to be similar to $H$. sp. 1 .

\section{Haplophragmoides sp. 2}

Plate 4, figure 9

Description.-Test generally planispiral, partially evolute to involute on both sides, some specimens slightly asymmetrical with respect to degree of involution; some specimens apparently slightly trochospirally or slightly streptospirally coiled at least in part; moderately deep and moderately wide umbilici give the test a biconcave shape even on asymmetrical specimens; equatorial periphery slightly lobulate, axial periphery rather broadly rounded. Distortion of specimens not so common for this species as for specimens of other species of Haplophragmoides in the Red Bird samples. Chambers slightly inflated, in side view wedge-shaped in involute specimens, more keystone shaped in evolute specimens, seven to 10 in final whorl, $81 / 2^{-10}$ in medium- and large-sized specimens, increasing regularly and slowly in size as added. Sutures slightly depressed, limbate, appearing as thin gray bands when specimens are moistened, straight or very slightly convex forward, radial or very slightly oblique. Wall rather thick, composed of moderately fine to moderately coarse particles deeply embedded in resinous, clear to white, glistening cement, which gives the walls a relatively smooth appearance; coarser grained walls contain numerous smaller grains, and finer grained walls contain scattered larger grains; grain size not a function of specimen size; nearly all grains are quartz. Apertural face low, aperture a low to moderately arched interiomarginal opening equatorial in position in most specimens and extending toward but not to the umbilici, extending more toward the umbilical side in specimens in which the last whorl is asymmetrical; filled with darker material in all specimens.

Dimensicns.-For the largest specimens, maximum diameter in the plane of coiling is about $0.70 \mathrm{~mm}$, and maximum thickness parallel to the axis of coiling is about $0.36 \mathrm{~mm}$.

Remarks.-The Red Bird specimens are distinguished by the moderately deep umbilici, which may be partially filled, the number of chambers in the final whorl, the common development of a partially evolute final whorl, and, for most specimens, the wall of glistening resinous cement.

The specimens here placed in Haplophragmoides sp. 2 seem quite distinctive in their morphology, but the species has apparently not been previously described. It seems to be similar to the holotype and type description of $H$. fraseri Wickenden from the Upper Cretaceous Bearpaw Formation of Canada (Wickenden, 1932, p. 86, pl. 1, fig. 2a, b) in all respects except wall texture. $H$. fraseri is reported to have a wall composed of few, rather fine, angular grains and much cement. The color is described as white to yellowish. A single paratype of this species (Cushman, 1946, pl. 3, fig. 1) was available for comparison, but it differs markedly from the type description and from illustrations of the holotype, being low trochospiral and completely involute and having seven chambers in the final whorl. In the type description, the species is described as being planispiral and partially involute, and having nine or 10 chambers in the last whorl. Despite the similarities between $H$. fraseri as described and $H$. sp. 2, the marked difference in wall composition is considered to justify their separation.

The specimens assigned to $H$. sp. 2 are similar to some specimens assigned to $H$. excavata forma beta in size, test shape, and appearance of the wall, but it 
seems possible to distinguish the specimens at hand consistently on the basis of the greater inflation of chambers and more evolute mode of coiling of $H . \mathrm{sp} .2$.

Haplophragmoides? species indeterminate

Remarks.-A large number of specimens recognizable as probably belonging in the genus Haplophragmoides but too fragmentary or distorted to be identified to the species level are included under this designation. Some specimens placed here probably belong in Trochammina.

\section{Genus HETEROHELIX Ehrenberg, 1843}

Heterohelix globulosa (Ehrenberg)

Plate 5, figure 8

Textularia globulosa Ehrenberg, 1834, Kgl. preussische Akad, Wiss. Berlin Abh., p. 135, pl. 4, figs. 2, 4, 5, 7, 8.

Guembelina globulosa (Ehrenberg). Egger, 1899, Kgl. bayerische Akad. Wiss. Math.-naturw. Abt. Abh., Kl. 2, v. 21, pt. 1, p. 32 , pl. 14, fig. 43 .

Heterohelix globulosa (Ehrenberg). Montanaro-Gallitelli, 1957, U.S. Natl. Mus. Bull. 215, p. 138, pl. 31, figs. 12-15.

Pessagno, 1967, Palaeontographica Americana, v. 5, no. 37, p. 260, pl. 87, figs. 5-9, 11-13.

Mello, 1969, U.S. Geol. Survey Prof. Paper 611, p. 70, pl. 8, figs. $5 a, b$.

Remarks.-About 30 well-preserved specimens of this species were recovered from the Red Bird samples. Internal molds tentatively assigned to this species were found in several other samples. Slight variability was found among these specimens in globularity of the chambers and thickness of the test, but they are all considered to belong in Heterohelix globulosa. Very faint vertical striations are present on the chamber walls of a few specimens.

The small group of Red Bird specimens placed tentatively in $H$. ultimatumida (White) may represent an extreme in variation of $H$. globulosa, but the lack of specimens showing intermediate morphology warrants their separation at this time.

Occurrence and range.-Heterohelix globulosa is a very widely reported species from Cretaceous rocks, and undoubtedly many references to it are in error in terms of modern classifications. This species, as redefined and recognized by Pessagno (1967, p. 260), ranges throughout strata of Campanian and Maestrichtian ages. Records of $H$. globulosa from the Cretaceous interior seaway cited below refer only to occurrences in beds of Campanian and Maestrichtian age.

Heterohelix globulosa has been reported, in recent years, from the late Campanian and early Maestrich- tian part of the Pierre.Shale in South Dakota (Mello, 1969, p. 70), from the Gregory Member of the Pierre Shale of middle Campanian age in North Dakota (Mello, in Gill and Cobban, 1965, p. A12, A13), and from the early Campanian part of the Lea Park Formation in south-central Saskatchewan (North and Caldwell, 1964, p. 21, pl. 3, figs. 11a, b). As Guembelina globulosa the species has been reported from the Pierre Shale of South Dakota (Applin, 1933, p. 219), from the Sharon Springs Member of the Pierre Shale of early Campanian age in Colorado (LeRoy and Schieltz, 1958 , p. 2453 , fig. 1), from the early Campanian part of the Pierre Shale in South Dakota (Loetterle, 1937, p. 34, pl. 5, fig. 3), from the late Campanian part of the Bearpaw Formation in Alberta (Loranger and Gleddie, 1953, p. 166, fig. 3), and from the Boyne Member of the Vermilion River Formation, partly of early Campanian age, in Manitoba and Saskatchewan (Wickenden, 1945, p. 42).

\section{Heterohelix pulchra (Brotzen)}

Plate 5, figure 10

Guembelina pulchra Brotzen, 1936, Sveriges geol. undersökning Årsb., Ser. C, no. 396, v. 30, p. 121, pl. 9, figs. 3a, b.

Guembelina pseudotessera Cushman, 1938, Cushman Lab. Foram. Research Contr., v. 14, pt. 1, p. 14, pl. 2, figs. 19-21.

Heterohelix pulchra (Brotzen). Montanaro-Gallitelli, 1957, U.S. Natl. Mus. Bull. 215, p. 137, pl. 31, fig. 20.

Mello, 1969, U.S. Geol. Survey Prof. Paper 611, p. 71, pl. 8, figs. $4 a, b$.

Remarks.-Two specimens are assigned to this species. They are distinguished from Heterohelix globulosa (Ehrenberg), with which they occur, in having lower, more elongate chambers resulting in a more compressed test and in having a lower arched aperture than is typical for $H$. globulosa. The last one or two chambers in the Red Bird specimens show a tendency to overlap slightly the preceding chamber on the opposite side of the test. Faint striations are visible on most of the chambers in both specimens.

Occurrence and range.-Heterohelix pulchra has been reported from the Gregory Member of the Pierre Shale of middle Campanian age in North Dakota (Mello, in Gill and Cobban, 1965, p. A12, A13) and from the late Campanian and early Maestrichtian part of the Pierre Shale in South Dakota (Mello, 1969, p. 71). According to Pessagno (1967, p. 262), this species occurs in beds of Campanian and early Maestrichtian ages in the Gulf Coastal Plain. 


\section{Heterohelix cf. H. ultimatumida (White) \\ Plate 5, figure 9}

Guembelina ultimatumida White, 1929, Jour. Paleontology, v. 3, no. 1 , p. 39 , pl. 4 , figs. $13 \mathrm{a}$, b.

Heterohelix ultimatumida (White). Pessagno, 1962, Micropaleontology, v. 8 , no. 3, p. 356, pl. 1 , fig. 8 .

Remarks.-Six specimens from a single Red Bird sample are tentatively placed in this species. Chambers are few (no more than five pairs), globular, rather closely appressed, and abruptly enlarging so that the test is nearly as broad as it is high. The aperture is poorly preserved on all specimens but appears to be a low to moderate interiomarginal arch. All specimens are at least partly encrusted with a thin coat of calcite(?), but where the wall is exposed it is smooth and devoid of lineations. Assignment of these specimens to Heterohelix ultimatumida is tentative because of the poor preservation.

Occurrence and range.-According to Pessagno (1967, p. 265), Heterohelix ultimatumida occurs throughout the Campanian and in the early Maestrichtian age deposits of the Gulf Coastal Plain. It has not previously been reported from the Cretaceous interior seaway.

\section{Genus LAGENA Walker and Jacob, 1798 \\ Lagena apiculata (Reuss)}

Plate 5, figure 3

Oolina apiculata Reuss, 1850, Haidinger's Naturw. Abh., v. 4, p. 22, pl. 1, fig. 1 .

Lagena apiculata (Reuss). Reuss, 1862 (1863), Kgl. Akad. Wiss. Wien, Math.-Naturw. Kl. Sitzungsber., v. 46, p. 319 , pl. 1, figs. 4-8.

Mello, 1969, U.S. Geol. Survey Prof. Paper 611, p. 66, pl. 7, fig. 11.

Remarks.-Two specimens from a single sample are placed in this species. Each is single chambered, pyriform, and smooth walled, and each has a basal spine. The larger specimen has a thick, conical apertural neck composed of transparent shell material. The aperture is composed of several slits radiating from the apex and extending down the apertural neck for about half its height. A tube penetrates the axis of the apertural neck, but whether or not it continues into the chamber could not be determined because the chamber is filled. The apertural neck of the smaller specimen is broken. The Red Bird specimens compare very closely with the specimen of Lagena apiculata illustrated by Mello (1969, pl. 7, fig. 11).

Occurrence and range.-Lagena apiculata has been reported from the middle and early Campanian part of the Matanuska Formation in southern Alaska
(Bergquist, 1961, p. 2004, table 1) and from the late Campanian and possibly early Maestrichtian part of the Pierre Shale in South Dakota (Mello, 1969, p. 66).

\section{Genus LAGENammina Rhumbler, 1911}

Lagenammina difflugiformis (H. B. Brady)

Plate 4, figure 10

Reophax diffugiformis H. B. Brady, 1877, Quart. Jour. Micros. Sci., new ser., v. 19, p. 51, pl. 4, figs. 3a, b.

Proteonina difflugiformis (H. B. Brady). Rhumbler, 1903, Archiv. Protistenkunde, v. 3, p. 245, text figs. $80 \mathrm{a}$, b.

Description.-Test a single globular to flask-shaped chamber, often distorted in preservation, has a neck attaining a length as great as that of the chamber. Wall composed of large, generally angular, quartz grains set in a white to light-brown cement which also contains scattered fine grains, surface very rough; most grains are coarse but there is variation in grain size within individual specimens and between specimens. Aperture the open end of the apertural neck.

Dimensions.-Average-sized specimens of this species are about $0.41 \mathrm{~mm}$ in greatest length and $0.25 \mathrm{~mm}$ in greatest breadth perpendicular to the axis of elongation. The ratio of length to breadth is usually between 1.5:1 and 2.0:1 for complete specimens.

Remarks.-According to Loeblich, Tappan, and others (1964, p. C216), the type species of the genus Proteonina, into which this frequently reported species has most commonly been placed, has been shown to belong in the genus Reophax. The genus Lagenammina, characterized by a coarsely arenaceous wall, flasklike shape, and long apertural neck, seems to accommodate the Red Bird specimens very well. $L$. diffugiformis, originally described from the Holocene, is either very long ranging or the morphologic type has evolved several times. Specimens from the Holocene and Miocene in the U.S. National Museum collections are very similar to the Cretaceous specimens and seem to differ only in having a somewhat smaller average grain size.

Proteonina alexamderi Loeblich and Tappan, originally described from the Kiowa Shale Member of the Purgatoire Formation of Kansas (Loeblich and Tappan, 1950 , p. 5, pl. 1, figs. 1, 2), is very similar to the Red Bird specimens here assigned to $L$. diffugiformis, but the Red Bird specimens are coarser in average grain size and typically have a better defined apertural neck.

Occurrence and range.-L Lagenammina diffugiformis has been reported only once previously, under the generic name Proteonina, from rocks of Campanian or Maestrichtian ages in the Cretaceous interior seaway. 
FORAMINIFERA AT RED BIRD, WYOMING

The forms illustrated in the report (Gauger, in Jones, 1953, p. 52, pl. 4 , figs. 1-4) from the inferred late Campanian and early Maestrichtian part of southwestern Wyoming have a less well defined apertural neck than is typical for the Red Bird specimens.

\section{Genus IENTICULINA Lamarck, 1804}

Lenticulina muensteri (Roemer)

Plate 5, figure 1

Robulina muensteri Roemer, 1839, Versteinerungen norddeutschen Oolithengebirges, Nachtrag., p. 48 , pl. 22, fig. 29 .

Cristellaria muensteri (Roemer). Reuss, 1862 (1863), Kgl, Akad. Wiss. Wien, Math.-Naturwiss. Kl., Sitzungsber., v. 46 , pt. 1, p. 77 , pl. 9, figs. 3,4 .

Robulus muensteri (Roemer). Cushman, 1932, Jour. Paleontology, v. 6, p. 334, pl. 50, figs. 2 a, b.

Lenticulina muensteri (Roemer). ten Dam, 1948, Jour. Paleontology, v. 22, no. 2, p. 178 .

Remarks.-A single specimen is placed in Lenticulina muensteri. It is distinguished by its acute, thickened periphery, small but prominent umbos, nine chambers in the exposed whorl, and moderately convex forward sutures which become raised and limbate toward the umbos.

The genus Robulus, to which this species has most frequently been ascribed, is regarded as a synonym of Lenticulina by Loeblich, Tappan, and others (1964, p. C520). Because this revision eliminates separation of two forms on the basis of an inconstant feature (length of medial apertural slit), it is accepted here, and this species is placed in Lenticulina.

Occurrence and range.-This species has been reported, under the generic name Robulus, from the inferred middle Campanian part of the Hilliard Shale in southwestern Wyoming (Gauger, in Jones, 1953, p. 66, pl. 7, figs. 1, 2), with question from the early and middle Campanian part of the Matanuska Formation in southern Alaska (Bergquist, 1961, p. 2004), and from the late Campanian and early Maestrichtian part of the Pierre Shale in South Dakota (Mello, 1969, p. 53, pl. 5, figs. $6 a, b)$.

\section{Lenticulina cf. I. rotulata Lamarck}

Lenticulina rotulata Lamarck, 1804, Annals Mus., v. 5, p. 188; 1806, v. 8, pl. 62, fig. 110 .

Remarks.-A small group of specimens, which are varied in the degree of umbonation, curvature of the sutures, number of chambers, and acuteness of the periphery but which seem to be within the limits of variation for this species as illustrated by Cushman (1946, pl. 18, fig. 19 ; pl. 19, figs. 1-7), are placed with question in Lenticulina rotulata Lamarck. This species, and others from the American Cretaceous which are referred to Lenticulina, Robulus, and Planularia, are in need of thorough restudy and redefinition.

Occurrence and range.-Lenticulina rotulata has been reported from the inferred middle Campanian part of the Hilliard Shale in southwestern Wyoming (Gauger, in Jones, 1953, p. 67, pl. 7, figs. 3-5).

\section{Genus MARGINULINA d'Orbigny, 1826 \\ Marginulina of. $\mathbf{M}$. texasensis Cushman \\ Plate 5, figure 2}

Marginulina texana Cushman, 1937, Cushman Lab. Foram. Research Contr., v. 13 , pt. 4 , p. 95 , pl. 14, figs. 1-4. Homonym of $M$. texana Garrett and Ellis, 1937.

Marginulina texasensis Cushman, 1938, Cushman Lab. Foram. Research Contr., v. 14, p. 95.

Remarks.-A single complete specimen is tentatively assigned to this species. It is composed of a proloculus and four chambers which increase markedly in size as added. The first two chambers extend back nearly to the proloculus and form a partial coil, but the later chambers are uniserially arranged and extend toward the proloculus on the ventral side. The dorsal margin is moderately convex and becomes very convex near the base. The ventral margin is sinusoidal; the upper and ventral surfaces of the final chamber form the convex part of the curve, and the remainder of the ventral margin forms the concave part. The radial aperture is at the apex of the test on the dorsal margin. In top view the test is subrounded in outline.

This specimen differs from typical Marginulina texasensis in having more vertically inclined chambers, though inclination approximating that of the Red Bird specimen is shown by some plesiotypes and comparative specimens of this species in the Cushman collection.

Occurrence and range.-Marginulina texasensis has been reported from the inferred middle Campanian part of the Hilliard Shale of southwestern Wyoming (Gauger, in Jones, 1953, p. 69, pl. 8, fig. 2). It occurs in deposits of Taylor and Navarro ages in the Gulf Coastal Plain (Cushman, 1946, p. 61, pl. 21, figs. 21$29,38,40)$.

\section{Genus NEOBULIMINA Cushman and Wickenden, 1928}

Neobulimina canadensis Cushman and Wickenden-var. alpha

Plate 6, figure 1

Neobulimina canadensis Cushman and Wickenden, 1928, Cushman Lab. Foram. Research Contr., v. 4, p. 13, pl. 1, figs. 1, 2.

Nauss, 1947, Jour. Paleontology, v. 21, no. 4, p. 340, pl. 48, figs. 5a, b.

Tappan, 1962, U.S. Geol. Survey Prof. Paper 236-C, p. 185, pl. 48, figs. 18, 20-23, 27 [not figs. 19, 24-26]. 
Neobulimina canadensis Cushman and Wickenden var. alpha, Mello, 1969, U.S. Geol. Survey Prof. Paper 611, p. 78, pl. 9, figs. 5a-c.

Description.-Test initially triserial, upper onequarter to one-half of larger specimens biserial, transition from triserial to biserial arrangement rather abrupt. Chambers subglobular, in lower one-quarter to two-thirds of triserial part closely appressed, arranged in three discrete and slightly twisted tiers, in upper onethird to one-half of triserial part less closely appressed, in a more bulimine arrangement, and increase more abruptly in size as added, one to three pairs of inflated, moderately appressed, slightly offset pairs of chambers composing the biserial part. Sutures not limbate, slightly depressed between closely appressed chambers of triserial part, becoming progressively more deeply incised as appression of chambers decreases. Wall smooth throughout, has numerous moderate-sized perforations, radial in microstructure. Aperture in the triserial part a vertical or nearly vertical, tightly arched opening, one side of which is more elevated than the other and the base of which is formed by the top of the penultimate chamber; in the biserial part, the aperture is a less tightly arched opening having one side higher than the other and the base formed by the top of the penultimate chamber. No toothplate visible externally in available specimens but present as an internal connection between apertures.

Dimensions.-A verage specimens are about $0.23 \mathrm{~mm}$ long and $0.12 \mathrm{~mm}$ in greatest width (usually in the biserial part). For available specimens, maximum overall length is $0.32 \mathrm{~mm}$, maximum width is $0.16 \mathrm{~mm}$, and maximum length of triserial part is $0.26 \mathrm{~mm}$.

Remarks.-Neobulimina canadensis var. alpha was introduced by Mello (1969, p. 78) as a taxonomic means of separating specimens of the type described from similar but stratigraphically higher specimens, called $N$. canadensis var. beta, from the Pierre Shale of north-central South Dakota. Varieties alpha and beta are both present in the Red Bird samples, and, except for one possible mutual occurrence, they are not found in the same samples. Var. beta is first found at a higher stratigraphic level than the first occurrence of var. alpha, but the range of var. beta is completely contained within that of var. alpha.

Occurrence and range.-Neobulimina canadensis var. alpha was originally described from the late Campanian part of the Pierre Shale in north-central South Dakota (Mello, 1969, p. 78). Other figured specimens that seem referrable to var. alpha are included in Nauss (1947, pl. 48, figs. 5a, b) from the Lea Park Shale of late Santonian and early Campanian ages in Alberta and in Tappan (1962, pl. 48, figs. 18, 20-23, 27) from throughout the Schrader Bluff Formation of Coniacian, Santonian, and Campanian ages in northern Alaska. Other occurrences of $N$. canadensis $\mathrm{s}$. 1 . from beds of Campanian age were recorded by Bergquist (1966) and Mello (in Gill and Cobban, 1965, p. A12, A13).

\section{Neobulimina canadensis Cushman and Wickenden var. beta}

Neobulimina canadensis Cushman and Wickenden, 1928, Cushman Lab. Foram. Research Contr., v. 4, p. 13, pl. 1, figs. $1,2$.

Tappan, 1951, Cushman Lab. Foram. Research Contr., v. 2, no. 1 , p. 5 , pl. 1 , figs. 21 , b.

Tappan, 1962, U.S. Geol. Survey Prof. Paper 236-C, p. 185, pl. 48, figs. 19, 24-26 [not figs. 18, 20-23, 27].

Ncobulimina canadensis Cushman and Wickenden var. beta Mello, 1969, U.S. Geol. Survey Prof. Paper 611, p. 79, pl. 9 , figs. $4 \mathrm{a}-\mathrm{c}$.

Remarks.-A small number of specimens, all of which are poorly preserved, can be given this designation on the basis of comparisons made with the specimens placed in var. beta by Mello $(1969$, p. 71$)$, where a description and illustrations of well-preserved specimens are to be found. Briefly, var. beta is characterized by a much reduced triserial stage and a long twisted biserial stage. The separation of Neobulimina canadensis into two varieties is continued here pending the study of specimens representing more of the geographic and stratigraphic distribution of this species.

Occurrence and range.-Var. beta has previously been recorded from the late Campanian(?) and early Maestrichtian part of the Pierre Shale in north-central South Dakota (Mello, 1969, p. 79).

\section{Neobulimina navarroana (Cushman)?}

Virgulina navarroana Cushman, 1983, Cushman Lab. Foram. Research Contr., v. 9, p. 63, pl. 7, figs. 9, 10.

Neobulimina navarroana (Cushman). Mello, 1969, U.S. Geol. Survey Prof. Paper 611, p. 80, pl. 9, figs. 3a-c.

Neobulimina sp., Wall, 1960, Research Council Alberta Bull. 6, p. 31, pl. 5, figs. 15-22.

Remarks.-Eight specimens, all preserved as internal molds coated with limonite(?), are placed in this genus and species with question. The early part, in those specimens preserving it, is apparently composed of a small number of chambers in a bulimine arrangement. The later and much larger part of these specimens consists of as many as four pairs of chambers in a twisted biserial arrangement. The chambers in the biserial part are generally higher than wide and increase gradually in size as added. In side view the test is elongate and rather slender, and the early bulimine part tapers to a blunt point. In top view the test is oval.

The Red Bird specimens closely resemble the type 
specimens of Neobulimina navarroana in those characters that are preserved, but the absence of wellpreserved apertures, features of the wall, and details of early chamber arrangement leave the identification open to question. John Wall (written commun., 1968) has pointed out the similarity of the Red Bird specimens to specimens described and figured by him (Wall, 1960, p. 31, pl. 5, figs. 15-22) as Neobulimina sp. from the Puskwaskau Shale of ConiacianSantonian age in Alberta, Canada.

Occurrence and range.-Neobulimina navarroana has been reported from beds of early Maestrichtian age in north-central South Dakota (Mello, 1969, p. 80). It occurs in deposits of Navarro age in the Gulf Coastal Plain (Cushman, 1946, p. 127).

\section{Neobulimina spinosa Cushman and Parker}

Plate 6, figure 2

Neobulimina spinosa Cushman and Parker, 1936, Cushman Lab. Foram. Research Contr., v. 12, p. 9, pl. 2, figs. 11a, b.

Description.-Test consists of an early part in which nine to 12 chambers are arranged in a twisted triserial to bulimine fashion, followed by a biserial stage consisting of one to two pairs of chambers, the second pair, when present, being offset from the plane of the first pair, greatest width of the test at about the base of the final chamber. Chambers in triserial or bulimine part globular, rather closely appressed, increase regularly and moderately abruptly to very abruptly in size as added, chambers in biserial part teardrop shaped, increasing regularly and rather slowly in size as added. Sutures slightly to moderately depressed in triserial or bulimine part, moderately depressed in biserial part. Wall radial in microstructure, on best preserved specimens transparent, has rather widely scattered and fairly coarse perforations, in a few specimens has one or a few very tiny spines near the bases of chambers in the triserial or bulimine parts, most specimens completely devoid of spines. Aperture in the biserial part a small, oval- to loopshaped opening within a slightly protrudent and compressed structure at or near the apex of the final chamber, paralleled by a shallow, rather narrow trough which also lies within the protrudent structure but which could not be seen to open into the chamber; dissection of the final chamber revealed a ridge mirroring the surficial trough; on one specimen of three dissected there appears to be a very thin somewhat sinuous toothplate extending from the ridge to the trough of the penultimate chamber. The aperture on the triserial or bulimine chambers was not observed because all specimens found had progressed to the biserial stage.

Dimensions.-Average specimens are about $0.23 \mathrm{~mm}$ long and about $0.13 \mathrm{~mm}$ in maximum width. Large specimens reach a length of $0.29 \mathrm{~mm}$ and a maximum width of $0.16 \mathrm{~mm}$.

Remarks.-The Red Bird specimens differ from the type specimens of Neobulimina spinosa only in generally lacking spines. This difference is not thought to be important enough to consider the Red Bird specimens as a separate species or as a subspecies, especially in view of the fact that one of the paratypes also lacks spines. None of the types was dissected to determine whether the internal structures are present, although externally the apertures are the same as those in the Red Bird specimens.

Occurrence and range.-Neobulimina spinosa has not been reported previously from deposits of Campanian or Maestrichtian age in the Cretaceous interior seaway. I have observed it, however, in samples from the Crow Creek Member of the Pierre Shale in southern South Dakota. Cushman (1946, p. 126) reported it from beds of Navarro and Taylor ages in the Gulf Coastal Plain.

\section{Genus NODOSARIA Lamarck, 1812}

\section{Nodosaria obscura Reuss}

Plate 7, figure 10

Nodosaria obscura Reuss, 1845, Versteinerungen böhmischen Kreideformation, pt. 1, p. 26, pl. 13, figs. 7-9.

Remarks.-Three complete specimens, two of which are small and composed of three and four chambers, respectively, are assigned to this species. The largest specimen consists of seven closely appressed chambers, the first four of which increase rather abruptly in width but not height as added and the last three of which increase rather abruptly in height but little in width as added. The initial end in all three specimens is pointed, and the walls are ornamented by as many as eight fairly thick, elevated costae which coalesce near the initial end and which extend uninterrupted across sutures. At the apertural end these costae join a low terminal ring of shell material which encloses the simple subrounded aperture. Several topotypes of Nodosaria obscura are very closely similar to the large Red Bird specimen, and the remaining topotypes differ only in having a slightly protrudent apertural neck.

Occurrence and range.-Nodosaria obscura has not been reported previously from beds of Campanian or Maestrichtian age of the Cretaceous interior seaway. It occurs in beds of Austin, Taylor, and Navarro ages 
in the Gulf Coastal Plain (Cushman, 1946, p. 73, pl. 26 , figs. 15,16$)$.

\section{Genus NONIONELLA Cushman, 1926}

Nonionella cf. N. taylorensis Hofker

Nonionella cretacea Cushman, 1931 [not Operculina cretacea Reuss, 1862], Tennessee Div. Geology Bull. 41, p. 42, pl. 7, fig. 2.

Nonionella taylorensis Hofker, 1955, Naturhist. Maandblad, Jahrg. 44, no. 9-10, p. 99.

Description.-Test considerably compressed, very low trochospiral, involute on umbilical side, has a shallow, dimplelike umbilicus, slightly evolute on spiral side; equatorial periphery smooth, axial periphery abruptly rounded; final whorl composed of seven chambers. Chambers wedge shaped, slightly inflated, increase regularly and abruptly as added, first four in final whorl radially arranged to the axis of coiling, last three slightly oblique. Sutures straight or slightly convex forward, flush to slightly depressed. Wall smooth, unornamented, thin. Aperture an equatorial interiomarginal slit, presence of lateral extensions indeterminant, apertural face asymmetrical about the periphery, the larger lobe being on the umbilical side, without an extension into the umbilicus.

Remarks.-Originally described as Nonionella cretacea, the species name was changed to $N$. taylorensis to remove it from homonymy with Operculina cretacea Reuss, which is also a species of Nonionella. A sing'e pyrite-filled specimen was found. It is similar to the type specimens of $N$. taylorensis in degree of compression, size, rate of increase in chamber size, and degree of asymmetry of the final chamber. Nevertheless, assignment to $N$. taylorensis is questioned because of the lack of apertural details and because of the smaller number of chambers in the Red Bird specimen. Unfortunately, this specimen was lost during transfer for illustration.

Occurrence and range.-Nonionella taylorensis is present in all members of the Schrader Bluff Formation of Senonian age in northern Alaska (Tappan, 1962 , p. 190, pl. 50, figs. 10-12; Bergquist, 1966, pl. 14). Cushman (1946, p. 101, pl. 43, fig. 24) reported it from beds of Taylor and Navarro ages in the Gulf Coastal Plain.

\section{Genus OoLINA d'Orbigny, 1839}

Oolina obeliscata Mello

Plate 5, figure 4

Oolina obeliscata Mello, 1969, U.S. Geol. Survey Prof. Paper 611, p. 66, pl. 1, figs. 5a, b; pl. 7, figs. 12, 13.

Oolina n. sp. Mello, in Gill and Cobban, 1965, U.S. Geol. Survey Prof. Paper 392-A, p. A12, A13.
Remarks.-A single well-preserved specimen of this species, showing the slightly protrudent apertural neck, short basal spine (pyritized), internal tube, oval test shape, and smooth wall surface, was found. This species, of which the Red Bird specimen is typical, was first reported from the upper part of the Pierre Shale in north-central South Dakota by me in 1969, and a more complete description of it is to be found in that report.

Occurrence and range.-Oolina obeliscata has previously been reported, as $O$. n. sp, from the Gregory Member of the Pierre Shale of middle Campanian age in North Dakota (Mello, in Gill and Cobban, 1965, p. A12, A13). It was also reported from the late Campanian and early Maestrichtian part of the Pierre Shale in South Dakota (Mello, 1969, p. 66).

\section{PSEUDOBOLIVINA Weisner, 1931}

Pseudobolivina? sp. 1

Plate 4, figure 11

Remarks.-A small group of biserial specimens, moderately twisted and becoming loosely biserial to nearly uniserial in the later part, is given this designation. The walls are smooth and composed of fine quartz grains rather closely set in considerable cement except for one specimen which contains much larger quartz grains and which has a roughened surface. All but the coarser grained specimen are distorted, and most specimens are incomplete. The aperture is terminal or subterminal on the chambers of the loose biserial part and appears to be a round opening at the end of a slightly produced neck. No specimens preserving the aperture on the early less loosely biserial part were found.

The biserial to nearly uniserial twisted test and the apparent presence of a slightly produced apertural neck suggest that this species is to be placed in the genus Pseudobolivina. Because of the poor preservation, assignment to this genus is made with question. The specimens could not be placed in any previously described species known to me.

Dimensions.- The largest complete fine-grained specimen is $0.515 \mathrm{~mm}$ long and $0.154 \mathrm{~mm}$ in greatest width (slightly distorted). A partial specimen attains a maximum width of $0.195 \mathrm{~mm}$ (moderately distorted).

\section{Genus PSEUdOCLAVULINA Cushman, 1936}

Pseudoclavulina? meidamos Mello

Plate 5, figure 11

Pseudoclavulina? meidamos Mello, 1969, U.S. Geol. Survey Prof. Paper 611, p. 49, pl. 1, figs. 2a-c; pl. 5, figs. 1a-d. 
Remarks.-A group of 10 specimens from three samples is placed in this species. Diagnostic characters are the presence of an early trochoid part in which the chambers enlarge abruptly as added, followed by a uniserial part in which the chambers enlarge slowly as added, a straight or slightly arcuate slitlike terminal aperture, very fine grain size of the wall, and small test size. The Red Bird specimens differ from the type and comparative specimens of Pseudoclavulina? meidamos in being less well preserved, in having as many as six chambers in the uniserial part in contrast to a maximum of five in the types, and, for those specimens in samples 63 and 64 , in being noncalcareous. $P$.? meidamos was originally described as consisting largely, if not entirely, of agglutinated particles of $\mathrm{CaCO}_{3}$ held in a calcareous cement, but the noncalcareous Red Bird specimens, which resemble this species in all other observable features, do not react at all in dilute $\mathrm{HCl}$. In addition, the walls of these specimens are slightly rougher and contain slightly larger grains than do the types. All the Red Bird specimens are either incomplete or slightly to considerably distorted.

Occurrence and range.-Pseudoclavulina? meidamos has so far been reported only from the late Campanian and early Maestrichtian part of the Pierre Shale of South Dakota (Mello, 1969, p. 49).

\section{Genus REOPHAX Montfort, 1808}

Reophax sp. 1

Plate 5, figure 12

Reophax sp. A, Wall, 1960, Research Council Alberta Bull. 6, p. 14, pl. 3, fig. 10 .

Reophax sp. 1, Wall, 1967, Research Council Alberta Bull. 20, p. 44, pl. 5, figs. 3-5.

Description.-Test uniserial, robust, nearly always incomplete, distorted for all specimens, consists of one to four chambers, slightly tapers toward initial end; apertural end of final chamber slightly produced on some specimens, forming a short, broad neck. Chambers globular, loosely appressed, generally increase very slowly and regularly in size as added, but in some specimens one or two chambers above the proloculus are reduced in size; proloculus large, globular, has no basal spine. Sutures perpendicular to axis of elongation, deeply depressed. Wall rather thick, a mosaic of medium- and large-sized grains, most of which are quartz held in a relatively small amount of cement, collapsed or otherwise distorted on all specimens. Aperture not observed on any specimen; presumably a simple opening at the end of the short apertural neck.
Dimensions.-Available specimens have a maximum length of $1.23 \mathrm{~mm}$ and a maximum breadth, slightly crushed, of $0.57 \mathrm{~mm}$.

Remarks.-Specimens assigned to Reophax sp. 1 are distinguished from incomplete specimens of Ammobaculites coprolithiformis (Schwager) on the basis of the much smaller size and typically less depressed sutures of the latter. All chambers of specimens of $R$. sp. 1 are considerably larger than the largest chambers of $A$. coprolithiformis. $R$. sp. 1 bears a close resemblance in chamber shape and test form to $R$. constrictus (Reuss), but studied representatives of $R$. constrictus, including a topotype, seem to have a less rough wall containing more cement. This same observation was made by Wall $(1967 \mathrm{~b}, \mathrm{p} .44)$ in describing his $R$. sp. 1 . The importance of this feature as a distinguishing characteristic will have to await the finding of better preserved specimens. For the time being, Wall's informal nomenclature is retained.

Occurrence and range.-Wall (1960, p. 14; 1967a, p. 44) reported this species from the upper part of the Kaskapau Formation in northwestern Alberta and from the Wapiabi and Cardium Formations of the Rocky Mountain foothills of Alberta. These beds range in age from late Turonian to middle Santonian. Reophax constrictus (Reuss) has been reported from the Hilliard Shale of southwestern Wyoming (Gauger, in Jones, 1953, p. 51) of Campanian and early Maestrichtian ages. A few partial specimens assigned to Gaudryina bentonensis (Carman) by Mello (1969, p. 48) from the upper part of the Pierre Shale in South Dakota probably belong in this species.

\section{Genus RUGOGLOBIGERINA Bronnimann, 1952}

\section{Rugoglobigerina? sp.}

Remarks.-Two incomplete and poorly preserved specimens and one internal mold are assigned to this genus with question, on the basis of the globular chambers, the surfaces of which are slightly rugose, the low trochospiral mode of coiling that has two whorls each composed of five or six chambers, and the apparent presence of tegillae on two specimens.

\section{Genus SACCAMmINA M. Sars, 1869}

Saccammina complanata (Franke)

Plate 5, figures 6, 7

Pelosina complanata Franke, 1911, Kgl. preussische geol. Landesanst. Jahrb., v. 32, pt. 2, no. 1, p. 107, pl. 3, figs. 1a, b.

Saccammina sp. 1. Wall, 1967b, Research Council Alberta Bull. 20, p. 41, pl. 14, fig. 16. 
Description.-Test a single chamber; nearly all specimens flattened and circular or subcircular in outline, probably globular in life. Wall rather thick, noncalcareous, usually smooth and composed entirely or almost entirely of cement, in some specimens wall consists of very fine to moderately coarse quartz grains embedded in much cement and has a rougher surface. Aperture the open end of a stout tube; tube may be as much as one-quarter of the diameter of the test or little more than a thickened apertural margin.

Dimensions.-The largest specimen recovered is $0.817 \mathrm{~mm}$ in length along the apertural axis and 0.743 $\mathrm{mm}$ in breadth at right angles to this axis (the specimen is completely flattened). Most specimens are onequarter to one-half of this size.

Remarks.-Specimens that have walls containing numerous and obvious grains are few, and all intermediate stages between the coarsest and finest grained specimens are not represented. However, it seems unreasonable to split the group into several species on the basis of grain size when they are alike in test shape and apertural characters, so all are included here in Saccammina complanata.

Single-chambered globular specimens such as these could be placed in either Saccammina or Pelosina, according to Cushman (1948, p. 78, 81), depending upon whether the wall is composed of amorphous material (Pelosina) or is arenaceous (Saccammina). Loeblich, Tappan, and others (1964, p. C196, C200) indicate that Saccammina has a single opening, whereas Pelosina has two fine tubular extensions $180^{\circ}$ apart, either or both of which may function as apertures. Because the Red Bird specimens vary in wall texture but are constant in having only one opening, the distinctions between these genera as proposed by Loeblich, Tappan, and others (1964) are accepted, and the species complanata is placed in Saccammina.

The type figure of $S$. complanata (Franke, 1911, pl. 3, fig. 1a, b) shows only a single opening, and only one is mentioned in the type description (Franke, 1911, p. 107).

Occurrence and range.-Saccammina complanata has been reported, under the generic name Pelosina, from the Pierre Shale of South Dakota' (Applin, 1933, p. 219), from the late Santonian(?) and early to middle Campanian parts of the Matanuska Formation in south-central Alaska (Bergquist, 1961, p. 2004), and from the middle to late Campanian part of the Pierre Shale in southern South Dakota (Searight, 1938, p. 135). The specimen figured as Saccammina sp. 1 by Wall (1967b, p. 41, pl. 14, fig. 16) from the early Campanian part of the Lea Park Formation in Alberta is considered to belong in S. complanata.

\section{Genus SARACENaRIa Defrance, 1824}

Saracenaria triangularis (d'Orbigny)

Plate 5, figure 5

Cristellaria triangularis d’Orbigny, 1840, Soc. géol. France Mém., 1st ser., v. 4, p. 27, pl. 2, figs. 21, 22.

Saracenaria triangularis (d'Orbigny). Cushman and Church, 1929, California Acad. Sci. Proc., 4th sec., v. 18, no. 16, p. 505, pl. 37, figs. 13,14 .

Saracenaria sp.(?). North and Caldwell, 1964, Saskatchewan Research Council, Geology Div. Rept. 5, p. 18, pl. 3, figs. 2a-b, 5a-b.

Remarks.-A single well-preserved specimen is assigned to this well-known species. Its exposed whorl consists of six chambers; they enlarge abruptly as added, especially in breadth and thickness, so that the apertural face of the last chamber is broadly triangular in shape. Another less well preserved and smaller specimen from the same sample is assigned to this species with question.

Occurrence and range.-Saracenaria triangularis has been reported from the early and middle Campanian parts of the Matanuska Formation of south-central Alaska (Bergquist, 1961, p. 2004). Cushman (1946, p. 58) reported it from beds of Austin, Taylor, and Navarro ages in the Gulf Coastal Plain.

Saracenaria sp., described and illustrated by North and Caldwell (1964, p. 18, pl. 3, figs. 2a-b, 5a-b) and probably referrable to $S$. triangularis, occurs in the upper part of the Lea Park Formation of early Campanian age in southern Saskatchewan.

\section{Genus SILICOSIGMOILINA Cushman and Church, 1929}

\section{Silicosigmoilina futabaensis Asano \\ Plate 6, figure 5}

Silicosigmoilina futabaensis Asano, 1950, Pacific Sci., v. 4, no. 2 , p. 159 , pl. 1 , figs. 6,7 .

Mello, 1969, U.S. Geol. Survey Prof. Paper 611, p. 51, pl. 5, figs. 3a, $\mathrm{b}$.

Silicosigmoilina californica Cushman and Church. Applin, 1933, Jour. Paleontology, v. 7, no. 2, p. 219 [not Cushman and Church, 1929].

Description.-Test considerably compressed, generally oval in outline, but a few specimens nearly circular and many specimens fusiform in outline; early part indistinct, but chambers composing it obviously not in the plane of the later chambers; the addition of later chambers in planes about $180^{\circ}$ apart gives the test its compressed appearance; margins abruptly rounded to subacute. Chambers in early part 
indistinct, small, fairly numerous; in later planispiral or nearly planispiral part, very elongate, convex outward to sigmoidal, slightly overlapping; thin in small specimens, becoming increasingly broad and more overlapping in larger specimens. Wall noncalcareous, composed of numerous very fine grains in much cement, white, opaque, collapsed in many chambers. Sutures indistinct, visible only when moistened, if at all, flush with the surface. Aperture the open end of the final chamber, rounded or subrounded, has no discernible apertural tooth, closed or distorted by compression in most specimens.

Dimensions.-Available specimens attain a maximum length of $0.72 \mathrm{~mm}$ and a maximum breadth of $0.40 \mathrm{~mm}$. Maximum thickness of uncompressed chambers reaches $0.11 \mathrm{~mm}$. Most specimens are considerably narrower than the $7: 4$ length-to-breadth ratio would indicate.

Remarks.-The Red Bird specimens are identical with specimens from the Pierre Shale of north-central South Dakota assigned to this species by Mello (1969, p. 51), except that more of the Red Bird specimens are elongate or fusiform and fewer are subrounded in outline.

The type species of the genus Silicosigmoilina is S. californica Cushman and Church. In the original description, the early chambers are described as being planispiral or nearly so, that is, arranged in a single plane (Cushman and Church, 1929, p. 502), but one of their type figures (pl. 36, fig. 12), a cross-sectional view, shows no such early arrangement. Paratypes in the Cushman collection also show no planar early part (the holotype and figured paratypes are housed in the Museum of the California Academy of Sciences and were not examined in this study). The uncertainty about the nature of coiling in this genus raises serious question as to its true nature and possible validity. A decision on these points will have to be made based on all the type specimens, especially the holotype.

Of more distinct pertinence to this study, one of the smaller paratypes of S. californica (Cushman colln. 14496) has its later chambers arranged nearly in a plane, unlike the less planar, more overlapping sigmoidal arrangement in the other paratypes, and is very closely similar to the Red Bird specimens. This paratype may represent a stage of development immediately preceding the growth of larger more enveloping chambers which depart from the planar arrangement to form the more sigmoidal test shape. The Red Bird specimens may represent an earlier ontogenetic stage or a different level of evolutionary advancement than is shown by the paratypes of $S$. californica. Efforts to examine chamber arrangement in cross section of the Red Bird specimens were not successful owing to chamber fillings of the same color and consistency as the walls (possibly originally deposited by the living animal).

In summary, the status of the genus Silicosigmoilina is not clear because of the uncertainty raised here concerning the arrangement of its early chambers. Also, a paratype of S. californica, the type species of the genus, is very similar to the Red Bird specimens and suggests a close ontogenetic or evolutionary relationship. The Red Bird specimens are placed in S. futabaensis because the description and figures of this species seem to encompass them, at least in most respects. Both the genus Silicosigmoilina and its type species need redescription and more precise definition.

Occurrence and range.-Silicosigmoilina futabaensis has previously been described from the late Campanian part of the Pierre Shale in South Dakota (Mello, 1969, p. 51). Four authors have listed S. californica Cushman and Church from Cretaceous interior seaway deposits. Mello (1969) synonymized S. californica of Applin (1933, p. 219) from the Pierre Shale of South Dakota with S. futabaensis. In the absence of descriptions and illustrations, it is impossible to determine whether the following citations of $S$. californica might belong in $S$. futabaensis: Wickenden (1945, p. 50), from the Riding Mountain Formation of Manitoba and Saskatchewan; Bergquist (1961, p. 2004), from the Matanuska Formation of southcentral Alaska; Searight (1938, p. 135), from the Pierre Shale of southern South Dakota and northern Nebraska.

\section{Genus SPIRopLectammina Cushman, 1927}

Spiroplectammina sp. 1

Plate 6, figures 3,4 ; text figure 4

Description.-Test planispiral in earliest part; most of the test biserial, moderately compressed, tapers toward the planispiral part; rate of increase in width with growth variable from specimen to specimen, in most larger specimens rate of increase in width decreases in later part; lateral peripheries moderately to rather abruptly rounded, smooth to slightly lobulate; in many specimens left and right sides of the test meet in a low angle along the midline of the test, in other specimens the central area is smoothly arched instead of angled. Chambers in planispiral part very small, obscure, generally four to five visible, constituting the lower one-half of the planispiral part, the remainder generally being overlapped by the biserial 
part; chambers in the biserial part slightly or not at all inflated, overlapping about the upper one-third of the underlying chamber, narrowest at lateral peripheries, broadest at the midline, arranged at $45^{\circ}-80^{\circ}$, to the midline. Sutures flush to slightly depressed, straight or slightly convex upward. Wall moderately thick, rather smoothly finished, composed of numerous angular and rounded quartz grains set in a white to whitish-yellow cement; cement completely soluble in dilute $\mathrm{HCl}$ in some specimens, insoluble in others. Aperture a low-arched interiomarginal slit, forms about one-third of the base of the low apertural face, flanked by two slight extensions of the apertural face toward the penultimate chamber.

Dimensions.-Average sized specimens are about $0.40 \mathrm{~mm}$ long, $0.28 \mathrm{~mm}$ broad, and $0.18 \mathrm{~mm}$ thick. An idea of the range of variation in these dimensions can be obtained from the outline drawings in figure 4 .
Remarks.-This species varies in width of the test, angularity of the midline, angularity of the lateral peripheries, and nature of the wall cement. Treatment of about 40 specimens from five samples with acid showed that soluble- and insoluble-walled specimens sometimes occur in the same sample. Of about 25 tested specimens from three samples containing no calcareous Foraminifera other than internal molds, only one specimen had a soluble wall. In the other two samples, which do contain calcareous Foraminifera, both soluble and insoluble specimens were found. In all other respects, aside from wall solubility, the soluble- and insoluble-walled specimens are alike. Color of the wall is not correlated with its solubility.

The Red Bird specimens most closely approximate Spiroplectammina semicomplanata (Carsey) from the gulf coast Cretaceous deposits. However, the coarser grain size, greater chamber size, greater overall size,

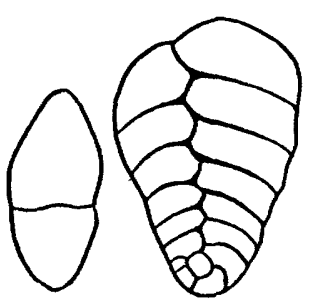

$a$

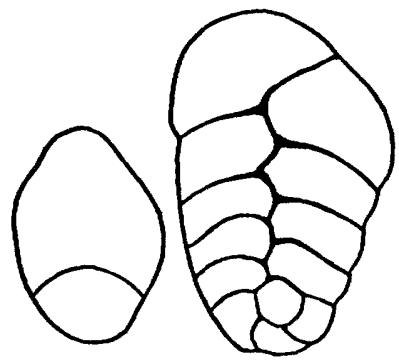

$b$

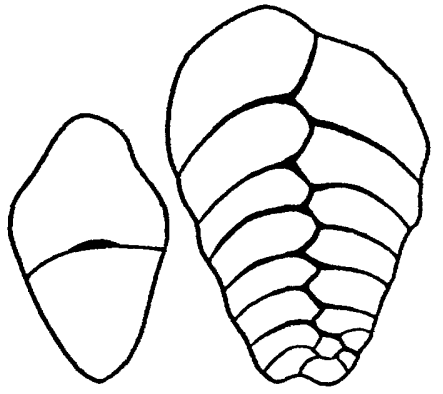

$c$

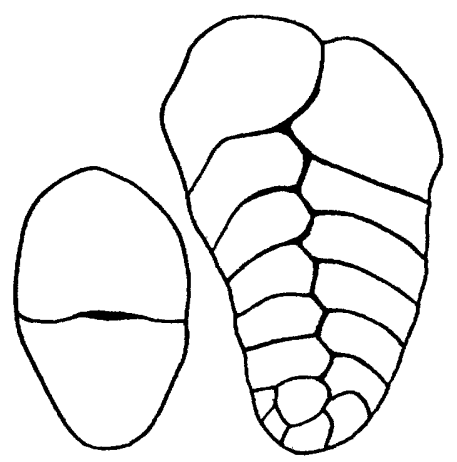

$d$

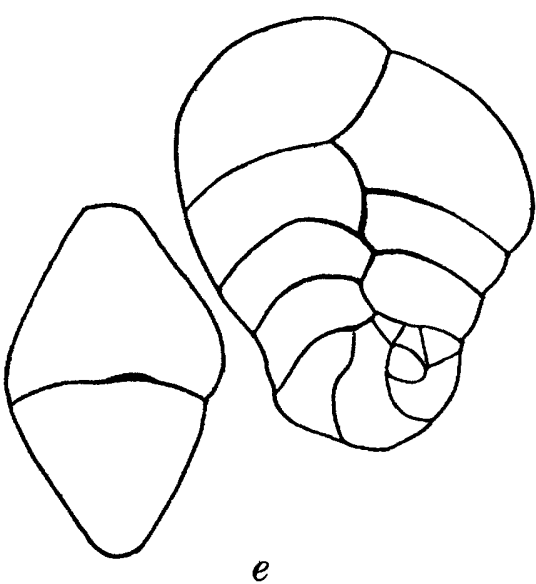

$e$
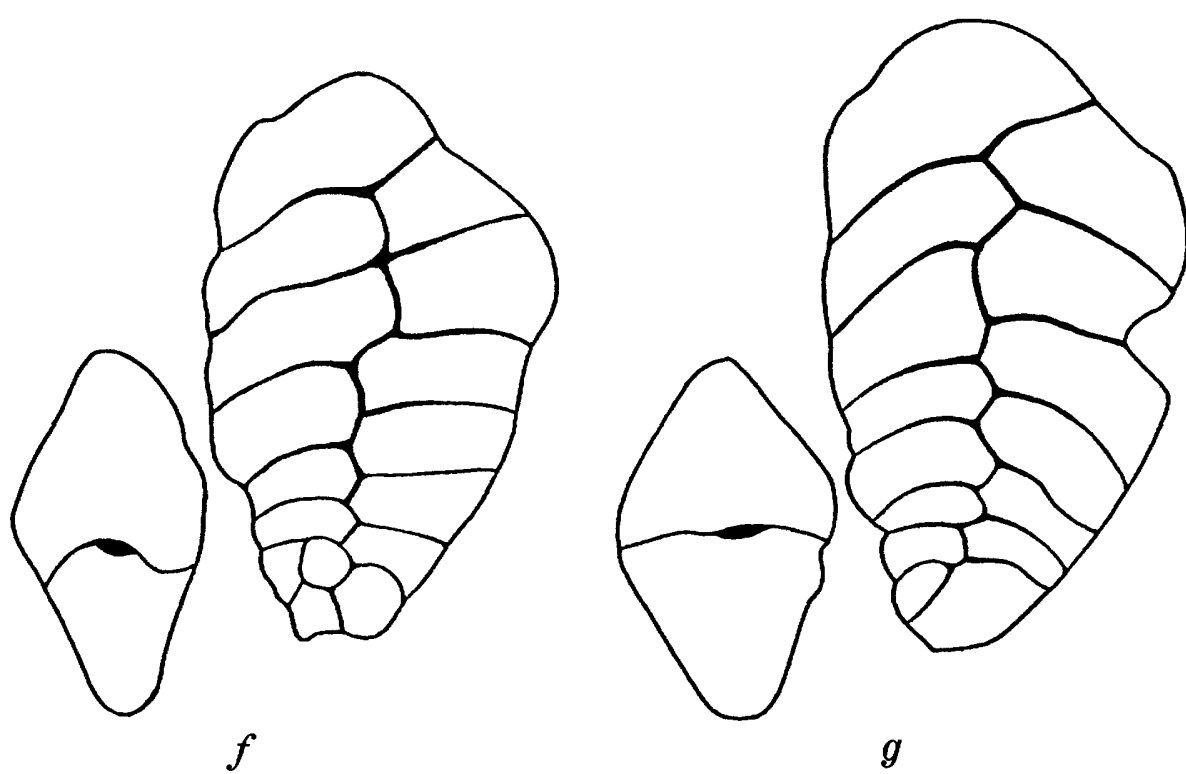

FigURE 4.-Outline drawings of Spiroplectammina sp. 1 and of a topotype of $S$. semicomplanata (Carsey). In each pair of drawings, the figure on the left is an apertural view and on the right, a side view. a, Topotype of Spiroplectammina semicomplanata (Carsey), $\times 106$, Cushman colln. 26965. $b-g$, Spiroplectammina sp. $1, \times 106: b$, USNM $68901 ; c$, USNM $68902 ; d$, USNM $68903 ; e$, USNM $68904 ; f$, USNM $68906 ; g$, USNM 68905 . 
less compressed test, and flush or only slightly elevated sutures of the Red Bird specimens distinguish them from topotypes of $S$. semicomplanata. Some of the Red Bird specimens approximate Spiroplectammina mordenensis Wickenden in having narrower tests and rather rounded lateral peripheries but differ in having lower chambers and much smaller planispiral parts. Comparison of the Red Bird specimens with type specimens and comparative specimens of numerous other Cretaceous species of Spiroplectammina, and examination of the Cretaceous literature, did not reveal a species to which the specimens could confidently be assigned. The Red Bird specimens seem to represent a previously undescribed species, but they are not given formal status as a new species here because, in my opinion, the Cretaceous representatives of Spiroplectammina have been oversplit, and a reexamination of variation in some of the established species may show that the Red Bird specimens belong in one of them.

\section{Genus STILOSTOMELLA Guppy, 1894}

Stilostomella sp. 1

Plate 7, figures 1-3

Description.-Test calcareous, rectilinear, consists of as many as nine chambers, tapers slowly toward the globular proloculus, has a short basal spine which is broken off on most specimens. Chambers moderately inflated, in early part wider than high and slightly to moderately overlapping, progressively becoming higher than wide and less overlapping so that the final few chambers overlap very slightly and are as high as wide or as much as $11 / 2$ times as high as wide. Sutures slightly depressed in early part, becoming progressively more depressed between succeeding chambers and rather deeply depressed between final few chambers of largest specimens, perpendicular to the axis of elongation. Wall thin, apparently a single layer, apparently nonperforate, granular in microstructure, surface roughened, has very faint, discontinuous vertical lineations, small spines sometimes present just above the boundary with the underlying chamber. Aperture situated at the top of a very short apertural neck, consists of a subrounded opening, bordered by a smooth, slightly thickened lip, some specimens having a relatively large indentation of the lip into the aperture, inner area of lip irregular to somewhat dentate.

Dimensions.-The only two unfigured specimens retaining the proloculus are, respectively, $0.44 \mathrm{~mm}$ long and $0.08 \mathrm{~mm}$ wide, and $0.23 \mathrm{~mm}$ long and $0.06 \mathrm{~mm}$ wide.
Remarks.-The granular wall structure and absence of perforations are interpreted to be due to recrystallization, and the eight Red Bird specimens upon which the description is based are placed in the genus Stilostomella. S. pseudoscripta (Cushman) and $S$. alexanderi (Cushman) are the only species of Stilostomella previously reported from Campanian or Maestrichtian rocks of the Cretaceous interior seaway. The Red Bird specimens are smaller, much less spinose, and much less constricted at the sutures than the types of $S$. alexanderi. Although the Red Bird specimens are similar in size to the types of S. pseudoscripta, they differ in lacking the distinctive pyriform chamber shape and numerous fine spines which are downward directed at the lower margins of the chambers. The Red Bird specimens have not been given a specific name, pending wider study of rocks from the Cretaceous interior seaway. As far as can be determined from the figures, the specimens illustrated by North and Caldwell (1964, pl. 4, figs. 2, 3) as Stilostomella pseudoscripta from the Lea Park Formation of southern Saskatchewan are closely similar to the Red Bird specimens in terms of chamber shape, occasional presence of scarce spines, and overall test shape. North and Caldwell's specimens are about $0.65 \mathrm{~mm}$ long and 0.12 mm wide.

\section{Genus TEXTULARIA Defrance, 1824}

Textularia sp. 1

Plate 7, figure 5

Textularia inflata Gauger?, [not Textularia inflata Ehrenberg, 1854, Mikrogeologie, pl. 30, fig. 12], in Jones, 1953, Utah Geol. and Mineralog. Survey Bull. 47, p. 60, pl. 6, figs. 12-14.

Description.-Test noncalcareous, biserial, elongate, tapers gradually from a very narrow, rounded initial end to the greatest breadth and width at the last pair of chambers; lateral peripheries slightly to moderately lobulate; outline in apertural view oval. Chambers inflated, subglobular, closely appressed, increase regularly in size as added, sutures slightly to moderately depressed, not limbate, generally at $90^{\circ}$ angles to the axis of elongation but occasionally slightly less than $90^{\circ}$. Wall almost always white, translucent except when chambers are filled, has very few silt or sand grains visible at $\times 200$, much silicious (?) cement; apparently originally somewhat flexible judging from the large proportion of flattened or distorted specimens, slightly roughened in texture on undeformed specimens. Aperture destroyed or covered on all but one specimen on which it is a small, low-arched open- 
ing at the base of the low apertural face of the final chamber.

Dimensions.-Average specimens are about $0.25 \mathrm{~mm}$ long, $0.08 \mathrm{~mm}$ in maximum breadth, and $0.05 \mathrm{~mm}$ in maximum thickness. The largest specimen (crushed) is $0.44 \mathrm{~mm}$ long.

Remarks.-The Pierre specimens are distinguished by the inflated, subglobular chambers (when uncrushed) and by the typically white and translucent wall. The brief original description and poor type figures of Textularia inflata Gauger make the assignment of the Pierre specimens to this species doubtful. Points of similarity are the elongate and narrow test and the presence of inflated apparently subglobular chambers.

Although Textularia inflata Gauger is a homonym, no new name is proposed here because I have not seen the type specimens. On the basis of the inadequate description and figures, the Red Bird specimens seem to be identical with Gauger's specimens from Wyoming. An apparently similar but also poorly illustrated species is Textularia gravenori Stelck and Wall from the Cenomanian of Alberta (Stelck and Wall, 1955, p. 55 , pl. 2, fig. 36 ).

The Red Bird specimens resemble Textularia topagorukensis Tappan (Tappan, 1957, p. 205, pl. 66, figs. 8,9 ) in chamber shape, test shape, wall texture, and suture angle, but $T$. topagorukensis has larger and fewer chambers, is larger in size and more robust, has more silt grains embedded in the walls, and is distinct from the Red Bird species.

Occurrence and range.-Textularia inflata Gauger was reported from the inferred middle Campanian part of the Hilliard Shale of southwest Wyoming (Gauger, in Jones, 1953, p. 60, pl. 6, figs. 12-14).

\section{Genus TROCHAMMnNA Parker and Jones, 1859}

Trochammina diagonis (Carsey)

Plate 6, figure 7

Haplophragmoides diagonis Carsey, 1926, Texas Univ. Bull. 2612 , p. 22 , pl. 3 , fig. 1 .

Trochammina diagonis (Carsey). Cushman and Waters, 1927, Cushman Lab. Foram. Research Contr., v. 2, pt. 4, p. 84 , pl. 10, figs. 7a, c.

?. Gauger, in Jones, 1953, Utah Geol, and Mineralog. Survey Bull. 47, p. 64, pl. 6, fig. 20.

Tappan, 1962, U.S. Geol. Survey Prof. Paper 236-C, p. 153, pl. 38, figs. 1-4.

North and Caldwell, 1964, Saskatchewan Research Council, Geology Div. Rept. 5, p. 16, pl. 2, figs. 7a-c.

Description.--Test low trochospiral, possibly streptospiral in earliest part, most specimens of $11 / 2$ to two whorls, usually completely involute on spiral side but occasionally slightly evolute, test becomes moderately evolute in the few very large specimens, umbilical side moderately convex but has a central umbilicus which is narrow and deep on larger undistorted specimens, shallower and proportionately broader on smaller specimens, spiral side generally slightly to moderately convex but planar or slightly concave on some specimens, equatorial periphery slightly to moderately lobulate, axial periphery narrowly rounded in smaller specimens, gradually becomes more broadly rounded as size increases, abrupt in some specimens inferred to be distorted. Chambers inflated, six to eight in final whorl of most specimens, but as many as 11 in some of the largest specimens, enlarge regularly and fairly abruptly in size as added; in either spiral- or umbilical-side view, most chambers shaped like blunt, bulging wedges, but some are sharply wedge shaped and others show little taper at all from periphery to inner margin. Sutures slightly to moderately depressed, straight in side views, radial on umbilical side, radial to moderately oblique on spiral side. Wall thin and finely arenaceous in smallest specimens, becomes thicker and increases in average grain size as specimen size increases; however, even the largest specimens are not exceptionally coarse grained; all but the largest grains are deeply embedded in cement, and thus the wall has a rather smooth surface texture; nearly all grains are quartz. Aperture observed on only two large specimens, in which it is a low interiomarginal opening extending from about one-half the height of the first chamber of the final whorl into the umbilicus and thence beneath the umbilical margin of the final chamber.

Dimensions.-A few specimens attain a maximum diameter of $1.0 \mathrm{~mm}$ (crushed), but average-size specimens are approximately $0.35 \mathrm{~mm}$ in greatest diameter and $0.27 \mathrm{~mm}$ in least diameter measured in the plane of coiling through the center of the test (crushed specimens).

Remarks.-Comparison has been made with a topotype of Trochammina diagonis (Cushman colln. 40314). There is a remarkable similarity in wall texture, color, and grain size between this specimen and the plesiotype illustrated here, as well as many of the other larger Pierre specimens. The topotype is slightly larger than the plesiotype and more distorted, but, for specimens that lack sharply distinctive morphologic features, agreement is very good. Smaller specimens assigned to this species are not so closely comparable with the topotype in that they have much smaller chambers, thinner walls, and finer grain size. These specimens are included in $T$. diagonis, sometimes with 
question, on the basis of their trochospirality, frequent association with larger specimens assignable to the species, and because in a few samples suites of specimens transitional from the smaller to the larger specimens indicate that they are to be placed together.

Virtually every Red Bird specimen assigned to this species is distorted, as are most of the plesiotypes and comparative specimens in the Cushman collection. Consequently the assignment of specimens to this species is more subjective than for most species.

Occurrence and range.-Trochammina diagonis (Carsey) has been reported from the inferred middle and late Campanian parts of the Hilliard Shale of southwest Wyoming (Gauger, in Jones, 1953, p. 64, pl. 6, fig. 20), from the lower part of the Lea Park Formation of late Santonian age in south-central Saskatchewan (North and Caldwell, 1964, p. 16, pl. 2, figs. 7a-c), and from the upper two-thirds of the Schrader Bluff Formation of late Santonian and Campanian ages in northern Alaska (Tappan, 1962, p. 153, pl. 38, figs. 1-4; Bergquist, 1966, pl. 14).

\section{Trochammina globosa Bolin \\ Plate 6, figure 8}

Trochammina globosa Bolin, 1956, Jour. Paleontology, v. 30 , no. 2 , p. 289 , pl. 38 , figs. 8,9 ; text figs. 5 , 7 .

Mello, 1969, U.S. Geol. Survey Prof. Paper 611, p. 52, pl. 5 , figs. 5a-c.

Description.-Test trochospiral, involute on umbilical side, evolute on spiral side, spiral side low convex, umbilical side concave, has a broad, shallow umbilicus, available specimens of two whorls or less, final whorl consists of five to seven chambers, axial periphery rather abruptly rounded, equatorial outline roughly ovate, equatorial periphery slightly lobulate. Chambers increase regularly and rather abruptly in size as added; subequant, often somewhat arched in spiralside view; in umbilical-side view wedge shaped because of the extension into the umbilicus, often somewhat arched, slightly to moderately compressed parallel to the axis of coiling. Sutures in spiral and umbilical side views straight to moderately convex toward the apertural end, sometimes radial but more commonly slightly to moderately oblique to the axis of coiling, indistinct because of coarse grain size. Wall rough textured, thick, composed of a large proportion of relatively coarse grains, nearly all of which are quartz, set in a flat-white to yellowish-white cement; very few small grains are present except proportionately more on smaller specimens, especially on the umbilical sides.

Dimensions.-Average size specimens are approximately $0.36 \mathrm{~mm}$ in maximum diameter and $0.29 \mathrm{~mm}$ in minimum diameter, measured across the spiral side through the center of the test, and are approximately $0.18 \mathrm{~mm}$ in height, measured parallel to the spiral axis.

Remarks.-Characteristic features of this species are the generally wide, shallow umbilicus, low-spired convexo-concave shape, the ovate outline resulting from the fairly abrupt chamber enlargement coupled with the evolute nature of the spiral side, the compressed and frequently arcuate chamber shape, and the usual abundance of coarse grains in the wall.

'The Red Bird specimens are more compressed than is indicated in the type description and figures of Trochammina globosa Bolin, and if this compression is a primary character not related to preservational distortion, it might warrant their separation as a new species. The Red Bird specimens are closely similar to specimens of $T$. globosa reported from the Pierre Shale of South Dakota (Mello, 1969, p. 52).

Occurrence and range.-Trochammina globosa has been reported only twice previously-from the early Maestrichtian part of the Pierre Shale in South Dakota (Mello, 1969, p. 52), and from well cores in Minnesota, very tentatively dated as Cenomanian (Bolin, 1956, p. 289).

\section{Trochammina ribstonensis Wickenden}

Plate 6, figure 6

Trochammina ribstonensis Wickenden, 1932, Royal Soc. Canada Trans., 3d ser., v. 26, sec. 4, p. 90 , pl. 1 , figs $12 \mathrm{a}-\mathrm{c}$.

Nauss, 1947, Jour. Paleontology, v. 21, no. 4, p. 340, pl. 49, figs. $6 a-c$.

Tappan, 1962 [part], U.S. Geol. Survey Prof. Paper 236-C, p. 154-155, pl. 39, figs. 16, 17 [not figs. 15a-c].

Wall, 1967b, Research Council Alberta Bull. 20, p. 67, pl. 10, figs. 20-25.

Description.-Test low trochospiral, most specimens having $11 / 2-21 / 2$ whorls and six to $81 / 2$ chambers per whorl, equatorial periphery lobulate, axial periphery rounded, has a broad, moderately deep umbilicus. Chambers moderately inflated, rather closely appressed, increasing gradually and regularly in size as added. Sutures slightly depressed between early chambers, moderately depressed between last four or five chambers, slightly to moderately oblique on spiral side, slightly oblique to radial on umbilical side, convex toward the apertural end, spiral suture distinct, depressed, having a scalloped pattern. Wall noncalcareous, thin, translucent, white, appears granular but has very few clearly distinguishable enclosed grains, apparently flexible in life, judging from the large proportion of distorted specimens, surface texture smooth. Aperture observed on only one specimen 
where it is an interiomarginal slit on the umbilical side extending from the periphery to about two-thirds the distance to the umbilicus.

Dimensions.-Average-size specimens have a maximum diameter, in the plane of coiling, of about $0.17 \mathrm{~mm}$, a minimum diameter of about $0.13 \mathrm{~mm}$, and a thickness parallel to the axis of coiling of about $0.05 \mathrm{~mm}$. Larger, crushed specimens attain a maximum diameter of $0.28 \mathrm{~mm}$.

Remarks.-The most distinctive characters of this species are the number of chambers, low spire, obliquity of the sutures, smoothness of the wall, and very fine grain size. The Red Bird specimens are very closely similar to examined paratypes of Trochammina ribstonensis Wickenden, except that the paratypes are filled, and thus the walls are darker in color.

The hypotype illustrated by Tappan (1962, pl. 39, figs. 15a-c) is almost certainly not this species; I am following Wall's (1967b, p. 67) example and excluding it from the synonymy.

Occurrence and range.-Trochammina ribstonensis is a distinctive species and has been widely reported from the Cretaceous of Canada and Alaska. It was originally described from a borehole in Alberta, probably from the Lea Park Formation, by Wickenden (1932, p. 90, pl. 1, figs. 12a-c). Since then, it has been reported in Canada from the lower 40 feet of the Lea Park Shale of late Santonian age in Alberta (Nauss, 1947, p. 340, pl. 49, figs. 6a-c), from the lower part of the Lea Park Formation near Lloydminster, Saskatchewan (Wickenden, 1941), from the Bearpaw Formation of middle and late Campanian and early Maestrichtian ages in southwestern Saskatchewan and southern Alberta (Loranger and Gleddie, 1953, p. 166, fig. 3), and from the early Campanian part of the Wapiabi Formation in the Rocky Mountain foothills of Canada (Wall and Germundson, 1963, p. 343; Wall, 1967a, p. 189; Wall, 1967b, p. 67, pl. 10, figs. 20-25). In Alaska, T. ribstonensis has been reported from throughout the Schrader Bluff Formation of late Santonian and Campanian ages by Tappan (1962, p. 154) and Bergquist (1966, pl. 14).

Wall (1967a, p. 189) has defined the Trochammina ribstonensis zone for the northern Rocky Mountain foothills of Alberta; it is in the upper half of the Puskwaskau or Wapiabi Formation and is of late Santonian and early Campanian ages. At Red Bird this species occurs in somewhat younger beds than cited by Wall for the northern foothills, possibly owing to different times of development of favorable environmental conditions in the two areas. Trochammina sp. cf. T. ribstonensis reported by Wall (1967a, p. $190 ; 1967 \mathrm{~b}$, p. 69$)$ is from the $T$. ribstonensis zone and is slightly different from $T$. ribstonensis $\mathrm{s}$. $\mathrm{s}$.

Trochammina of. T. wetteri Stelck and Wall

Plate 7, figures 6, 7

Trochammina wetteri Stelck and Wall, 1955, Research Council Alberta Rept. 70, p. 59, pl. 2, figs. 1-3, 6.

Wall, 1967b, Research Council Alberta Bull. 20, p. 71, pl. 8, figs. 21-26; pl. 10, figs. 7-9.

Description.-Test trochospiral to slightly streptospiral, spire generally very low and in many specimens not recognizable because of distortion; undistorted specimens unequally biconvex, spiral side being less convex than umbilical side; composed of two whorls or less, having generally four but sometimes three and sometimes five chambers in the final whorl; umbilicus lacking or very shallow; undistorted specimens very robust in shape and have a broadly rounded axial periphery and slightly lobulate equatorial periphery. Chambers slightly to moderately inflated, increasing regularly and abruptly in size as added, the greatest dimension being parallel to the axis of the test. Sutures generally not visible because of coarse wall texture, slightly to moderately depressed, straight and radial or slightly oblique in spiral and umbilical side views. Wall composed of moderate-sized to relatively coarse grains closely set in a small proportion of cement, usually with a wide range of grain sizes included, grains almost exclusively quartz, surface texture rough, color usually flat white but many specimens having yellow to brown ferruginous staining and many others appear gray or brownish gray because of dark-colored chamber fillings; chamber walls commonly flattened and test shape distorted when not filled. Aperture not positively observed on any specimen, presumably a low interiomarginal slit.

Dimensions.-Average-size undistorted specimens have a maximum diameter of about $0.52 \mathrm{~mm}$ and a minimum diameter of $0.44 \mathrm{~mm}$, measured across the spiral side through the center of the test, and a thickness parallel to the axis of coiling of about $0.40 \mathrm{~mm}$. Distorted large specimens attain maximum diameters of $1.04 \mathrm{~mm}$.

Remarks.-Characteristic features of the Red Bird specimens are the small number of abruptly enlarging chambers in the final whorl, the generally coarse grain size, and, in undistorted or slightly distorted specimens, the low trochospiral to slightly streptospiral mode of coiling. These specimens are usually distorted to some degree, and identification of individual specimens is often difficult. 
Among previously described species of Trocham mina, the Red Bird specimens most closely resemble T. wetteri Stelck and Wall. Points of resemblance are the low coil of chambers, abruptly increasing chamber size, and number of chambers in the final whorl. The major difference between the Red Bird specimens and $T$. wetteri as described and figured is in wall texture and composition. In T. wetteri the wall is fine textured and smooth, whereas in the Red Bird specimens it is medium to coarse grained and rough. The sutures, as originally illustrated and described by Stelck and Wall $(1955$, p. 59, pl. 2, figs. 1-3, 6) are curved and oblique on the spiral side, but Wall $(1967 \mathrm{~b}$, p. 71 , pl. 8, figs. 21-26; pl. 10, figs. 7-9) described the spiral side sutures as very slightly curved and illustrates them as only slightly oblique, in both respects more like the sutures in the Red Bird specimens. Variability in wall texture is observed in many species of agglutinated Foraminifera, and it may be true for T. wetteri. Until this can be satisfactorily established, the Red Bird specimens are provisionally placed in T. wetteri.

Occurrence and range.-Trochammina wetteri Stelck and Wall was originally described from Cenomanian age deposits in western Canada (Stelck and Wall, 1955). It has also been described or listed from the Santonian and early Campanian part of the Wapiabi Formation in Alberta by Wall $(1967 \mathrm{a}$, p. $190 ; 1967 \mathrm{~b}$, p. 71) and by Wall and Germundson (1963, p. 344), where it is associated with other characteristic species of the $T$. ribstonensis microfauna.

\section{Genus VERNEUILINOIDES Loeblich and Tappan, 1949}

Verneuilinoides of. V. perplexus (Loeblich)

Plate 7, figures 8,9

Verneuitina perplexa Loeblich, 1946, Jour. Paleontology, v. 20, no. 2, p. 138, pl. 22, figs. 14-16.

Verneuilinoides perplexus (Loeblich). Loeblich and Tappan, 1949, Washington Acad. Sci. Jour., v. 39, no. 3, p. 91.

Verneuilinoides cf. V. perplexus (Loeblich) Mello, 1969, U.S. Geol. Survey Prof. Paper 611, p. 46, pl. 1, figs 1a, b.

Remarks.-Although numerous specimens of this species were recovered, all are crushed or distorted to some degree. They are very clearly conspecific with specimens placed in Verneuilinoides cf. $V$. perplexus by Mello (1969, p. 46) from the Pierre Shale and Fox Hills Sandstone in South Dakota; however, fewer specimens have the untwisted or slightly twisted triserial arrangement of the early chambers, and some specimens seem to lack it altogether. Crushed paratypes of Verneuilina perplexa in the Cushman collection closely resemble the crushed Red Bird specimens, but a well-preserved paratype and the holotype have prominent untwisted or slightly twisted early triserial chamber arrangements. Present indications are that these specimens and those described by Mello (1969) from South Dakota might best be separated as a new species. For the present, the Red Bird specimens are referred to $V$. perplexus in the hope that better specimens will be forthcoming which will either permit a confident assignment to an existing species or will provide the information necessary to adequately describe a new species.

The specimens from Red Bird are clearly not the same as the paratypes in the Cushman collection of Verneuilinoides bearpawensis (Wickenden), the most commonly reported species from beds equivalent in age to the Pierre Shale, especially in terms of the rate and degree of chamber inflation and number of chambers per whorl. Verneuilinoides sp. and Verneuilinoides cf. $V$. bearpawensis, reported by North and Caldwell $(1964$, p. 15, 16) from the Lea Park Formation of Saskatchewan, may be conspecific with the Red Bird specimens, but this cannot be clearly determined from the description and figures.

Occurrence and range.-Vermeuilinoides cf. $V$. perplexus was previously recorded from the early Maestrichtian part of the Pierre Shale and Fox Hills Sandstone by Mello (1969, p. 46).

\section{Incertae sedis sp. A}

Plate 7, figure 4

Incertae sedis sp. A. Mello, 1969, U.S. Geol. Survey Prof. Paper 611, p. 101, pl. 3, figs. 1a-c.

Description.-Test single chambered, calcareous, finely perforate, radial in microstructure, circular in apertural view, apertural side generally moderately convex, opposite side very convex to subconical; some specimens spherical. Wall smooth, dull white. Aperture a small round hole in the center of the apertural surface, flush with the surface and lacks any internal extension.

Dimensions.-The Red Bird specimens attain a maximum diameter of $0.108 \mathrm{~mm}$ perpendicular to the apertural axis and $0.112 \mathrm{~mm}$ parallel to this axis.

Remarks.--None of the seven Red Bird specimens is well enough preserved to show the transparent corona about the aperture or the glassy wall described for some specimens of this species by Mello (1969, p. 101). In every other respect, including size, these specimens are exactly like those described by Mello (1969). 
Occurrence and range.-This apparently distinctive fossil, almost certainly a foraminifer but of otherwise unclear taxonomic relationships, has previously been reported from the late Campanian and early Maestrichtian part of the Pierre Shale in South Dakota (Mello, 1969, p. 101).

\section{REFERENCES CITED}

Applin, E. R., 1933, A microfossiliferous Upper Cretaceous section from South Dakota: Jour. Paleontology, v. 7, no. 2, p. 215-220.

Bandy, O. L., and Arnal, R. E., 1960, Concepts of foraminiferal paleoecology : Am. Assoc. Petroleum Geologists Bull., v. 44, no. 12, p. 1921-1932, figs. 1-14.

Belford, D. J., 1960, Upper Cretaceous Foraminifera from the Toolonga calcilutite and Gingin chalk, Western Australia: Australia Bur. Mineral Resources, Geology and Geophysics, Bull. 57, 198 p., 35 pls., 14 figs.

Bergquist, H. R., 1961, Foraminiferal zonation in Matanuska Formation, Squaw Creek-Nelchina River area, southcentral Alaska: Am. Assoc. Petroleum Geologists Bull., v. 45, no. 12, p. 1994-2011, 3 figs.

- 1966, Micropaleontology of the Mesozoic rocks of northern Alaska: U.S. Geol. Survey Prof. Paper 302-D, p. 93-227, pls. 13-24, figs. 33-49.

Bolin, E. J., 1956, Upper Cretaceous Foraminifera, Ostracoda, and Radiolaria from Minnesota: Jour. Paleontology, v. 30, no. 2, p. 278-298, pls. 37-39, 5 figs.

Brotzen, Fritz, 1948, The Swedish Paleocene and its foraminiferal fauna: Sveriges geol. undersökning, Årsb. 42, no. 2, ser. C, no. 493,140 p., 19 pls., 41 figs.

Cushman, J. A., 1944, The foraminiferal fauna of the type locality of the Pecan Gap Chalk [Texas]: Cushman Lab. Foram. Research Contr., v. 20, pt. 1, p. 1-17, pls. 1-3.

- 1946, Upper Cretaceous Foraminifera of the Gulf Coastal region of the United States and adjacent areas: U.S. Geol. Survey Prof. Paper 206, 241 p., 66 pls.

- 1948, Foraminifera, their classification and economic use [4th ed.]: Cambridge, Mass., Harvard Univ. Press, 605 p., 55 pls., 31 figs.

Cushman, J. A., and Church, C. C., 1929, Some Upper Cretaceous Foraminifera from near Coalinga : California Acad. Sci. Proc., 4th ser., v. 18, no. 16, p. 497-530, pls. 36-41.

Cushman, J. A., and Deaderick, W. H., 1942, Cretaceous Foraminifera from the Brownstown marl of Arkansas: Cushman Lab. Foram. Research Contr., v. 18, pt. 3, p. 50-66, pls. 9-15.

- 1944, Cretaceous Foraminifera from the Marlbrook marl of Arkansas: Jour. Paleontology, v. 18, no. 4, p. 328-342, pls. 50-53.

Cushman, J. A., and Jarvis, P. W., 1928, Cretaceous Foraminifera from Trinidad: Cushman Lab. Foram. Research Contr., v. 4, pt. 4, p. 85-103, pl. 12, figs. 9-11.

1929, New Foraminifera from Trinidad: Cushman Lab. Foram. Research Contr., v. 5, pt. 1, p. 6-17, pls. 2, 3.

Cushman, J. A., and Waters, J. A., 1927, Some arenaceous Foraminifera from the Upper Cretaceous of Texas: Cushman Lab. Foram. Research Contr., v. 2, pt. 4, p. 81-85, pls. $10,11$.
Eicher, D. L., 1960, Stratigraphy and micropaleontology of the Thermopolis Shale [Wyoming]: Yale Univ. Peabody Mus. Nat. History Bull. 15, 126 p., 6 pls., 12 figs.

1965, Foraminifera and biostratigraphy of the Graneros Shale: Jour. Paleontology, v. 39, no. 5, p. 875-909, pls. 103-106, figs. 1-5.

1966, Foraminifera from the Cretaceous Carlile Shale of Colorado: Cushman Found. Foram. Research Contr., v. 17, pt. 1, p. 16-31, pls. 4-6, figs. 1, 2.

- 1967, Depth in the Greenhorn Sea, in A symposium on the paleoenvironments of the Cretaceous seaway in the western interior: Golden, Colo., Colorado School Mines, p. 145-172, figs. 1-14.

Franke, Adolf, 1911, Die Foraminiferen des Unter-Eocäntones der ziegelei Schwarzenbeck: Kgl. preussische geol. Landesanst. Jahrb., v. 32, pt. 2, no. 1, p. 106-111, pl. 3.

Gill, J. R., and Cobban, W. A., 1965, Stratigraphy of the Pierre Shale, Valley City and Pembina Mountain areas, North Dakota: U.S. Geol. Survey Prof. Paper 392-A, 20 p., 7 figs. - 1966, The Red Bird section of the Upper Cretaceous Pierre Shale in Wyoming: U.S. Geol. Survey Prof. Paper 393-A, 73 p., 12 pls., 17 figs.

Jennings, P. H., 1936, A microfauna from the Monmouth and basal Rancocas groups of New Jersey: Bull. Am. Paleontology, v. 23, no. 78 , p. 1-76, 7 pls.

Jones, D. J., ed., 1953, Microfossils of the Upper Cretaceous of northeastern Utah and southwestern Wyoming: Utah Geol. and Mineralog. Survey Bull. 47, 158 p., 16 pls., 8 figs.

LeRoy, L. W., and Schieltz, N. C., 1958, Niobrara-Pierre boundary along Front Range, Colorado: Am. Assoc. Petroleum Geologists Bull., v. 42, no. 10, p. 2444-2464, figs. 1-12.

Leslie, R. J., 1965, Ecology and paleoecology of Hudson Bay Foraminifera : Canada, Bedford Inst. Oceanography, B.I.O. Rept. 65-6, 191 p., 10 pls., 36 figs.

Loeblich, A. R., Jr., and Tappan, H. N., 1950, Foraminifera from the type Kiowa Shale, Lower Cretaceous, of Kansas: Kansas Univ. Paleont. Contr., no. 6, Protozoa, art. 3, p. 1-15, pls. 1, 2.

Loeblich, A. R., Jr., Tappan, H. N., and others, 1964, Protista 2, Sarcodina, chiefly "Thecamoebians" and Foraminiferida, Part C of Moore, R. C., ed., Treatise on invertebrate paleontology: New York and Lawrence, Kans. Geol. Soc. America and Univ. Kansas Press, 2v.

Loetterle, G. J., 1937, The micropaleontology of the Niobrara formation in Kansas, Nebraska, and South Dakota: Nebraska Geol. Survey Bull. 12, 2d ser., 73 p., 11 pls., 3 figs.

Loranger, D. M., and Gleddie, Joseph, 1953, Some Bearpaw zones in southwestern Saskatchewan and southern Alberta, in Alberta Soc. Petroleum Geologists Guidebook, 3d Ann. Field Conf. and Symposium, 1953: p. 158-175, pls. 1-3, figs. 1-4.

Mello, J. F., 1969, Foraminifera and stratigraphy of the upper part of the Pierre Shale and lower part of the Fox Hills Sandstone (Cretaceous), north-central South Dakota: U.S. Geol. Survey Prof. Paper 611, 121 p., 12 pls., 14 figs.

Mellon, G. B., and Wall, J. H., 1956, Foraminifera of the upper McMurray and basal Clearwater Formations, Part 1 of Geology of the McMurray formation: Research Council Alberta Rept. 72, 43 p., 4 figs. 
Nauss, A. W., 1947, Cretaceous microfossils of the Vermilion area, Alberta: Jour. Paleontology, v. 21, no. 4, p. 329-343, pls. $48,49,3$ flgs.

North, B. R., and Caldwell, W. G. E., 1964, Foraminifera from the Cretaceous Lea Park Formation in south-central Saskatchewan: Saskatchewan Research Council, Geology Div. Rept. 5, 43 p., 4 pls., 3 figs.

Olsson, R. K., 1959, Late Cretaceous-early Tertiary stratigraphy of New Jersey [abs.]: Dissert. Abs., v. 19, no. 8, p. 2063-2064.

1960, Foraminifera of latest Cretaceous and earliest Tertiary age in the New Jersey Coastal Plain: Jour. Paleontology, v. 34, no. 1, p. 1-58, 12 pls., 2 figs.

Perlmutter, N. M., and Todd, M. R., 1965, Correlation and Foraminifera of the Monmouth Group (Upper Cretaceous), Long Island, New York: U.S. Geol. Survey Prof. Paper 483-I, 24 p., 8 pls.

Pessagno, E. A., Jr., 1967, Upper Cretaceous planktonic Foraminifera from the western Gulf Coastal Plain: Palaeontographica Americana, v. 5, no. 37, p. 245-445, pls. 48-101, figs. 1-63.

Phleger, F. B., 1960, Ecology and distribution of Recent Foraminifera : Baltimore, Johns Hopkins Press, 297 p.

Searight, W. V., 1937, Lithologic stratigraphy of the Pierre formation of the Missouri Valley in South Dakota: South Dakota Geol. Survey Rept. Inv. 27, 63 p., 8 pls.

1938, The microfauna of the Sully member of the Pierre: Iowa Acad. Sci. Proc., v. 45, p. 135-137 [1939].

Sohl, N. F., 1967, Upper Cretaceous gastropods from the Pierre Shale at Red Bird, Wyoming: U.S. Geol. Survey Prof. Paper 393-B, 46 p., 11 pls., 11 figs.

Stelck, C. R., and Wall, J. H., 1954, Kaskapau Foraminifera from Peace River area of western Canada: Research Council Alberta Rept. 68, 38 p., 2 pls., 5 figs.

1955, Foraminifera of the Cenomanian Dunveganoceras zone from Peace River area of western Canada (Alberta) : Research Council Alberta Rept. 70, 80 p., 9 pls., 6 figs.
Stelck, C. R., Wall, J. H., Bahan, W. G., and Martin, L. J., 1956, Middle Albian Foraminifera from Athabaska and Peace River drainage areas of western Canada: Research Council Alberta Rept. 75, 60 p., 5 pls. 2 figs.

Stelck, C. R., Wall, J. H., and Wetter, R. E., 1958, Lower Cenomanian Foraminifera from Peace River area, western Canada: Research Council Alberta Bull. 2, pt. 1, 35 p., 4 pls., 2 figs.

Tappan, H. N., 1957, New Cretaceous index Foraminifera from northern Alaska, in Loeblich, A. R., Jr., and others, Studies in Foraminifera: U.S. Natl. Mus. Bull. 215, p. 201-222, pls. $65-71$, fig. 29.

1962, Foraminifera from the Arctic slope of Alaska, Part 3, Cretaceous Foraminifera: U.S. Geol. Survey Prof. Paper 236-C, p. 91-209, pls. 29-58, figs. 10-18.

Wall, J. H., 1960, Upper Cretaceous Foraminifera from the Smoky River area, Alberta: Research Council Alberta Bull. 6, 43 p., 5 pls., 1 fig.

1967a, Paleoecology of Cretaceous marine microfaunas in the Rocky Mountain foothills of Alberta and British Columbia, in A symposium on the paleoenvironments of the Cretaceous seaway in the western interior: Golden, Colo., Colorado School Mines, p. 173-196, figs. 1-3.

1967b, Cretaceous Foraminifera of the Rocky Mountain foothills, Alberta: Research Council Alberta Bull. 20, 185 p., 19 pls., 4 figs.

Wall, J. H., and Germundson, R. K., 1963, Microfaunas, megafaunas, and rock-stratigraphic units in the Alberta Group (Cretaceous) of the Rocky Mountain foothills: Bull. Canadian Petroleum Geology, v. 11, no. 4, p. 327-349, 4 figs.

Wickenden, R. T. D., 1932, New species of Foraminifera from the Upper Cretaceous of the Prairie Provinces: Royal Soc. Canada Trans., 3d ser., v. 26, sec. 4, p. 85-92, 1 pl. 1941, Cretaceous marine formations penetrated in wells near Lloydminster, Saskatchewan: Royal Canadian Inst. Trans., no. 50, v. 23, pt. 2, p. 147-155.

1945, Mesozoic stratigraphy of the eastern plains, Manitoba and Saskatchewan: Canada Geol. Survey Mem. 239, Pub. 2472, 87 p., 5 pls., 2 figs. 


\section{INDEX}

[Italic page numbers indicate descriptions]

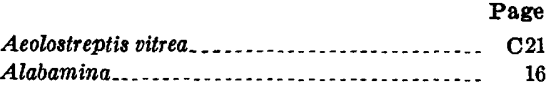
australis australis ........ 8, 10, 11, $15 ; \mathrm{pl}$. dorsoplana............................ 16 alexanderi, Proteonina....................... 36 Stilostomella............................ 45

alpha, Haplophragmoides excavata...... 32,33 ; pl. 4 Neobulimina canadensis...... 8, 10, 11, s7; pl. 6

Ammobaculites.............................. 17, 30 coprolithiforme........................ 16 coprolithiformis ........ 8, 10,11, 16, 41; pl. 1 fragmentarius......................... 17 stephensoni........................... 17 texanus.................................. 17 Ammobaculoides sp.............. 8, 10, 11, 17; pl. 1 Ammodiscus cretaceus......................... 28 kiowensis........................... 28

Anomalina.................................. 18 pinguis 17

Anomalinoides.............................. 18 pinguis ........ 8, 10, 11, 17; pl. 1 apiculata, Lagena.............. 8, 10, 11, 36; pl. 5 Oolina................................ 36 arenacea, Bathysiphon aspera, Globigerina....................... 27 Globigerinella.......................... 27 inflata, Eouvigerina.................. 25 asperus, Globigerinelloides..................... 26 Astacolus jarvisellus............. 8, 10, 11, 18; pl. 1 jarvisi ................................. 18 australis, Alabamina australis... . 8, 10, 11, 15; pl. 1 australis, Alabamina......... 8, 10, 11, 15; pl. 1

\section{B}

basiplanata, Dentalina.......... 8, 10,11, 22; pl. 2 Bathysiphon arenacea ........................ 19 brosgei.................. 8, 10,11, 18;19; pl.1 carapitanus............................ 19 eocenica vitta...................... 8, 10, 11, 19; pl. 1 bearpawensis, Verneuilinoides.............. 49 beaumontiana, Truncatulina................... 22 beaumontianus, Cibicides.......... 8, 10, 11, 2\%; pl. 2 bentonensis, Gaudryina................. 23, 24, 41 Spiroplectammina...................... 23, 24

beta, Haplophragmoides excavata...... $32,33,34 ;$ pl. 4 Neobulimina canadensis............. 8, 10,11, 38 biforaminata, Biglobigerinella................. 26 Biglobigerinella... biforaminata.............................. 26 bonanzaensis, Haplophragmoides............ 30,32 bowsheri, Psamminopelta.................... 28 brosgei, Bathysiphon .............. 8, 10,11,18, 19; pl. 1 Bulimina kickapooensis........... 8, 10,11,20; pl. 1 kickapooensis pingua................... 20 reussi navarroensis. ..................... 20

Buliminella................................. 20 carseyae................. 8, 10,11,20; pl. 1 elegantissima........................... 21 vitrea................................. 21

$\mathbf{C}$

calcula, Haplophragmoides........ . 8, 10,11,30; pl. 4 californica, Silicosigmoilina.................. 42,43

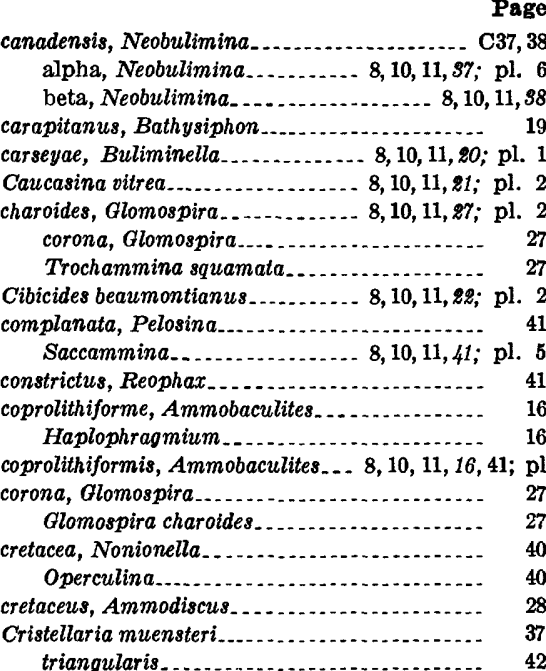

\section{D}

Dentalina basiplanata................. 8, 10,11, 22; pl. 2 gracilis..................... 8,10,11,2s; pl. 2 legumen .................... 8, 10,11, 28 ; pl. 2

depressa, Gyroidina............. 8,10,11,29; pl. 3

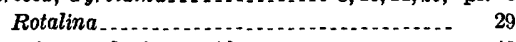
diagonis, Haplophragmoides................ 46 Trochammina............... 8, 10,11, $46 ;$ pl. 6 diffugiformis, Lagenammina...... 8, 10,11, s6; pl. 4 Proteonina........................... 36 orothia smokyensis. ............. 8, 10,11,2s; pl. 2 dorsoplana, Alabamina.................... 16

\section{$\mathbf{E}$}

elegantissima, Buliminella.................... 21 eocenica, Bathysiphon ...................... 19 Eouvigerina aspera infiata.................... 25 hispida.................................. 25 sp. $1 \ldots \ldots \ldots \ldots \ldots, 10,11,25 ;$ pl. 2

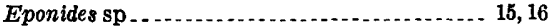
excavata, Haplophragmoides.8, 10, 11, 30, 31, 33; pl.4 alpha, Haplophragmoides. . . . ........ 32,$33 ; \mathrm{pl} .4$ beta, Haplophragmoides. . ........ . 32, 33, 34; pl. 4 emended, Haplophragmoides.............. 30,33 excavata, Haplophragmoides.............. s2; pl. 4 glabra, Haplophragmoides ............ 32, s9; pl. 4 kirki, Haplophragmoides................ 81 ; pl. 4 undifferentiated, Haplophragmoides....... $\$ 1,33$ excavata, Haplophragmoides excavata . ...... ss; pl. 4

\section{F}

Fissurina sp. A................. 8, 10, 11, 25; pl. 2 flagleri trinitatensis, Haplophragmoides........ 32 fragmentarius, Ammobaculites................ 17 fraseri, Haplophragmoides...................... 34 Frondicularia watersi............... 8, 10, 11, 25; pl. 3 futabaensis, Silicosigmoilina........ 8, 10, 11, 42; pl. 6
G

Page

Gaudryina bentonensis. .................. C23, 24,41 watersi..................... 8, 10, 11, 25; pl. 3 Gavelinella................................. 29 girardana, Gyroidina $. . . . . . . . .8,10,11,29 ; \mathrm{pl} .3$ Rotalina... 29 glabra, Haplophragmoides . .................. 30, 33, 34 glabra, Haplophragmoides excavata . . . ... 32, ss; pl. 4 Globigerina aspera........................... 27 Globigerinella aspera........................ 27

Globigerinelloides................................. 26 asperus.................................... 26 multispina............................ $\quad 26$ prairiehillensis. .............. 8, 10, 11, 26; pl. 2 globosa, Gyroidina Trochammina................. 8, 10,11, 47; pl. 6 orbicella, Gyroidina.................... 29

globulosa, Guembelina..................... 35 Heterohelix.................. 8, 10, 11,$35 ; \mathrm{pl} .5$ Textularia........................ 35

Glomospira charoides. ............. 8, 10, 11, 27; pl. 2 charoides corona........................ 27 corona............................... 27

Glomospirella............................. 28 inconstans.................. 8, 10, 11, $28 ; \mathrm{pl} 3$ umbilicata........................... 28 gracilis, Dentalina................. 8, 10,11, 28; pl. 2 gravenori, Textularia....................... 46 Guembelina globulosa . ...................... 35

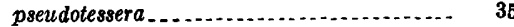
pulchra............................... 35 ultimatumida.............................. 36

Gyroidina.................................... 30 depressa . ..................... 8, 10,11, $29 ;$ pl. 3 girardana ................... 8, 10,11, $29 ; \mathrm{pl} .3$ globosa.............................. 29 orbicella $\ldots . . . . . . . . . . . . . . . . . . .29$ nitida sp. 1 . . .

H

Haplophragmium coprolithiforme............ 16 Haplophragmoides . bonanzaensis............................ 30,32 calcula ...................... 8, 10,11,30; pl. 4 diagonis . . ............................... 46 excavata................. 8, 10,11, $30,31,33 ; \mathrm{pl} .4$ alpha . . ................ 32,$33 ;$ pl. 4 beta ......................... s2, 33, 34; pl. 4 emended ........................... 30, 33 excavata.......................... $32 ;$ pl. 4 glabra............................. $32, s 9 ;$ pl. 4 kirki............................... $81 ;$ pl. 4 undifferentiated..................... 81,33 flagleri trinitatensis........................ 32 fraseri. . glabra $\ldots \ldots \ldots \ldots \ldots \ldots \ldots$ kirki............................... 30, 31, 32 sp. $1 \ldots \ldots \ldots, 10,11,34 ;$ pl. 4 sp. $2 \ldots \ldots \ldots \ldots$................. 8, 10,11, $34 ;$ pl. 4 sp. indet. . . . . . . . . . . . . . Heterohelix globulosa . . . . . . . . . . . $8,10,11,35 ;$ pl. 5 pulchra..................... 8, 10, 11, $35 ;$ pl. 5 ultimatumida............... 8, 10,11, 35, 36; pl. 5 hispida, Eouvigerina...................... 25 


\section{PLATE 1}

Figures 1-3. Alabamina australis Belford australis Belford (p. C15).

1a, b. Umbilical and spiral side views, $\times 110$, USNM 687826.

2. Edge view, $\times 148$, USNM 687828 .

3. Edge view etched to show internal structures, $\times 194$, USNM 687827 .

4. Ammobaculoides? sp. (p. C17).

Side view, $\times 112$, USNM 687830 .

5. Anomalinoides pinguis (Jennings) (p. C17).

5a-c. Spiral side, edge, and umbilical side views, $\times 148$, USNM 687831.

6. Astacolus jarvisellus Mello? (p. C18).

6a, b. Edge and side views, $\times 148$, USNM 687832.

7-9. Bathysiphon brosgei Tappan (p. C18).

7a, b. Apertural and side views, $\times 56$, USNM 687835.

8. Side view of specimen having coarse-grained wall, $\times 27$, USNM 687834 .

9. Side view of specimen having fine-grained wall, $\times 56$, USNM 687833 .

10. Bathysiphon vitta Nauss (p. C19).

Side view, $\times 88$, USNM 687836 .

11. Ammobaculites coprolithiformis (Schwager) (p. C16).

Side view, $\times 56$, USNM 687829 .

12, 13. ?Buliminella carseyae Plummer (p. C20).

12a-c. Apertural and opposite side views, $\times 88$, USNM 687838.

13. Side view partly etched to show toothplate, $\times 88$, USNM 687839.

14. Bulimina kickapooensis Cole (p. C20).

Side view, $\times 88$, USNM 687837 . 

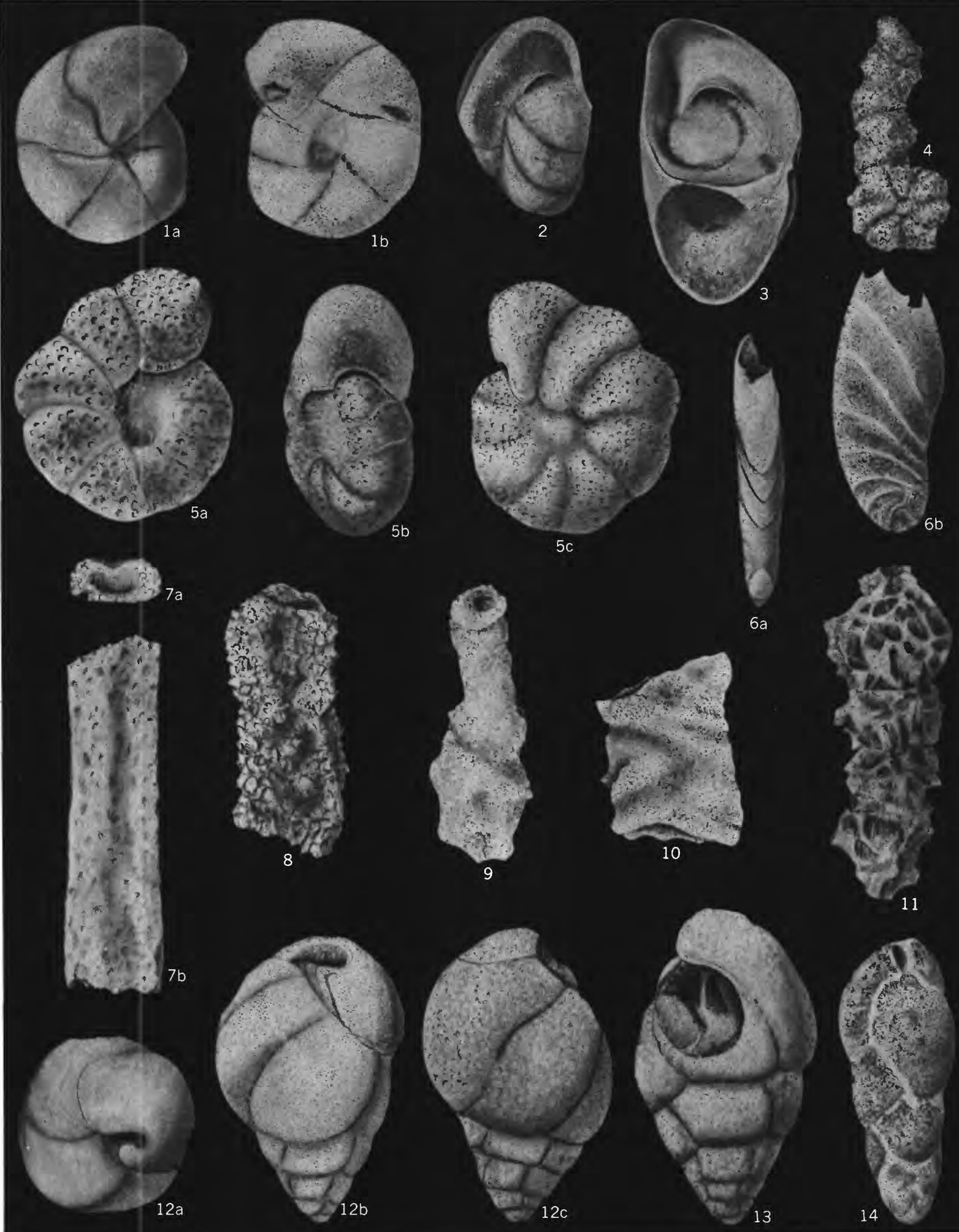

ALABAMINA, AMMOBACULITES, AMMOBACULOIDES ?, ANOMALINOIDES, ASTACOLUS, BATHYSIPHON, BULIMINA, AND ?BULIMINELLA 


\section{PLATE 2}

Frgure 1. Caucasina vitrea (Cushman and Parker) (p. C21).

$1 \mathrm{a}, \mathrm{b}$. Side views, $\times 219$, USNM 687840 .

1c Bottom view, $\times 219$, USNM 687840 .

2. Eouvigerina sp. 1 (p. C25)

2a-c. Edge, apertural, and side views, $\times$ 194, USNM 687847.

3. Cibicides sp. aff. C. beaumontianus (d'Orbigny) (p. C22).

3a-c. Spiral side, edge, and umbilical side views, $\times 112$, USNM 687841.

4. Glomospira charoides (Jones and Parker) (p. C27).

$4 \mathrm{a}, \mathrm{b}$. Top and side views, $\times 112$, USNM 687852 .

5. Globigerinelloides prairiehillensis Pessagno (p. C26).

$5 \mathrm{a}, \mathrm{b}$. Edge and side views, $\times 148$, USNM 687851.

6. Fissurina sp. A (p. C25).

6a, b. Apertural view (full lateral extent not shown) and side view, $\times 194$, USNM 687848.

7. Dentalina legumen Reuss (p. C23).

Side view, $\times 70$, USNM 687844 .

8. Dentalina basiplanata Cushman (p. C22). Side view, $\times 70$, USNM 687842 .

9. Dentalina ef. D. gracilis d'Orbigny (p. C23). Side view, $\times$ 88, USNM 687843 .

10, 11. Dorothia smokyensis Wall (p. C23).

$10 \mathrm{a}, \mathrm{b}$. Side views, $\times 56$, USNM 687845 .

11a, b. Side views, $\times 56$, USNM 687846 . 


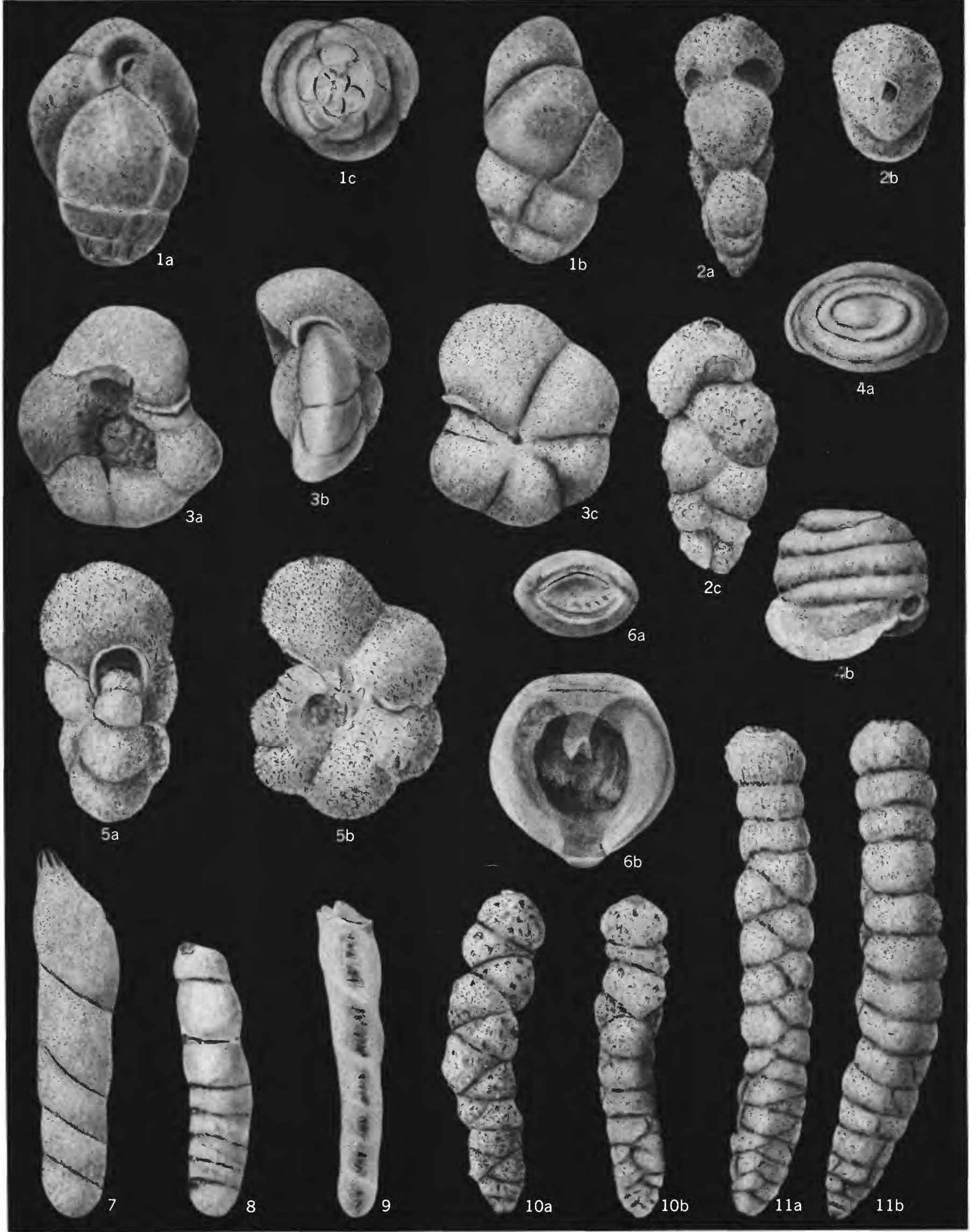

CAUCASINA, CIBICIDES, DENTALINA, DOROTHIA, EOUVIGERINA, FISSURINA, GLOBIGERINELLOIDES, AND GLOMOSPIRA 


\section{PLATE 3}

Figure 1, 2. Glomospirella inconstans Mello, n. sp. (p. C28).

1a-c. Paratype, opposite side and edge views, $\times 194$, USNM 687855.

2a-c. Holotype, opposite side and edge views, $\times 112$, USNM 687856.

3. Gaudryina watersi (Cushman) (p. C25).

$3 a, b$. Edge and side views, $\times 88$, USNM 687850 .

4. Gyroidina sp. 1 (p. C29).

4a-c. Edge, spiral side, and umbilical side views, $\times 148$, USNM 687859 .

5. Gyroidina depressa (Alth) (p. C29).

5a-c. Umbilical side, edge, and spiral side views, $\times 278$, USNM 687857 .

6. Gyroidina girardana (Reuss) (p. C29).

6a-c. Spiral side, edge, and umbilical side views, $\times 268$, USNM 687858.

7. Frondicularia watersi Cushman (p. C25).

7a, b. Edge and side views, $\times 56$, USNM 687849. 

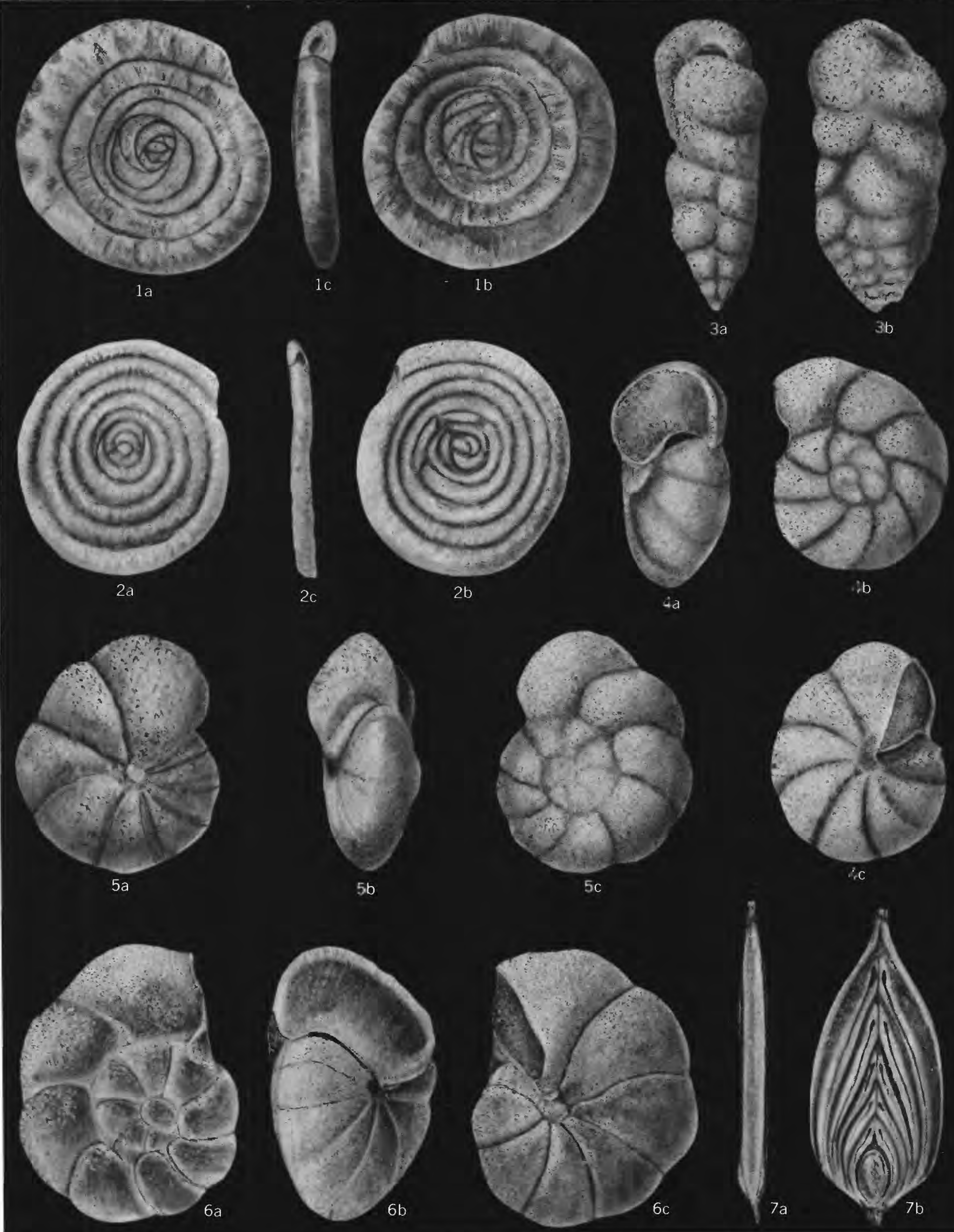

FRONDICULARIA, GAUDRYINA, GLOMOSPIRELLA, AND GYROIDINA 


\section{PLATE 4}

Frgure 1. Haplophragmoides excavata Cushman and Waters forma alpha (p. C32).

$1 \mathrm{a}, \mathrm{b}$. Side and edge views, $\times 56$, USNM 687861 .

2. H. excavata Cushman and Waters forma kirki (p. C31).

$2 \mathrm{a}, \mathrm{b}$. Side and edge views, $\times 194$, USNM 687866 .

3. H. excavata Cushman and Waters forma excavata (p. C33).

Side view, $\times 88$, USNM 687863.

4. H. excavata Cushman and Waters forma beta (p. C32).

$4 \mathrm{a}, \mathrm{b}$. Side and edge views, $\times 88$, USNM 687862 .

5. H. excavata Cushman and Waters forma glabra (p. C33). $5 a, b$. Edge and side views, $\times 112$, USNM 687865 .

6. H. excavata Cushman and Waters.

Specimen transitional between forma beta and forma excavata.

$6 a, b$. Edge and side views, $\times 56$, USNM 687864.

7. H. calcula Cushman and Waters (p. C30).

Side view, $\times 63$, USNM 687860 .

8. Haplophragmoides sp. 1 (p. C34).

$8 \mathrm{a}, \mathrm{b}$. Umbilical and spiral side views, $\times 278$, USNM 687867 .

9. Haplophragmoides sp. 2 (p. C34).

$9 \mathrm{a}, \mathrm{b}$. Side and edge views, $\times 88$, USNM 687868.

10. Lagenammina diflugiformis (H. B. Brady) (p. C36).

Side view, $\times 133$, USNM 687873.

11. Pseudobolivina! sp. 1 (p. C40).

11a, b. Edge and side views, $\times 148$, USNM 687880 . 


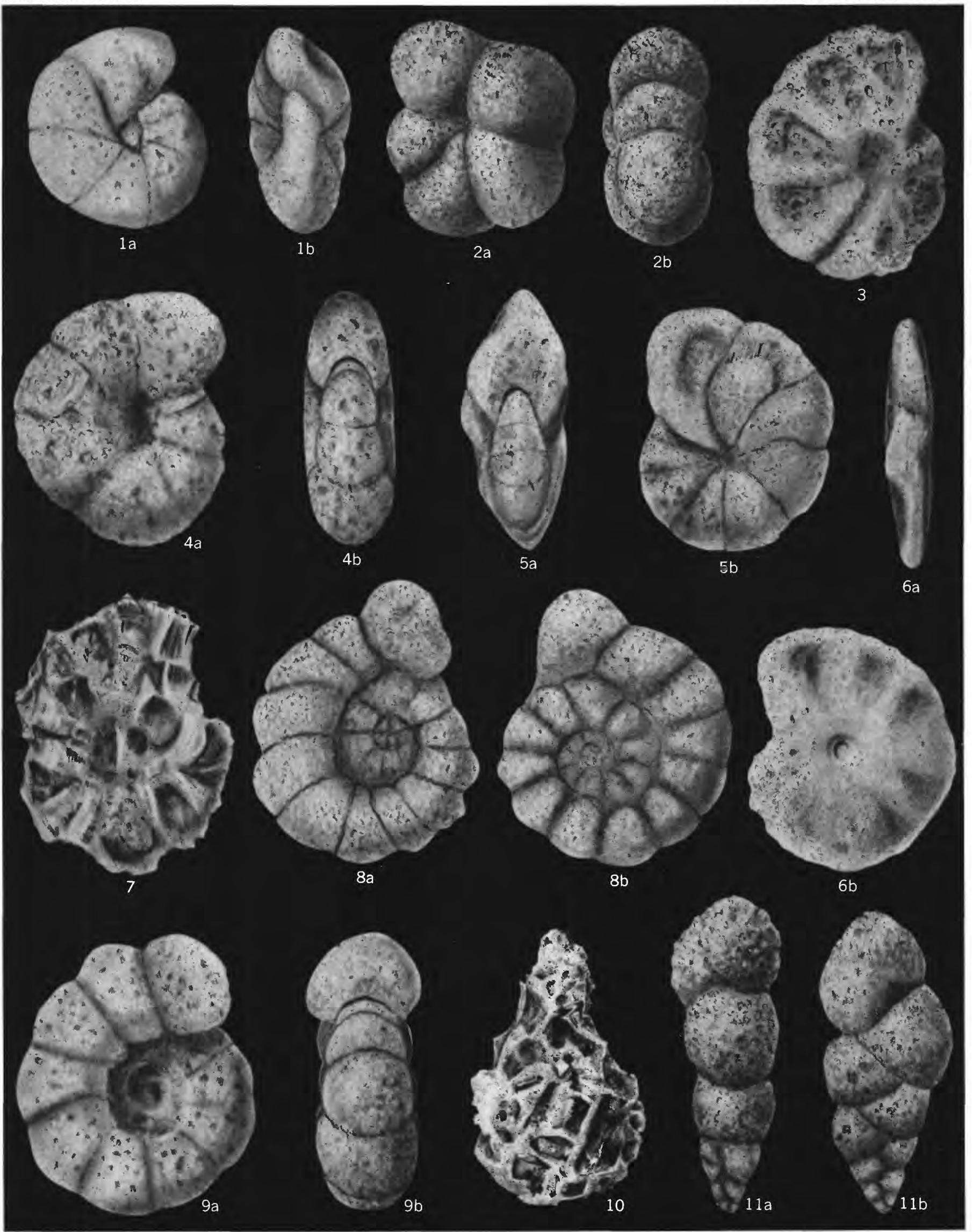




\section{PLATE 5}

Frgure 1. Lenticulina muensteri (Roemer) (p. C37).

$1 \mathrm{a}, \mathrm{b}$. Side and edge views, $\times 56$, USNM 687874.

2. Marginulina ef. M. texasensis Cushman (p. C37).

2a, b. Edge and side views, $\times 112$, USNM 687875 .

3. Lagena apiculata (Reuss) (p. C36).

Side view, $\times 140$, USNM 687872 .

4. Oolina obeliscata Mello (p. C40),

Side view, partly etched to show internal tube, $\times 185$, USNM 687879 .

5. Saracenaria triangularis (d'Orbigny) (p. C42).

$5 \mathrm{a}, \mathrm{b}$. Side and edge views, $\times 112$, USNM 687885 .

6, 7. Saccammina complanata (Franke) (p. C41).

6. Side view, $\times 56$, USNM 687883 .

$7 \mathrm{a}, \mathrm{b}$. Apertural and side views, $\times 56$, USNM 687884 .

8. Heterohelix globulosa (Ehrenberg) (p. C35).

$8 \mathrm{a}, \mathrm{b}$. Edge and side views, $\times 194$, USNM 687864 and 687869 , respectively.

9. Heterohelix cf. H. ultimatumida (White) (p. C36).

9 a, b. Edge and side views, $\times 194$, USNM 687871.

10. Heterohelix pulchra (Brotzen) (p. C35).

10a, b. Edge and side views, $\times 277$, USNM 687870.

11. Pseudoclavulina? meidamos Mello (p. C40).

11a, b. Side views, $\times 125$, USNM 687881 .

12. Reophax sp. 1 (p. C41).

Side view, $\times 50$, USNM 687882 . 


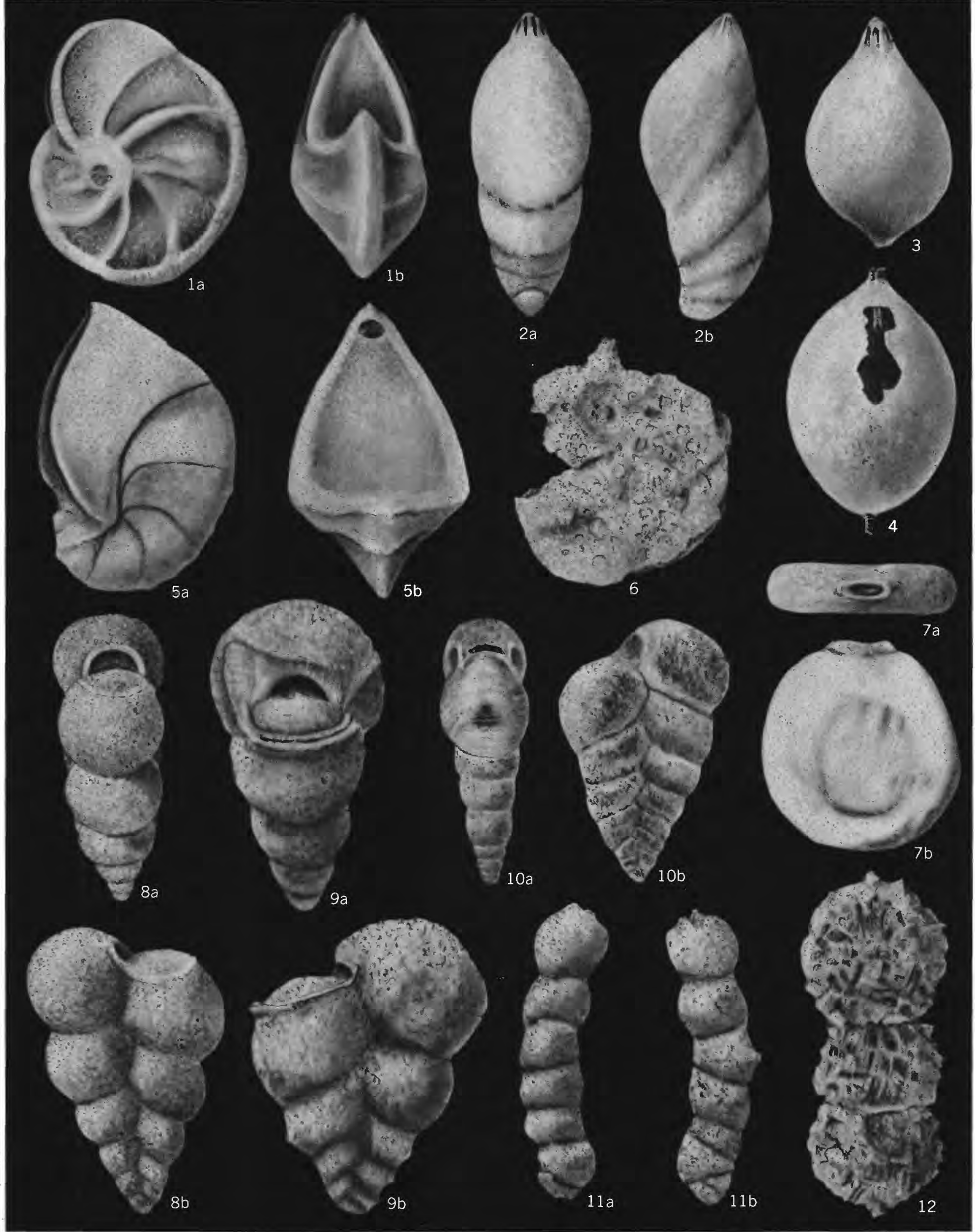

HETEROHELIX, LAGENA, LENTICULINA, MARGINULINA, OOLINA, PSEUDOCLAVULINA ?, REOPHAX, SACCAMMINA, AND SARACENARIA 


\section{PLATE 6}

Figure 1. Neobulimina canadensis Cushman and Wickenden var. alpha (p. C37).

1a-c. Opposite side and apertural views, $\times 194$, USNM 687876.

2. Neobulimina spinosa Cushman and Parker (p. C39).

2a, b. Apertural and side views, $\times 194$, USNM 687877.

3, 4. Spiroplectammina sp. 1 (p. C43).

3a, b. Apertural and side views, $\times 88$, USNM 687888 .

4a, b. Apertural and side views, $\times 112$, USNM 687887.

5. Silicosigmoilina futabaensis Asano (p. C42).

$5 \mathrm{a}, \mathrm{b}$. Apertural and side views, $\times 88$, USNM 687886.

6. Trochammina ribstonensis Wickenden (p. C47).

6a, b. Spiral and umbilical side views, $\times 300$, USNM 687895.

7. Trochammina diagonis (Carsey) (p. C4i).

$7 \mathrm{a}, \mathrm{b}$. Umbilical and spiral side views, $\times 88$, USNM 687892 .

8. Trochammina globosa Bolin (p. C47).

$8 \mathrm{a}-\mathrm{c}$. Umbilical side, edge, and spiral side views, $\times 88$, USNM 687893. 


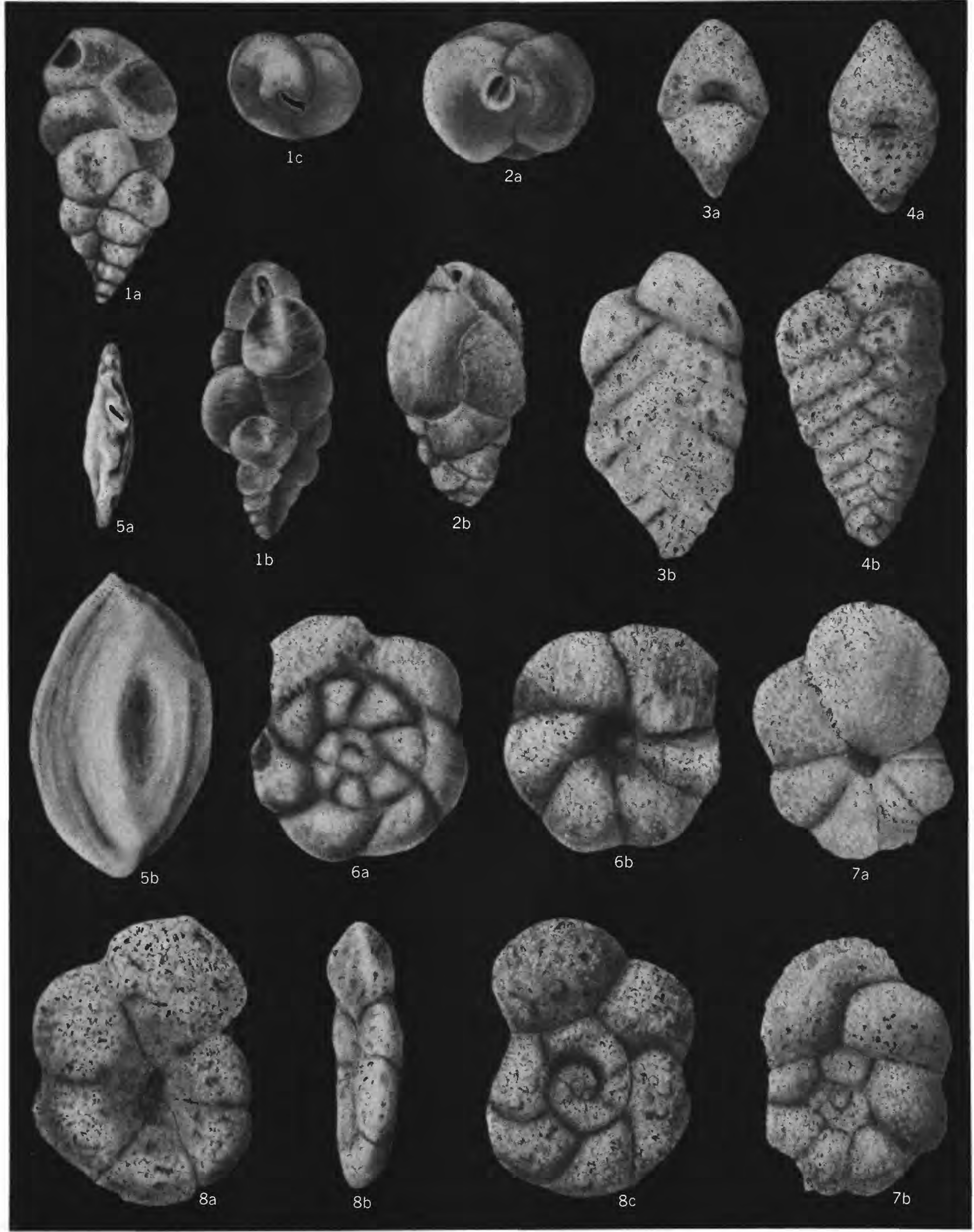




\section{PLATE 7}

Frgure 1-3. Stilostomella sp. 1 (p. C45).

1a, b. Apertural and side views, $\times 194$, USNM 687894 .

2a, b. Apertural and side views, $\times 112$, USNM 687889 .

3. Side view, $\times 120$, USNM 687890 .

4. Incertae sedis sp. A (p. C49).

$4 a$, b. Top and side views, $\times 270$, USNM 687900 .

5. Textularia sp. 1 (p. C45).

5a, b. Edge and side views, $\times 194$, USNM 687891.

6, 7. Trochammina cf. T. wetteri Stelck and Wall (p. C48).

6. Spiral side view, $\times 88$, USNM 687896.

7a-c. Spiral side, edge, and umbilical side views, $\times 88$, USNM 687897 .

8, 9. Verneuilinoides cf. V. perplexus (Loeblich) (p. C49).

$8 \mathrm{a}, \mathrm{b}$. Side views, $\times 190$, USNM 687899.

9. Side view, $\times 112$, USNM 687898.

10. Nodosaria obscura Reuss (p. C39).

10a, b. Apertural and side views, $\times 88$, USNM 687878 . 


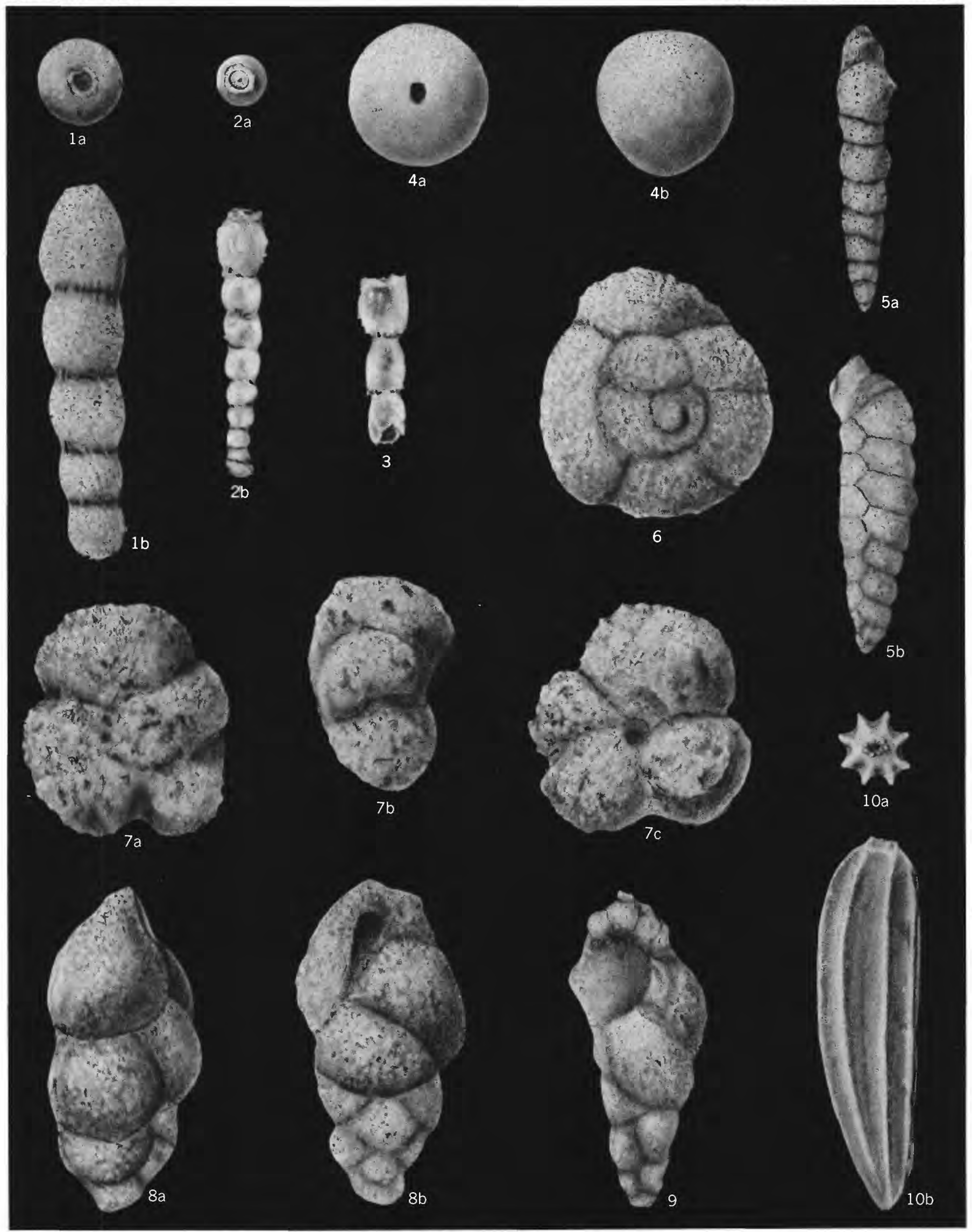

NODOSARIA, STILOSTOMELLA, TEXTULARIA, TROCHAMMINA, VERNEUILINOIDES, AND INCERTAE SEDIS 
4 